\title{
Structure and function of -glucan debranching enzymes
}

\author{
Møller, Marie Sofie; Henriksen, Anette; Svensson, Birte
}

Published in:

Cellular and Molecular Life Sciences

Link to article, DOI:

10.1007/s00018-016-2241-y

Publication date:

2016

Document Version

Peer reviewed version

Link back to DTU Orbit

Citation (APA):

Møller, M. S., Henriksen, A., \& Svensson, B. (2016). Structure and function of -glucan debranching enzymes. Cellular and Molecular Life Sciences, 73(14), 2619-2641. https://doi.org/10.1007/s00018-016-2241-y

\section{General rights}

Copyright and moral rights for the publications made accessible in the public portal are retained by the authors and/or other copyright owners and it is a condition of accessing publications that users recognise and abide by the legal requirements associated with these rights.

- Users may download and print one copy of any publication from the public portal for the purpose of private study or research.

- You may not further distribute the material or use it for any profit-making activity or commercial gain

- You may freely distribute the URL identifying the publication in the public portal

If you believe that this document breaches copyright please contact us providing details, and we will remove access to the work immediately and investigate your claim 


\title{
Structure and function of $\alpha$-glucan debranching enzymes
}

Marie Sofie MØLLER ${ }^{1,2}$, Anette HENRIKSEN ${ }^{3}$, Birte SVENSSON ${ }^{1}$

${ }^{I}$ Enzyme and Protein Chemistry, Department of Systems Biology, Technical University of Denmark, DK-2800 Kgs. Lyngby, Denmark.

${ }^{2}$ Center for Molecular Protein Science, Department of Chemistry, Lund University, 22100 Lund, Sweden. ${ }^{3}$ Department of Large Protein Biophysics and Formulation, Global Research Unit, Novo Nordisk A/S, Novo Nordisk Park, DK-2760 Måløv, Denmark

Corresponding author: Marie Sofie Møller, mariesofiemoller@gmail.com

\begin{abstract}
$\alpha$-glucan debranching enzymes hydrolyse $\alpha-1,6$-linkages in starch/glycogen, thereby playing a central role in energy metabolism in all living organisms. They belong to glycoside hydrolase families GH13 and GH57 and several of these enzymes are industrially important. Nine GH13 subfamilies include $\alpha$-glucan debranching enzymes; isoamylase and glycogen debranching enzymes (GH13_11); pullulanase type I/limit dextrinase (GH13_12-14); pullulan hydrolase (GH13_20); bifunctional glycogen debranching enzyme (GH13_25); oligo- and glucan-1,6- $\alpha$-glucosidases (GH13_31); pullulanase type II (GH13_39); and $\alpha$-amylase domains (GH13_41) in two-domain amylase-pullulanases. GH57 harbours type II pullulanases. Specificity differences, domain organisation, carbohydrate binding modules, sequence motifs, three-dimensional structures and specificity determinants are discussed.

The phylogenetic analysis indicated that GH13_39 enzymes could represent a "missing link" between the strictly $\alpha-1,6$-specific debranching enzymes and the enzymes with dual specificity and $\alpha-1,4$-linkage preference.
\end{abstract}

Keywords: Substrate specificity; glycoside hydrolase family 13 subfamilies, domain architecture; multidomain three-dimensional structure; sequence motifs and determinants; structure-function relationship; carbohydrate binding modules; phylogeny.

Abbreviations: CAZy, Carbohydrate-Active enZymes; CBM, carbohydrate binding module; CD, cyclodextrin; CDD, conserved domain database; GDE, glycogen debranching enzyme; GH, glycoside hydrolase; GHx, glycoside hydrolase family x; GH13_x, glycoside hydrolase family 13 subfamily x; ISA, isoamylase; PULI, type I pullulanase; PULII, type II pullulanase; PULII_I, type II pullulanase with one catalytic domain; PULII_II, type II pullulanase with two catalytic domains; SBS, starch binding site; SEX4, starch-excess protein-4.

Running title: $\alpha$-glucan debranching enzymes 


\section{Introduction}

$\alpha$-glucan debranching enzymes are an important group of glycoside hydrolases playing a role in the energy metabolism of all living organisms by hydrolysis of $\alpha-1,6$-glucosidic linkages in $\alpha$-glucans. The term $\alpha$ glucans here refers to polysaccharides consisting of glucose units connected by $\alpha-1,4$-glucosidic linkages and which can contain $\alpha-1,6$-branch points. Amylopectin and glycogen are the dominating branched $\alpha$-glucans in living organisms, while the linear pullulan molecule produced by the fungus Aureobasidium pullulans resembles the branched $\alpha$-glucans as it consists of $\alpha-1,4$-linked maltotriose repeats connected by $\alpha-1,6$ linkages (Fig. 1) [1]. Amylopectin, the major component of starch, is made up of hundreds of shorter $\alpha-1,4-$ glucan chains connected by $\alpha-1,6$-branch points. Amylopectin is organised together with amylose, an essentially linear $\alpha$-glucan, in the semi-crystalline starch granules (see [2] for a recent review on starch). Glycogen is the animal, fungal and bacterial counterpart to amylopectin, but is more extensively branched [3].

Starch and glycogen constitute the major energy source and storage in higher plants and microorganisms/animals, respectively. Generally, $\alpha$-glucans are degraded in a series of reactions catalysed by several enzymes hydrolysing either $\alpha-1,4$ - and/or $\alpha$-1,6-glucosidic linkages. $\alpha$-1,6-linkages are hydrolysed by glycogen debranching enzymes (GDEs; EC 3.2.1.68 and 3.2.1.33), isoamylases (ISAs; EC 3.2.1.68), and type I pullulanases (PULIs; EC 3.2.1.41) (Table 1). Furthermore, type II pullulanases (PULII; also known as amylopullulanases) show $\alpha$-glucan debranching activity along with endo- $\alpha-1,4$-glucan hydrolase ( $\alpha$-amylase) activity (EC 3.2.1.1 and 3.2.1.41), i.e. they hydrolyse both $\alpha$-1,4- and $\alpha-1,6$-linkages in $\alpha$-glucans (Table 1). In addition to these classical $\alpha$-glucan debranching enzymes, we will briefly cover the so-called oligo- and glucan-1,6- $\alpha$-glucosidases (EC 3.2.1.10), hydrolysing $\alpha$-1,6-linkages in isomaltooligosaccharides and dextran - an essentially linear $\alpha$-1,6-glucan, together with the pullulan hydrolases (EC 3.2.1.133 and 3.2.1.135), catalysing hydrolysis of $\alpha-1,6-$ and/or $\alpha-1,4$-glucosidic linkages in pullulan and starch.

The present review has emphasis on structure-function relationships, protein sequences and structural features important for substrate specificity of $\alpha$-glucan debranching enzymes. This includes an overview of the modular architecture and detailed reports on catalytic domains and carbohydrate binding modules (CBMs) of different enzymatically characterised and structure-determined $\alpha$-glucan debranching enzymes. A bioinformatics analysis covers conserved regions shared among all the glycoside hydrolase family 13 (GH13) and GH57 enzymes, and signature sequence regions that distinguish specific classes of $\alpha$-glucan debranching enzymes.

\section{Classification of $\alpha$-glucan debranching enzymes}

$\alpha$-glucan debranching enzymes belong to two glycoside hydrolase families, GH13 and GH57, according to the Carbohydrate Active Enzymes (CAZy) database classification system (http://www.cazy.org/) that assigns enzymes and CBMs into families sharing structural fold and stereochemistry of the catalytic mechanism. The classification is based on the protein sequence [4]. 
GH13, also known as the $\alpha$-amylase family, is one of the largest GH-families in CAZy with more than 28,300 protein sequences. GH13 features 22 different substrate specificities involving $\alpha$-glucosidic linkages including hydrolases, transglucosidases and isomerases [5]. Overall, GH13 members have very limited sequence similarity. Thus, only four short sequence regions are conserved (see below), and different substrate specificities can have different signature motifs [6]. All GH13 enzymes are retaining enzymes and have a catalytic TIM barrel $\left((\beta / \alpha)_{8}\right.$-barrel $)$ domain [7] with three invariant catalytic site residues: Asp (nucleophile/base), Glu (proton donor) and an Asp participating in distortion and stabilisation of the transition state. GH13 has been divided into subfamilies using a combination of cluster analysis, sequence similarity and phylogeny that reflect correlation of protein sequences and substrate specificities [5]. The $\alpha$-glucan debranching catalytic domains occur in eight GH13 subfamilies (Table 1): GH13_11, ISAs and GDEs; GH13_12-14, PULIs; GH13_20, pullulan hydrolases; GH13_25, bifunctional GDEs from eukaryotes; GH13_31, oligo- and glucan-1,6- $\alpha$-glucosidases; and GH13_39, PULIIs from extremophiles; while GH13_41 contains $\alpha$-amylase domains of amylase-pullulanases (see below) having two separate catalytic domains of which the pullulanase domains belong to GH13_12 and 14 or are not yet assigned to a subfamily. Crystal structures are available for the mentioned subfamilies except GH13_25, GH13_39, and GH13_41 (Table 1).

The enzyme specificities of GH57 include $\alpha$-amylase, amylopullulanase (PULII), branching enzyme, 4- $\alpha$ glucanotransferase, and $\alpha$-galactosidase [8]. Currently, GH57 includes 1345 members from archaea (1/4) and bacteria (3/4) (mostly extremophiles) [4]. Not all members are expected to be active enzymes, since some of the sequences lack one or both catalytic residues [9]. GH57 enzymes representing the different enzyme specificities have been biochemically characterised [8]. Among these are several PULIIs (see section below). Four GH57 enzymes have been structure determined (an $\alpha$-amylase, a 4- $\alpha$-glucanotransferease, and two branching enzymes) [4]. A fifth enzyme referred to as a GH57 maltose-forming $\alpha$-amylase has been structure determined (PDB entry 4CMR) [10], however it is non-classified in CAZy [4]. The GH57 enzymes have a catalytic $(\beta / \alpha)_{7}$-barrel domain and use a retaining mechanism with Glu and Asp as nucleophile/base and proton donor, respectively $[11,12]$. The sequences show five conserved regions, and it has been suggested to subdivide GH57 to reflect enzyme specificities [11, 13, 14]. A search in the conserved domain database (CDD) [15] including all full-length GH57 protein sequences (1283) gave 383 with a PULII domain (domain classification in CDD: GH57N_APU, sequence cluster: cd10796 and domain: GH57N_APU_like_1, sequence cluster cd10797), therefore they most likely have PULII specificity.

\section{Isoamylases and glycogen debranching enzymes}

\section{GH13_11 enzymes}

A large diversity is found within the subfamilies of GH13. This is particularly true for GH13_11 that is formed by a very diverse group of $\alpha$-glucan debranching enzymes and GH13_11 has been suggested to be further subdivided. The specificities in GH13_11 are ISAs and GDEs hydrolysing $\alpha$-1,6-branch points in amylopectin, glycogen, and products thereof generated by the action of $\beta$-amylase ( $\beta$-limit dextrins) [16]. Unlike 
pullulanases, enzymes in GH13_11 do not hydrolyse $\alpha$-1,6-glucosidic linkages in pullulan, but require an $\alpha$ 1,6-linked branch on an $\alpha-1,4$-glucan main chain for activity. ISAs from plants, algae and the Gram-negative soil bacterium Pseudomonas amyloderamosa often encode more than one isoform which may operate in multimeric complexes composed of different ISA isoforms [17, 18]. The GDEs are widespread among bacteria and an $\alpha$-helix (helix 4) situated near the active site can serve as a useful signature to distinguish GDEs from ISAs and pullulanases [19]. Furthermore, a loop (loop 4) might define substrate preference; thus a short loop 4 is associated with preference for limit dextrins, while a longer loop 4 indicates specificity for larger branched $\alpha$-glucans $[17,20]$. This feature, however, might not adequately capture ISAs and GDEs, as variation in loop 4 length is observed among ISA isoforms from the same organism [17].

\section{GH13_11 structures}

Four GH13_11 enzymes are structure-determined (Table 1): ISAs from a bacterium; Pseudomonas amyloderamosa (UniProt P10342) and a eukaryote; Chlamydomonas reinhardtii (GenBank AAP85534), and GDEs from Escherichia coli and Sulfolobus solfataricus. Five more GH13_11 members have been enzymatically characterised: GDEs from Sulfolobus acidocaldarius (BAA11864) [21], Sulfolobus shibatae (AAM81590) [22], Corynebacterium glutamicum (BAB99500) [23] and Flavobacterium sp. (AAB63356) [24], and an ISA from Oryza sativa (BAA29041) [25].

The GH13_11 crystal structures display the same overall multimodular organisation: an N-terminal carbohydrate-binding module family 48 (CBM48) (see section below), the catalytic domain, and a C-terminal $\beta$-sandwich domain (Fig. 2). Most GH13 enzymes contain this C-terminal $\beta$-sandwich domain. Its function in relation to debranching is unknown, but C-terminal domains in other GH13 enzymes e.g. GH13 branching enzymes, are shown to be involved in substrate binding $[6,26,27]$ and/or shielding hydrophobic residues of the catalytic domain from solvent contacts [28]. In GH13_11 ISA from Chlamydomonas reinhardtii the Cterminal domain participates in dimerization [16].

The GH13_11 crystal structures illustrate structural and substrate specificity diversity within GH13_11 [19, 29, 30]. Noticeably, they show different oligomerization states: Pseudomonas amyloderamosa and Chlamydomonas reinhardtii ISAs being a functional $\alpha$-1,6-glucosidase monomer and dimer, respectively. Oligomerisation is also important for activity of Sulfolobus solfataricus GDE, that has both $\alpha-1,6$-glucosidase and $\alpha-1,4$-transferase activity, where the latter is related to the oligomerisation state, since the tetramer showed $\alpha-1,4$-transferase activity, while the dimer did not [30].

The crystal structure of Chlamydomonas reinhardtii in complex with maltoheptaose (PDB entry 4OKD) revealed the presence of two surface binding sites (1 and 2), which are non-catalytic carbohydrate binding sites found on the surface of the catalytic domain that interact with sugar rings via stacking interactions with aromatic residues [31]. These sites, are located at the reducing end of the active site cleft and at the interface of the catalytic and C-terminal domains [16]. The two tryptophans forming surface binding site 1 (Trp757 and Trp 767) are conserved in all GH13_11 protein sequences based on a multiple sequence alignment of catalytic domains, while surface binding site 2 (His794, Trp652 and Trp856) is not conserved. 


\section{GH13_25 glycogen debranching enzymes}

The GH13_25 GDEs are eukaryotic [4], bifunctional enzymes exhibiting both transferase (EC 2.4.1.25) and glucosidase (EC 3.2.1.33) activities [32] residing in two separate active sites. The reactions are thought to be channelled from one active site to the other: First, a maltosyl or maltotriosyl residue from a glycogen branch is transferred to the main chain by the transferase active site exposing an $\alpha-1,6$-glucosyl stub that in turn is cleaved off at the glucosidase active site. The transferase reaction is retaining, while the glucosidase reaction is inverting $[33,34]$. There is no published structure of a GH13_25 GDE, but the transferase part of the enzymes is predicted to belong to the GH13 $(\beta / \alpha)_{8}$-barrel catalytic domain fold and have the three invariant GH13 catalytic site residues [34]. The glucosidase part has been classified into GH133, a subfamily of inverting $\alpha-1,6$-glucosidases [4]. The enzymes from the other GH13 subfamilies included here and from GH57 are all retaining enzymes. Hence GH13_25 GDEs belong to a highly specialised and atypical group of $\alpha$ glucan debranching enzymes. Due to the different characteristics mentioned above and lack of a 3D structure, this review will not cover GH13_25 in detail.

\section{Pullulanases}

Pullulanases are important industrial enzymes (see the section below on application), which motivated characterisation of a large number of pullulanases (see Tables S1 and S2 for tables with specific activity and kinetic parameters of pullulanases). An immense amount of published data includes enzymes characterised at the protein level to be pullulanases, but which have no published protein sequence. Enzymes without sequence information, however, have not been included in the present review.

Pullulanases are classified as type I (PULI) and type II (PULII) depending on the specificity. PULIs hydrolyse $\alpha$-1,6-branch linkages in amylopectin, $\beta$-limit dextrin derived from amylopectin, and pullulan. Some PULIs also have low activity on glycogen (Tables S1 and S2). By contrast PULIIs hydrolyse both $\alpha-1,4-$ and $\alpha$-1,6-glucosidic linkages in starch and pullulan, albeit some PULIIs only hydrolyse one of the linkage types in pullulan. PULIIs form two subgroups; one with one catalytic domain hydrolysing both bond types, and another having two catalytic domains, one being an $\alpha$-amylase domain that hydrolyses $\alpha-1,4$-linkages, and one PULI domain hydrolysing $\alpha$-1,6-linkages. It has been suggested to formally divide PULIIs into these subgroups [35], but lack of general acceptance renders PULII literature confusing with regard to characteristic general and specialised PULII features. PULIIs are also called amylo- or amylase-pullulanases, which appears appropriate for the two-domain PULIIs, but amylase-pullulanase has been used for both PULII types. Here, we refer to PULIIs having one and two catalytic domains as PULII_I and PULII_II, respectively. In CAZy, the different pullulanases have EC number 3.2.1.41, but where dual-bond type specificity is shown the $\alpha$ amylase EC 3.2.1.1 is also given. Thus, the PULII_IIs may get typecast in GH13 both as a pullulanase and an amylase subfamily member [4]. 
In summary, pullulanases are found in five different GH13 subfamilies $(12,13,14,39$, and 41) and in GH57. The PULIs, i.e. enzymes with $\alpha-1,6$-activity only, are in subfamilies GH13_12-14, while PULIIs cleaving both $\alpha-1,4-$ and $\alpha-1,6$-glucosidic linkages are found in all five GH13 subfamilies and in GH57.

\section{Type I pullulanases}

Pullulanases from firmicutes, especially streptococci, generally belong to GH13_12, while GH13_13 contains pullulanases from plants (eukaryotes) and bacteria mainly found in soil and water, including photosynthetic bacteria. Plant pullulanases are historically called limit dextrinases, referring to their substrate preference for limit dextrins, the hydrolysis products of amylopectin, over amylopectin. GH13_13 appears as a branch between two GH13_14 branches of the phylogenetic tree of the GH13 subfamilies reflecting that these subfamilies are closely related, but distinct. The main difference between them is in the length of three loops [5]. GH13_14 contains pullulanases from a range of bacteria, including bacilli. Besides the variations in loop lengths and additional inserts (see below), which are mainly phylogenetic issues, major differences between the three pullulanase subfamilies appear in the auxiliary domains associated with the catalytic domains. These differences together with other small differences in the catalytic domains reflect individual substrate preferences (Tables S1 and S2).

\section{Pullulanase type I structures}

Only PULIs are represented by crystal structures (Table 1). Despite the overall high structural similarity among the multi-domain GH13_12-14 PULIs (Fig. 2), sequence identities and similarities of pullulanases are low even for the catalytic domains. Accordingly, the GH13_12-14 enzymes differ in substrate specificity and preferences. In addition to the catalytic $(\beta / \alpha)_{8}$-barrel characteristic of GH13 [7], the typical pullulanase architecture has one or more $\mathrm{N}$-terminal domains, including CBMs (see below) and a C-terminal domain common for most GH13 enzymes (see above). These auxiliary domains are associated with specificity differences between the three PULI GH13 subfamilies. Unfortunately, one or more N-terminal domains are missing from some of the GH13_12 and GH13_14 structures (Fig. 2). Recently, the first structure has been determined of a branched substrate in complex with a PULI, namely barley limit dextrinase (PDB entry 4J3W, Table 2) [36].

\section{Type II pullulanases}

PULIIs are a very diverse group of enzymes with regard to enzymatic properties (see [37] for a comprehensive review). The PULIIs are multi-modular GH13 and GH57 enzymes having one or more CBMs in addition to the catalytic domain(s). PULIIs are not straightforward to classify in the CAZy GH13 subfamily system. In some cases, a PULII_II is assigned both to a PULI subfamily (GH13_12-14) and an $\alpha$-amylase subfamily. Some PULII_Is were assigned their own subfamily, GH13_39, and very recently, 44 PULII_IIs are classified in GH13_41 governed by their amylase domain together with 11 subfamily members, having only an amylase domain. Of these PULII_IIs the pullulanase domain in 34 sequences is classified in GH13_12, and in 2 
sequences in GH13_14, while 8 were not assigned to a GH13 subfamily. The majority of the GH13_12+41 PULII_IIs are from Streptococcus suis strains.

Enzymatic properties are only reported for four PULIIs from GH13_12-14: one PULII_I from Lactobacillus plantarum (GH13_14; BAF93906) [38, 39], and PULII_IIs from Streptococcus suis (GH13_12; CAR47543; only the amylase domain was characterised), Bifidobacterium breve (GH13_14 and GH13_32; AAY89038) and Bacillus sp. KSM-1378 (GH13_12 and GH13_41; AAS36537) [40-42]. Very recently an $\alpha-$ glucan debranching enzyme from an uncultured bacterium originating from the gut of Hermetia illucens has been characterised [43]. It is partially sequenced (GenBank AGL50935), and proposed to be a PULII_II based on the enzymatic characterisation and CDD information [15, 43]. Its amylase domain is classified into the $\alpha$ amylase subfamily GH13_28, while the pullulanase domain is not in a subfamily [4]. Finally, another characterised $\alpha$-glucan debranching enzyme from Thermococcus kodakarensis (BAD85166) was not classified to a GH13 subfamily [4]. It was previously referred to as a PULII [44], but recently suggested to be a pullulan hydrolase type III (see below) [45].

GH13_39 is a small PULII subfamily of 62 full-length protein sequences from bacteria, mainly thermophiles. They have a single catalytic site as based on a CDD search for hydrolysing both $\alpha-1,4-$ and $\alpha-$ 1,6-linkages [15]. GH13_39 enzymes, however, are not uniform with regard to number and types of domains additional to the GH13 catalytic domain (see section on CBMs below). Interestingly, very recently six protein sequences having both a GH13 and a GH77 catalytic domain (GH77 harbours to specificities: amylomaltase and 4- $\alpha$-glucanotransferase) were added to GH13_39 [4]. This novel type of proteins has not yet been characterised. No GH13_39 PULIIs structure is available, but GH13_39 enzymes from Alicyclobacillus, Bacillus, Geobacillus, Thermoanaerobacter and Thermoanaerobacterium have been characterised [46-58]. For some of these the substrate bond specificity is not definite. Some are referred to as a "high-molecular amylase" in older literature, although they all hydrolyse both pullulan and starch. GH13_39 from Alicyclobacillus (ADZ99363) is described as an $\alpha$-amylase [47]. PULII_I from Geobacillus thermoleovorans is one of the best-characterised GH13_39 members. It releases maltose, maltotriose and maltotetraose from soluble starch, glycogen, amylose and amylopectin, but only maltotriose from pullulan. Moreover, maltotriose and maltose were end-products of maltopentaose hydrolysis [51]. The PULII_Is from Bacillus sp. XAL601, Thermoanaerobacterium saccharolyticum and Thermoanaerobacter pseudoethanolicus released maltose, maltotriose, and maltotetraose from starch, but only maltotriose from pullulan [48, 53, 55]. Mutational analysis confirmed that the Thermoanaerobacter pseudoethanolicus enzyme has a single catalytic site responsible for both $\alpha-1,4-$ and $\alpha-1,6-$ linkage specificity [54].

Generally, PULII_Is are only able to hydrolyse pullulan $\alpha$-1,6-linkages, while PULII_IIs can hydrolyse both $\alpha-1,4-$ and $\alpha-1,6$-linkages in pullulan [38, 39, 48, 51, 53]. However, PULII_I from Anoxybacillus sp. SK3-4 (GenBank EPZ37192) is an exception, since the degradation products from pullulan is a mix of glucose, maltose, and maltotriose [59], and the enzyme has not been included in CAZy. It preferably cleaves $\alpha-1,6$ rather than $\alpha-1,4$-glucosidic bonds in pullulan [59]. 
GH57 PULII_Is have been characterised from several extreme thermophilic archaea: Caldivirga [60], Pyrobaculum [61], Pyrococcus [62], Sulfolobus acidocaldarius [63], Staphylothermus [64], and Thermococcus [45, 65-67]. None of these GH57 PULII_I members have been structure-determined, but they are predicted to have a single catalytic site with dual specificity for $\alpha-1,4-$ and $\alpha-1,6$-linkages, and no known CBMs associated with the catalytic domain $[4,15]$. However, a CDD-search with the characterised GH57 PULII_Is indicated the presence of several additional domains [15]. Remarkably, Thermococcus siculi PULII_I is suggested to possess two CBM9-like domains usually found at the C-terminus of xylanases [67].

\section{GH13_20 - Maltogenic $\alpha$-amylases, neopullulanases, and cyclomaltodextrinases}

At least 29 GH13_20 members have been characterised. They cover different substrate and linkage specificities and include maltogenic $\alpha$-amylase (EC 3.2.1.133), neopullulanase (EC 3.2.1.135), and cyclomaltodextrinase (EC 3.2.1.54) (see [68] for a comprehensive review). There seems not to be any consensus in the naming of GH13_20 enzymes which in the literature appears as being close to anarchistic. Lee et al. suggested that the above three groups of GH13_20 enzymes should be perceived as one, because they are not sufficiently different to keep individual names and enzyme codes [69].

Generally, the major substrates for GH13_20 are cyclodextrins (CD; cyclic $\alpha$-1,4-linked glucose oligosaccharides), pullulan and starch. GH13_20 enzymes hydrolyse $\alpha$-1,4- and $\alpha$-1,6-glucosidic linkages, but not necessarily equally well. The maltogenic $\alpha$-amylases prefer CDs and hydrolyse $\beta$-CDs (seven glucose units) $\sim 100$ times faster than starch or pullulan [70]. Their main product from hydrolysis is maltose. By contrast, GH13 $\alpha$-amylases having strict endo-activity towards $\alpha$-1,4-linkages cannot hydrolyse CDs or pullulan. GH13_20 maltogenic amylase moreover attacks $\alpha$-1,4- much more efficiently than $\alpha$-1,6-linkages [71]. Most of the characterised GH13_20 enzymes catalyse transglucosylation besides their glucosidase activity [68]. One of the outliers among the characterised GH13_20 enzymes is the structure-determined Nostoc punctiforme enzyme, which prefers longer malto-oligosaccharides (>G8) and performs hydrolysis without transglucosylation or CD-hydrolysing activities common for the GH13_20 enzymes [72]. Dimerisation has been shown for a number of GH13_20 enzymes to be indispensable for activity [69, 72-75] and some exist in a monomer/dimer equilibrium in solution [68].

GH13_20 enzymes are also called pullulan hydrolases and divided into groups depending on specificity: Pullulan hydrolases types I and II only hydrolyse $\alpha-1,4-$ and not $\alpha-1,6$-linkages in pullulan. The final product is either panose (of pullulan hydrolase type I) or isopanose (of pullulan hydrolase type II). Pullulan hydrolase type III is a unique enzyme capable of hydrolysing both $\alpha-1,4$ and $\alpha-1,6$ glucosidic linkages in pullulan, and its final reaction products are a mixture of maltose, panose, and maltotriose [76].

Four GH13_20 have been structure-determined: a neopullulanase from Geobacillus stearothermophilus, $\alpha$-amylase 2 from Thermoactinomyces vulgaris R-47 (TVAII), cyclomaltodextrinase from Thermus sp. IM6501 and debranching enzyme from Nostoc punctiforme (Table 1). 


\section{Oligo- and glucan 1,6- $\alpha$-glucosidases}

GH13_31 encompasses isomaltulose synthases (EC 5.4.99.11), $\alpha$-glucosidases (EC 3.2.1.20), oligo- and glucan- $\alpha$-1,6-glucosidases (EC 3.2.1.10 and 3.2.1.70). Oligo- and glucan- $\alpha-1,6$-glucosidases hydrolyse $\alpha-1,6-$ linkages but differ in substrate size preference: i) glucan 1,6- $\alpha$-glucosidases (G16G) favour isomaltooligosaccharides (glucose units connected by $\alpha-1,6$-linkages) longer than the disaccharide isomaltose and are active on dextran (a linear $\alpha$-glucan composed of mainly $\alpha$-1,6-linked glucose units) and ii) oligo-1,6$\alpha$-glucosidases $(\mathrm{O} 16 \mathrm{G})$ prefer short isomaltooligosaccharides and have highest activity on isomaltose, but are inactive on dextran. Each type of enzyme is highly selective and shows little or no activity for other than $\alpha$ 1,6-linkages [77]. The GH13_31 members are unique in $\alpha$-glucan debranching, since they primarily act on the linear $\alpha$-glucan, dextran, but in addition can hydrolyse the $\alpha$-1,6-linkage in panose ( $\alpha$-D-Glc- $(1,6)-\alpha$-D-Glc$(1,4)-D-G l c)$ [78]. Pullulan, starch, or starch derived oligosaccharides are not hydrolysed by GH13_31 enzymes. Crystal structures are available of oligo- and glucan- $\alpha-1,6$-glucosidases from Bacillus cereus (O16G), Lactobacillus acidophilus (G16G), and Streptococcus mutans (G16G) (Table 1).

\section{Carbohydrate binding modules (CBMs) in relation to $\alpha$-glucan debranching enzymes}

A CBM is defined as a contiguous amino acid sequence within a carbohydrate-active enzyme with a discrete fold having carbohydrate-binding activity (www.cazy.org/Carbohydrate-Binding-Modules). The consensus function of such auxiliary domains is to bind polysaccharides and bring the catalytic domain in intimate contact with substrate, thus advancing carbohydrate hydrolysis. CBMs are grouped into 71 families according to CAZy [4] and possess a range of polysaccharide binding specificities. Several N-domains in $\alpha$-glucan debranching enzymes have been identified as CBMs. Carbohydrate binding of most of the $\mathrm{N}$-terminal domains has not been verified experimentally, but they share fold with functionally characterized CBMs [79]. The recognition of polysaccharides by CBMs plays a role in relation to metabolism, pathogen defence, polysaccharide biosynthesis, virulence, plant development etc. [80, 81]. In PULIs, CBMs are shown to be important for substrate specificity and catalytic efficiency [82].

Various CBMs occur in $\alpha$-glucan debranching enzymes, especially PULIs and PULIIs contain several different CBMs. The most prevalent CBMs among PULIs and PULIIs of GH13_12-14 are CBM41 and CBM48. Recently, one of the N-domains associated with GH13_14 enzymes (previously known as X45) was classified to the new family, CBM68 (Fig. 2) [83]. GH13_12-14 members also have N-domains with unknown function in addition to known CBMs. An N-terminal domain of barley limit dextrinase (PULI) from GH13_13 resembles a CBM21 starch-binding domain based on structural homology (Fig. 2) [79]. The N-domain of a sorghum limit dextrinase has surprising impact on digestibility of sorghum starch [84]. GH13_11 enzymes have only one CBM, CBM48 also seen in the pullulanases (Fig. 2). According to CAZy, all GH13_39 have a CBM34 some have even two, other associated CBMs differ among GH13_39 members. CBM20 is thus found in characterised GH13_39 enzymes. The Geobacillus stearothermophilus GH13_39 even has a CBM48 [4], 
and GH13_39 members have an N-domain (X25/N1) that resembles the N-domain in the structure of Bacillus acidopullulyticus GH13_14 PULI for which there is a structure (Fig. 2). N-terminal truncation of Geobacillus thermoleovorans GH13_39 PULII_I revealed this N-domain to be important in starch binding. Based on conserved amino acid residues at starch binding sites (SBSs) 1 and 2 of this domain, a relationship was suggested to CBM20, CBM48 and CBM69 [52]. Finally, some GH13_20s have CBM34 and GH13_31 enzymes lack CBMs. Generally, GH57 PULII_Is do not have CBMs, although two GH57 PULII_Is have two CBM20s (ACR80150 and AEX85885) [4, 85], and one GH57 PULII_I is annotated to have two CBM48s (ABR30664) [4].

\section{CBM20}

The CBM20s are known as classical C-terminal starch binding domains in microbial glucoamylases and amylases, and is one of the most thoroughly studied CBM families (see [85, 86] for reviews). CBM20 is mainly associated with starch-active proteins from GH families 13, 14, 15, and 77, but a few more GH families (14, 31, 57, 97, and 119) also contain CBM20. Furthermore, CBM20 is found in glucan phosphatases like the mammalian laforin and starch-excess protein-4 (SEX4) required for normal $\alpha$-glucan breakdown, and the two starch phosphorylating enzymes glucan, water dikinase and phosphoglucan, water dikinase [4, 85, 87]. CBM20s have two sites capable of binding granular starch $[85,88,89]$. In a very recent study of GH13_39 PULII_I from Thermoanaerobacter pseudoethanolicus (ABY95795) the CBM20 lacked SBS2, showing that the presence of two starch binding sites is not a must for CBM20 function, since this specific domain still affect the Thermoanaerobacter pseudoethanolicus PULII_I activity on amylopectin and starch granules [90].

None of the CBM20s associated with $\alpha$-glucan debranching enzymes have been structure-determined, but CBM20 structures are solved of enzymes from 14 organisms representing 6 different enzyme specificities: $\beta$ amylase (GH14; EC 3.2.1.2), $\beta$-cyclodextrin glucanotransferase (GH13_2; EC 2.4.1.19), maltogenic $\alpha$ amylase (Novamyl; GH13_2; EC 3.2.1.133), glucoamylase (GH15; EC 3.2.1.3), laforin, and glycerophosphodiester phosphodiesterase [4]. These include the NMR structure of Aspergillus niger glucoamylase CBM20 in complex with $\beta$-CD (PDB entry 1AC0) having two structurally and functionally independent binding sites. It is proposed that the first is for initial starch recognition, whereas the second site has higher carbohydrate affinity and locks CBM20 into place. A model structure showing two $\alpha$-glucan chains bound to CBM20 in perpendicular orientation, suggests that the CBM20 may force starch strands apart thus increasing the surface accessibility or localise the enzyme to non-crystalline areas of the starch granule [89]. Recently, CBM20 of human "starch-binding domain-containing protein 1" was found to be important for the protein stability and ability to interact with glycogen-associated proteins like glycogen synthase, glycogen debranching enzyme and laforin [90]. The "starch-binding domain-containing protein 1" is able to bind glycogen, and its CBM20 has been demonstrated to bind amylose [90].

\section{CBM34}

CBM34 has only been found associated with GH13 and GH77 proteins. Six CBM34 structures are solved: two in $\alpha$-amylases from Thermoactinomyces vulgaris R-47 (TVAI, GH13_21; TVAII, GH13_20, Table 1), one in 
amylase from Pyrococcus furiosus (no GH13 subfamily; PDB entry 4AEF) [91], and three in GH13_20 enzymes from Bacillus, Geobacillus and Thermus (Table 1). The CBM34 and CBM21 $\beta$-sheets share topology [92]. Raw starch-binding has been demonstrated in the case of the N-terminal domain of Thermoactinomyces vulgaris $\alpha$-amylase TVAI. The crucial Trp65 [93] of TVAI has no obvious counterpart in TVAII despite pronounced sequence similarity with the TVAI N-domain [93]. However, the N-domain of TVAII has been shown to play an essential role in activity as well as dimer formation [93].

\section{CBM41}

CBM41 is only found with GH13 pullulanases. The tandem CBM41s of PULIs from streptococci are welldescribed and attach the bacterium to glycogen reserves in alveolar cells enabling polysaccharide degradation by the pathogen; hence these CBM41s are referred to as virulence factors [94]. Remarkably, one of the two CBM41s in the N-terminal region of Streptococcus pneumoniae pullulanase forms part of the active site, and has an important role in activity [82]. Both crystallography, small-angle X-ray scattering (SAXS) and truncation data support this CBM41-active site coupling. The second CBM41 and most distal to the catalytic domain (Fig. 2) is proposed to adhere to glycogen particles [82, 95]. Kinetic analysis of Streptococcus pneumoniae pullulanase lacking both the N-terminal domain and both CBM41s, showed this truncated pullulanase to be roughly half as effective as wild-type in releasing maltooligosaccharides from glycogen, which is its in vivo function [82]. Furthermore, Streptococcus agalactiae pullulanase without the two CBM41s was less adhesive to human cervical epithelial cells than the full-length enzyme, supporting that the carbohydrate binding motifs of the CBM41s mediate adhesion [96]. CBM41 in GH13_14 PULI from Thermotoga maritima (AAD36907) is also well-characterised member. It served as a model for CBM41 $\alpha$ glucan binding as it was the first structure-determined CBM41 (PDB entry 2J72) [97]. It was shown to bind tightly to $\alpha$-1,4-glucans, $\alpha$-1,4-glucooligosaccharides, mixed $\alpha-1,4-1,6$-glucooligosaccharides, and pullulan $[82,97,98]$. Two of the PULIs have been structure-determined with maltooligosaccharides bound to their CBM41(s) (PDB entries 2YA1, 2FHC, and 2FHF; Table 1).

\section{CBM48}

CBM48s and the starch-binding CBM20 (see above) are closely related, but CBM48s has only one SBS (corresponding to CBM20 SBS1), whereas CBM20 generally has two SBSs [85]. CBM48 is mostly seen in GH13 subfamilies acting on branched substrates: glycogen and starch branching enzymes (GH13_8-9), GDEs and ISAs (GH13_11), PULIs and PULIIs (GH13_12-14), and cyclomaltodextrinases (GH13_20) [99]. Furthermore, CBM48s are also present in GH10, 26, 43, 57 and 77, in the $\beta$-subunit (glycogen-binding) of AMP-activated protein kinases, and in the glucan phosphatase SEX4 [4]. The CBM48s from AMP-activated protein kinases are among the best studied [100-102]. Crystal structures of AMP-activated kinase (PDB entry 1Z0M) and starch phosphatase DSP4 (PDB entry 4PYH) showed glucan binding to CBM48 [100, 103]. A recently characterised CBM48 forms a part of Arabidopsis Protein Targeting to Starch (PTST) required for amylose biosynthesis. The CBM48 mediates interaction of PTST with starch granules, and also secures correct localisation of granule-bound starch synthase (GBSS) in Arabidopsis [104]. 
In most CBM48s from GH13_11-14, the residues predicted to constitute the canonical SBS1 are not unambiguously conserved. Indeed, carbohydrate binding to CBM48 from ISA, GDEs, and pullulanases has not been demonstrated experimentally, but CBM48s from these enzymes possess a conserved tryptophan corresponding to Trp563 of the CBM20 SBS2 site in Aspergillus niger glucoamylase, suggesting that these sequences may be intermediates between CBM20 and CBM48 rather than being CBM48 [85]. By contrast CBM48 of branching enzymes binds glucans in crystal structures, thus maltopentaose is accommodated by CBM48 of rice branching enzyme (PDB entry 3VU2). The occupied binding sites were shown to be conserved in other starch branching enzymes [105]. Likewise, the crystal structure of the Escherichia coli branching enzyme solved in complex with maltooligosaccharides (PDB entries 4LQ1 and 4LPC) had maltose bound to its conserved CBM48 SBS [106].

\section{CBM68}

Recently, GH13_14 Anoxybacillus PULI was realised to contain a new N-terminal CBM [83] classified as CBM68 in CAZy [4]. Its binding function is deduced from crystal structures; CBM deletion caused reduced thermostability and specific activity, and increased $K_{\mathrm{m}}$ [83]. Two Anoxybacillus structures (PDB entries 3WDI and 3 WDJ) had parallel bound maltooligosaccharides accommodated close to each other between the Nterminal and the catalytic domains. These structures elicited assignment of the N-terminal domain as CBM68 with specificity for maltotriose and maltotetraose [83], and in Bacillus acidopullulyticus GH13_14 pullulanase the N-terminal domain previously known as X45 was classified as CBM68 [4]. CBM68 has so far only been seen in pullulanases, at present in 206 sequences [4].

\section{$\alpha$-glucan debranching enzymes similarities and differences at sequence and structure level}

\section{Phylogenetic analysis}

Phylogenetic analysis of GH13 $\alpha$-glucan debranching enzymes shows that PULIs in subfamilies GH13_1214 are closely related with GH13_13 and 14 enzymes forming their own cluster (Fig. 3). In more detail, GH13_12 PULIs cluster together with GH13_12+41 PULII_IIs, and it seems plausible that GH13_12+41 and GH13_14+41 PULII_IIs evolved from a PULI by gene fusion, although there is currently no additional support for this hypothesis. The GH13_11 cluster is well-defined, adjacent to the PULI clusters, and slightly more distantly related to GH13_31. The GH13_39 PULII_Is cluster together with the GH13_20 sub-cluster. The analysis also shows that GH13_31 and GH13_20 enzymes are distantly related. Clearly, GH13_39 PULII_Is, however, are more closely related to GH13_20 enzymes, which, like GH13_39 enzymes, have one active site for hydrolysing both $\alpha-1,4-$ and $\alpha-1,6$ - linkages. GH13_20 enzymes, however, in general prefers $\alpha$-1,4- over $\alpha-1,6$-linkages, while enzymes of GH13_39 show the opposite trend. Based on this phylogenetic analysis we suggest that GH13_39 PULII_Is being intermediates of GH13_20 having dual bond-type specificity, and GH13_31 of strict $\alpha-1,6$-specificity. GH13_39 PULII_Is evolutionary are also more evolutionary related to GH13_20 enzymes than to GH13_12-14 pullulanases in accordance with their associated CBMs, thus CBM34 are found with both GH13_20 and GH13_39 and is not found with GH13_12-14 enzymes. Finally, the 
phylogenetic analysis showed GH57 PULII_Is as distantly related to GH13_13 and GH13_14 PULIs (Fig. 3). The different folds and the fact that there are no conserved sequence motifs shared between the GH57 and GH13 enzymes make joint phylogenetic analysis of these GH families futile.

\section{Structure based comparison of $\alpha$-glucan debranching enzymes}

Comparison of overall structures of six $\alpha$-glucan debranching GH13 subfamilies shows obvious differences with regard to number and types of non-catalytic domains (Fig. 2), but variation is also seen between the subfamilies in the catalytic domains around the active site (Fig. 5). GH13_11-14 and GH13_20 enzymes have an open cleft-shaped active site, as opposed to a closed pocket-shaped active site is seen for the exo-acting GH13_31 (Fig. 5). The architecture of the active sites defines size and structure of the preferred substrates; even small differences in the curvature of the cleft-shaped active sites can define optimal lengths of substrate main chains and branches. Such differences within and between subfamilies are discussed intensely in the literature on crystal structures of GH13_11-14 enzymes [16, 19, 30, 36, 107] for example in search for an explanation of GH13_11 enzymes having no or very low activity on pullulan. Superimposition of a GH13_13 structure in complex with a pullulan fragment with the GH13_11 structures shows it has an active site loop at the minus subsite region (glycon binding) that sterically hinders binding of the staircase-shaped pullulan (Fig. 5a). Closer inspection of all $\alpha$-glucan debranching enzyme structures with substrates or products bound at the active site makes it clear that orientation and position of the ligands vary significantly among the subfamilies. Only the glucose unit bound at subsite -1 superimposes well across subfamilies (Fig. 6a). However, not all subfamilies are represented by structures where both the plus (aglycone binding) and minus subsites, i.e. both sides of the cleavage site, are occupied by ligand. PULI subfamilies 12-14 have superimposing glucose units at subsites +1 and +2 in addition to subsite -1 , illustrating their close relationship. The lonely glucose unit bound in subsite +2 of the Chlamydomonas reinhardtii ISA (PDB entry 4OKD) and Sulfolobus solfataricus GDE (PDB entry 2VR5) of GH13_11 also superimposes with glucose units in GH13_12-14 structures. The plus subsites of the barley PULI have been proposed to be high-affinity subsites, while branch binding minus subsites are proposed to be of low-affinity [36].

\section{Conserved regions}

The $\alpha$-glucan debranching enzymes are a relatively heterogeneous group when it comes to substrate specificity and preference. However, in spite of their mutual differences certain amino acid residues around the active site are conserved at positions defining the classical conserved sequences in GH13 (regions I-IV [6], Fig. 4). These motifs are to some extent useful to distinguishing the GH13 subfamilies. A great number of mutational studies are published on the importance of residues conserved among GH13 enzymes and within subfamilies. Here the focus is on residues important for modulating $\alpha-1,6$-activity or for discriminating individual $\alpha$-glucan debranching GH13 subfamilies where structure-determined enzymes serve as examples.

Region I is not interacting directly with ligands in the active site, but mutational analysis of the histidine has shown that it is essential for catalytic activity for a GH13_13 PULI from Klebsiella [108]. 
Region II harbours the catalytic nucleophile and even though the primary structure appears to differ considerably at certain positions, when comparing all structures of GH13 debranching subfamilies, a very strict conservation of the spatial position of not only the backbone, but also the rotamers of the varying residues make these superimpose perfectly (Fig. 6b). The valine (Val195) next to the catalytic nucleophile (Fig. 6b and c) was shown by mutational analysis to be important for the $\alpha-1,6$-activity of the GH13_31 enzyme from Streptococcus mutans (PDB entry 2ZIC), since the corresponding alanine mutant changed specificity to $\alpha-1,4-$ activity [109]. Additionally, a lysine (Lys275) in region III and a glutamic acid (Glu371) outside the active site were shown to be central structural elements in the recognition of $\alpha-1,6$-glucosidic linkages [109]. The valine of region II was also important for the preference for $\alpha-1,4$ - and $\alpha-1,6$-glucosidic linkages of the GH13_20 Thermoactinomyces vulgaris TVAII (PDB entry 1BVZ). Mutation to alanine altered the linkage preference from $\alpha-1,6$ - to $\alpha-1,4-$ linkages [110]. Comparison of representative structures from $\alpha$-glucan debranching GH13 subfamilies with that of a Bacillus subtilis $\alpha$-amylase (GH13_28) with a maltopentaose molecule spanning the catalytic site (PDB entry 1BAG) clearly shows that the position equivalent to Val195 of Streptococcus mutans will constrain linkage type variability with respect to the subsite -1 and +1 linkage: A small amino acid like alanine, found in $\alpha$-amylases, gives the spaciousness needed for the short and rigid $\alpha$ 1,4-linkage, whereas increased size of the amino acid in position 195 makes it harder to accommodate an $\alpha$ 1,4-linkage (Fig. 6c). The $\alpha-1,6$-specific PULIs have large amino acids like methionine or leucine at this position, while GH13_20, GH13_31, and GH13_39 have the smaller valine (Fig. 4).

Region III forms subsite +2 and harbours the general acid/base catalyst. This region has been suggested to be important for substrate binding in PULIs, especially the tryptophan that stacks with the glucose unit in subsite +2 was proposed to be critical (Fig. 6d) [36]. This tryptophan is conserved in the different subfamilies (Fig. 4), but due to variation in the loop positions of GH13_20 and GH13_31 structures it clashes with ligands accommodated in GH13_13 structures where an $\alpha$-1,6-linkage is spanning the catalytic site. Kuriki showed that mutation of an isoleucine adjacent to the conserved tryptophan in GH13_20 from Bacillus stearothermophilus (PDB entry 1J0H) modulated $\alpha-1,6$-activity (Fig. $6 \mathrm{~d}$ ): the isoleucine to tryptophan mutant had reduced $\alpha$-1,6-activity, while replacement with valine increased the $\alpha$-1,6-acitivity [111]. The tryptophan of the GH13_31 enzyme from Streptococcus mutans (Trp238) was shown by mutational analysis to be very important for hydrolytic activity especially on long chain substrates [112]. Moreover, from a structure comparison of the four structure-determined GH13_11 members it is seen that GH13_11 structures vary in region III. Thus loop following the general acid/base of the GDE from Sulfolobus solfataricus has a completely different direction (Fig. 6d).

The backbone of region IV superimposes perfectly despite differences in amino acid residue types at some positions (Fig. 4 and Fig. 6e). Region IV harbours the aspartate that functions as transition state stabiliser, which shows rotamer variation among different GH13 structures (Fig. 6e) depending noticeably on the absence or presence of ligand [36]. By contrast, the invariant histidine in region IV is crucial for activity [108] forms forms part of subsite -1 and adopts the same rotamer in all the structures (Fig. 6e). Furthermore at region IV, the tyrosine in GH13_12-14 PULIs (Fig. 4) is on average $4.5 \AA$ from the glucose unit at subsite +1 . 
Remarkably, this tyrosine ring superimposes with the aromatic ring of the equivalent histidine in GH13_11 (Fig. 6e).

In addition to the four classical conserved GH13 regions, region V is proposed to define subfamilies GH13_20 and GH13_31, GH13_20 having an MPKln and GH13_31 a corresponding QpDln motif in this region (Fig. 4). Enzymes with MPDLN are suggested to create an intermediary group having diverse enzyme specificity of $\alpha$-amylase, cyclomaltodextrinase and neopullulanase [77, 113].

Regions VI and VII are suggested as signature regions of ISAs, PULIs and PULIIs [114-119]. Region VI was noted to distinguish ISAs and pullulanases: ISAs having VIYEVHVRG and PULIs IYELHIRDFS [114]. It is a part of the core of the $(\beta / \alpha)_{8}$-barrel and not in the active site, but interacts directly with region VII that generally forms a part of subsite -2. Different signature motifs of region VII have been suggested: YNWGYDP (PULI) and NYWGY (ISA) [114]; -NWGY- (PULIs) and -NH(K/R)Y- (PULIIs) [118, 119]. Based on a multiple sequence alignment only including the catalytic domains of PULII_Is and PULII_IIs these motifs clearly should be further specified, as PULIs and PULII_IIs both have $-\mathrm{NWGY}$ - while $-\mathrm{NH}(\mathrm{K} / \mathrm{R}) \mathrm{Y}-$ is signature motif for GH13_39 PULII_Is [43]. There are exceptions, however, thus PULII_IIs can thus possess the signature motif of a PULI. This correlates with the fact that the pullulanase domain of PULII_IIs is phylogenetically similar to PULI domains (Fig. 3). Comparison of region VII from PULI, ISA, and GDE structures shows the tryptophan and the second tyrosine to superimpose very well for these members of different subfamilies, and that the aromatic ring of the first tyrosine residues in the sequence motif VII motif superimpose despite a shift of one residue (Fig. 6f). The major difference between PULIs and GH13_11 enzymes in this region is the interplay of the asparagine and the aspartic acid of the PULIs, which interact with each other as well as with the glucose unit in subsite -2 and even a terminal glucose unit in the pullulan fragment (PDB entry 4J3X). In the GH13_11 enzymes, the asparagine makes contact with the glucose unit in subsite -2 .

\section{Biological function and industrial application of $\alpha$-glucan debranching enzymes}

Most $\alpha$-glucan debranching enzymes serve in mobilization of energy in eukaryotes, archaea and bacteria by degrading the storage carbohydrates glycogen and amylopectin. $\alpha$-glucan debranching enzymes, however, have also been shown to participate in biosynthesis of the $\alpha$-glucans. Thus in plants debranching is required to modify the structure of the growing amylopectin molecule to a more ordered structure, which as a consequence promotes the formation of crystalline amylopectin regions essential to the integrity of the starch granule [120]. All plants characterised to date contain two conserved types of starch debranching enzymes; PULI (in plants called limit dextrinase) and ISA of which at least three genes (ISA1-3) are found [121]. ISA and PULI appear to be conserved separately during evolution of prokaryotes and higher plants, and these enzymes are more closely related to a bacterial counterpart than to the other type of plant debranching enzyme [121]. The physiological function of ISA in starch biosynthesis is well-established based on mutants deficient in one or more ISA isoforms in barley [122], Arabidopsis [123-125], maize [126], and rice [127-130]. Generally, ISA is assumed to catalyse editing of excessively branched chains or removal of improper branches 
formed in biosynthesis of amylopectin by branching enzymes to achieve the cluster structure of amylopectin [131-133]. These studies show that lack of ISA results in production of the disordered water-soluble polysaccharide, phytoglycogen, that resembles glycogen and lacks the structural features of amylopectin that allow formation of crystalline regions in starch granules.

Compared with ISA, the role of the limit dextrinase (PULI) in starch biosynthesis is less well-established. However, besides during germination, substantial PULI activity has been detected in developing rice and maize endosperms $[114,134]$, and the presence of mRNA for barley limit dextrinase was found in this stage of the plant lifecycle [135]. PULI is thus proposed to participate in starch synthesis in rice, maize and Arabidopsis $[121,124,129]$. Mutational studies of the starch debranching enzymes in higher plants however display distinct and slightly different expression profiles of mutant phenotypes leading to contradictory interpretations. One explanation for these small, albeit significant differences could be some level of functional overlap of the various starch debranching enzymes. If the balance between the starch debranching enzymes or their degree of functional redundancy varies from species to species these small differences might explain the apparent contradictory observations [124].

Bacterial pullulanases are often extracellular being either secreted or attached to the cell surface [136]. Besides the important for degradation of $\alpha$-glucans into maltooligosaccharides, to be transported into cells to enter the intracellular energy metabolism, the extracellular pullulanases can have another role: PULIs from Streptococcus were shown to be so-called virulence factors that facilitate binding of streptococci to host mucus e.g. in lungs. As already mentioned it is the CBM41s, which contribute to binding of cell surface attached pullulanases to the epithelial mucus layer [94, 96].

\section{Industrial application}

Industrial use of $\alpha$-glucan debranching enzymes comprises two areas: degradation of starch into glucose, maltose, and maltodextrins and production of carbohydrates with new functions. Starch is a major raw material for the brewing industry and in the manufacture of various products such as bio-ethanol, coating agents in the paper industry, anti-staling agents, and sugar syrups. Debranching enzymes play a key role together with the amylases in these industrial processes. Starch saccharification at very high rate and at low temperature is attractive for commercial food, feed and fuel production. To this end, well-known high rate ethanol producers like Saccharomyces cerevisiae with high ethanol tolerance have been complemented with glucoamylases and $\alpha$-glucan debranching enzymes to achieve the saccharification and debranching needed for complete hydrolysis of starch to ethanol by S. cerevisiae [137]. Furthermore, $\alpha$-glucan degrading enzymes are prominent additives to detergents, where they function to remove starch stains from cloth. Due to the industrial importance of $\alpha$-glucan debranching enzymes several review articles focus on this topic [37, 138-141]. Especially enzymes from thermophilic and mesophilic organisms received much attention in relation to industrial applications, due to their high stability under extreme temperature and $\mathrm{pH}$ conditions ensuring robust industrial processes [142].

GH13_20 enzymes play a role in relation to production of carbohydrates with new functions, e.g. of linear or cyclic oligosaccharides proposed to have prebiotic properties [143, 144]. An emerging biotechnology could 
involve engineering of the repertoire of $\alpha$-glucan debranching enzymes in planta for modification of starch structure and large-scale production for more or less easily digestible food and feed. This approach for utilisation of the industrial potential of $\alpha$-glucan debranching enzymes is still in its infancy.

\section{Conclusions}

The present review emphasises that $\alpha$-glucan debranching enzymes are a diverse group of enzymes, with remarkable differences and similarities currently found in GH13 subfamilies and GH57. The first PULI crystal structure solved a decade ago is today complemented by a very valuable knowledge-base of both free and carbohydrate complexed structures, including the first branched substrate complex structure, that is key to understanding the relationship between structure and function for $\alpha$-glucan debranching enzymes. But important enzyme types remain to be structure-determined. The phylogenetic analysis presented here indicate that GH13_39 is a missing link between the strict $\alpha$-1,6-acting PULIs and pullulan hydrolases with dual $\alpha$ 1,4- and $\alpha-1,6$-linkage specificity, which draws special attention to the fact that novel structures of GH13_39 and GH57 PULII_Is are lacking.

The many new structures have made it possible to decipher $\alpha-1,6$-bond type specificity versus $\alpha$-1,4-bond type specificity and identify sub-structures and sequence motifs that functionally differentiates the various types of $\alpha$-glucan debranching enzymes. These sub-structures and sequence motifs can serve as inspiration for enzyme design but novel structures of $\alpha$-glucan debranching enzymes and/or complementary data are needed to add enough detail to the activity and specificity knowledge to allow enzymes of potential industrial relevance to be rationally engineered.

\section{Acknowledgements}

Bernard Henrissat is gratefully acknowledged for sharing information on new GH13 subfamilies of which GH13_41 is addressed in the present review. This work was supported by The Danish Council for Independent Research|Technology and Production Sciences (to MSM), and a Sapere Aude-Research Talent grant from the Danish Council for Independent Research|Technology and Production Sciences (to MSM). 


\section{REFERENCES}

1 Chi Z, Wang F, Chi Z, Yue L, Liu G and Zhang T (2009) Bioproducts from Aureobasidium pullulans, a biotechnologically important yeast. Appl Microbiol Biotechnol 82(5):793-804

2 Vamadevan V and Bertoft E (2015) Structure-function relationships of starch components. Starch-Stärke 67(1-2):55-68

3 Roach PJ, Depaoli-Roach AA, Hurley TD and Tagliabracci VS (2012) Glycogen and its metabolism: some new developments and old themes. Biochem J 441:763-787

4 Lombard V, Ramulu HG, Drula E, Coutinho PM and Henrissat B (2014) The carbohydrate-active enzymes database (CAZy) in 2013. Nucleic Acids Res 42(D1):D490-D495

5 Stam MR, Danchin EGJ, Rancurel C, Coutinho PM and Henrissat B (2006) Dividing the large glycoside hydrolase family 13 into subfamilies: towards improved functional annotations of $\alpha$-amylase-related proteins. Protein Eng Des Sel 19(12):555-562

6 MacGregor EA, Janeček S and Svensson B (2001) Relationship of sequence and structure to specificity in the $\alpha$-amylase family of enzymes. Biochim Biophys Acta, Protein Struct Mol Enzymol 1546(1):1-20

7 Kuriki T and Imanaka T (1999) The concept of the $\alpha$-amylase family: structural similarity and common catalytic mechanism. J Biosci Bioeng 87(5):557-565

8 Janecek S, Svensson B and MacGregor EA (2014) $\alpha$-amylase: an enzyme specificity found in various families of glycoside hydrolases. Cell Mol Life Sci 71(7):1149-1170

9 Janecek S and Blesak K (2011) Sequence-structural features and evolutionary relationships of family GH57 $\alpha$-amylases and their putative $\alpha$-amylase-like homologues. Protein J 30(6):429-435

10 Park K, Jung J, Park S, Lee M, Holden JF, Park C and Woo E (2014) Structural features underlying the selective cleavage of a novel exo-type maltose-forming amylase from Pyrococcus sp. ST04. Acta Crystallogr Sect D-Biol Crystallogr 70(6):1659-1668

11 Zona R, Chang-Pi-Hin F, O'Donohue M and Janecek S (2004) Bioinformatics of the glycoside hydrolase family 57 and identification of catalytic residues in amylopullulanase from Thermococcus hydrothermalis. Eur J Biochem 271(14):2863-2872

12 Kang S, Vieille C and Zeikus J (2005) Identification of Pyrococcus furiosus amylopullulanase catalytic residues. Appl Microbiol Biotechnol 66(4):408-413

13 Janeček S (2005) Amylolytic families of glycoside hydrolases: focus on the family GH-57. Biologia $60177-184$

14 Blesak K and Janecek S (2012) Sequence fingerprints of enzyme specificities from the glycoside hydrolase family GH57. Extremophiles 16(3):497-506

15 Marchler-Bauer A, Derbyshire MK, Gonzales NR, Lu S, Chitsaz F, Geer LY, Geer RC, He J, Gwadz M, Hurwitz DI, Lanczycki CJ, Lu F, Marchler GH, Song JS, Thanki N, Wang Z, Yamashita RA, Zhang D, Zheng C and Bryant SH (2015) CDD: NCBI's conserved domain database. Nucleic Acids Res 43(D1):D222-D226 
16 Sim L, Beeren SR, Findinier J, Dauvillee D, Ball SG, Henriksen A and Palcic MM (2014) Crystal structure of the Chlamydomonas starch debranching enzyme isoamylase ISA1 reveals insights into the mechanism of branch trimming and complex assembly. J Biol Chem 289(33):22991-23003

17 Hussain H, Mant A, Seale R, Zeeman S, Hinchliffe E, Edwards A, Hylton C, Bornemann S, Smith A, Martin C and Bustos R (2003) Three isoforms of isoamylase contribute different catalytic properties for the debranching of potato glucans. Plant Cell 15(1):133-149

18 Tetlow IJ (2011) Starch biosynthesis in developing seeds. Seed Sci Res 21(1):5-32

19 Song H, Jung T, Park J, Park B, Myung PK, Boos W, Woo E and Park K (2010) Structural rationale for the short branched substrate specificity of the glycogen debranching enzyme GlgX. Proteins Struct Funct Bioinf 78(8): 1847-1855

20 Abe J, Ushijima C and Hizukuri S (1999) Expression of the isoamylase gene of Flavobacterium odoratum KU in Escherichia coli and identification of essential residues of the enzyme by site-directed mutagenesis. Appl Environ Microbiol 65(9):4163-4170

21 Maruta K, Mitsuzumi H, Nakada T, Kubota M, Chaen H, Fukuda S, Sugimoto T and Kurimoto M (1996) Cloning and sequencing of a cluster of genes encoding novel enzymes of trehalose biosynthesis from thermophilic archaebacterium Sulfolobus acidocaldarius. Biochim Biophys Acta 1291(3):177-181

22 Van TTK, Ryu S, Lee K, Kim E and Lee S (2007) Cloning and characterization of glycogen-debranching enzyme from hyperthermophilic archaeon Sulfolobus shibatae. J Microbiol Biotechn 17(5):792-799

23 Seibold GM and Eikmanns BJ (2007) The glgX gene product of Corynebacterium glutamicum is required for glycogen degradation and for fast adaptation to hyperosmotic stress. Microbiol SGM 1532212-2220

24 Krohn B, Barry G and Kishore G (1997) An isoamylase with neutral pH optimum from a Flavobacterium species: Cloning, characterization and expression of the iam gene. Mol Gen Genet 254(5):469-478

25 Fujita N, Kubo A, Francisco P, Nakakita M, Harada K, Minaka N and Nakamura Y (1999) Purification, characterization, and cDNA structure of isoamylase from developing endosperm of rice. Planta 208(2):283-293

26 Hong S and Preiss J (2000) Localization of C-terminal domains required for the maximal activity or for determination of substrate preference of maize branching enzymes. Arch Biochem Biophys 378(2):349355

27 Ito H, Hamada S, Isono N, Yoshizaki T, Ueno H, Yoshimoto Y, Takeda Y and Matsui H (2004) Functional characteristics of C-terminal regions of starch-branching enzymes from developing seeds of kidney bean (Phaseolus vulgaris L.). Plant Sci 166(5):1149-1158

28 Palomo M, Kralj S, van der Maarel MJEC and Dijkhuizen L (2009) The unique branching patterns of Deinococcus glycogen branching enzymes are determined by their N-terminal domains. Apple Environ Microbiol 75(5):1355-1362

29 Katsuya Y, Mezaki Y, Kubota M and Matsuura Y (1998) Three-dimensional structure of Pseudomonas isoamylase at 2.2 angstrom resolution. J Mol Biol 281(5):885-897 
30 Woo E, Lee S, Cha H, Park J, Yoon S, Song H and Park K (2008) Structural insight into the bifunctional mechanism of the glycogen-debranching enzyme TreX from the archaeon Sulfolobus solfataricus. J Biol Chem 283(42):28641-28648

31 Cuyvers S, Dornez E, Delcour JA and Courtin CM (2012) Occurrence and functional significance of secondary carbohydrate binding sites in glycoside hydrolases. Crit Rev Biotechnol 32(2):93-107

32 Min-ho L, Hyung-Nam S, Ji-Eun C, Lan TP, Sunghoon P, Jong-Tae P and Eui-Jeon W (2014) Association of bi-functional activity in the N-terminal domain of glycogen debranching enzyme. Biochem Biophys Res Commun 445(1):107-112

33 Liu W, Madsen N, Braun C and Withers S (1991) Reassessment of the catalytic mechanism of glycogen debranching enzyme. Biochemistry 30(5):1419-1424

34 Nakayama A, Yamamoto K and Tabata S (2001) Identification of the catalytic residues of bifunctional glycogen debranching enzyme. J Biol Chem 276(31):28824-28828

35 Ara K, Igarashi K, Saeki K and Ito S (1995) An alkaline amylopullulanase from alkalophilic Bacillus sp KSM-1378; kinetic evidence for 2 independent active-sites for the $\alpha-1,4$ and $\alpha-1,6$ hydrolytic reactions. Biosci Biotechnol Biochem 59(4):662-666

36 Møller MS, Windahl MS, Sim L, Bojstrup M, Abou Hachem M, Hindsgaul O, Palcic M, Svensson B and Henriksen A (2015) Oligosaccharide and substrate binding in the starch debranching enzyme barley limit dextrinase. J Mol Biol 427(6):1263-1277

37 Nisha M and Satyanarayana T (2013) Recombinant bacterial amylopullulanases. Developments and perspectives. Bioengineered 4(6):388-400

38 Kim J, Sunako M, Ono H, Murooka Y, Fukusaki E and Yamashita M (2008) Characterization of gene encoding amylopullulanase from plant-originated lactic acid bacterium, Lactobacillus plantarum L137. J Biosci Bioeng 106(5):449-459

39 Kim J, Sunako M, Ono H, Murooka Y, Fukusaki E and Yamashita M (2009) Characterization of the Cterminal truncated form of amylopullulanase from Lactobacillus plantarum L137. J Biosci Bioeng 107(2):124-129

40 Ferrando ML, Fuentes S, de Greeff A, Smith H and Wells JM (2010) ApuA, a multifunctional $\alpha$-glucandegrading enzyme of Streptococcus suis, mediates adhesion to porcine epithelium and mucus. Microbiology 156:2818-2828

41 Hatada Y, Igarashi K, Ozaki K, Ara K, Hitomi J, Kobayashi T, Kawai S, Watabe T and Ito S (1996) Amino acid sequence and molecular structure of an alkaline amylopullulanase from Bacillus that hydrolyzes $\alpha$ 1,4 and $\alpha-1,6$ linkages in polysaccharides at different active sites. J Biol Chem 271(39):24075-24083

42 O'Connell Motherway M, Fitzgerald GF, Neirynck S, Ryan S, Steidler L and van Sinderen D (2008) Characterization of ApuB, an extracellular type II amylopullulanase from Bifidobacterium breve UCC2003. Appl Environ Microbiol 74(20):6271-6279

43 Lee YS, Seo SH, Yoon SH, Kim SY, Hahn BS, Sim JS, Koo BS and Lee CM (2016) Identification of a novel alkaline amylopullulanase from a gut metagenome of Hermetia illucens. Int J Biol Macromolec $82: 514-522$ 
44 Han T, Zeng F, Li Z, Liu L, Wei M, Guan Q, Liang X, Peng Z, Liu M, Qin J, Zhang S and Jia B (2013) Biochemical characterization of a recombinant pullulanase from Thermococcus kodakarensis KOD1. Lett Appl Microbiol 57(4):336-343

45 Guan Q, Guo X, Han T, Wei M, Jin M, Zeng F, Liu L, Li Z, Wang Y, Cheong G, Zhang S and Jia B (2013) Cloning, purification and biochemical characterisation of an organic solvent-, detergent-, and thermostable amylopullulanase from Thermococcus kodakarensis KOD1. Process Biochem 48(5-6):878-884

46 Koivula T, Hemila H, Pakkanen R, Sibakov M and Palva I (1993) Cloning and sequencing of a gene encoding acidophilic amylase from Bacillus acidocaldarius. J Gen Microbiol 139:2399-2407

47 Bai Y, Huang H, Meng K, Shi P, Yang P, Luo H, Luo C, Feng Y, Zhang W and Yao B (2012) Identification of an acidic $\alpha$-amylase from Alicyclobacillus sp A4 and assessment of its application in the starch industry. Food Chem 131(4):1473-1478

48 Lee S, Morikawa M, Takagi M and Imanaka T (1994) Cloning of the aapT gene and characterization of its product, $\alpha$-amylase-pullulanase (AapT), from thermophilic and alkaliphilic Bacillus sp. strain XAL601. Appl Environ Microbiol 60(10):3764-3773

49 Ferner-Ortner-Bleckmann J, Huber-Gries C, Pavkov T, Keller W, Mader C, Ilk N, Sleytr UB and Egelseer EM (2009) The high-molecular-mass amylase (HMMA) of Geobacillus stearothermophilus ATCC 12980 interacts with the cell wall components by virtue of three specific binding regions. Mol Microbiol 72(6):1448-1461

50 Chen J, Chen M, Chen L and Chu W (2001) Structure and expression of an amylopullulanase gene from Bacillus stearothermophilus TS-23. Biotechnol Appl Biochem 33:189-199

51 Nisha M and Satyanarayana T (2013) Characterization of recombinant amylopullulanase (gt-apu) and truncated amylopullulanase (gt-apuT) of the extreme thermophile Geobacillus thermoleovorans NP33 and their action in starch saccharification. Appl Microbiol Biotechnol 97(14):6279-6292

52 Nisha M and Satyanarayana T (2015) The role of N1 domain on the activity, stability, substrate specificity and raw starch binding of amylopullulanase of the extreme thermophile Geobacillus thermoleovorans. Appl Microbiol Biotechnol 99(13):5461-5474

53 Mathupala S, Saha B and Zeikus J (1990) Substrate competition and specificity at the active site of amylopullulanase from Clostridium thermohydrosulfuricum. Biochem Biophys Res Commun 166(1):126-132

54 Mathupala S, Lowe S, Podkovyrov S and Zeikus J (1993) Sequencing of the amylopullulanase (apu) gene of Thermoanaerobacter ethanolicus $39 \mathrm{E}$, and identification of the active site by site-directed mutagenesis. J Biol Chem 268(22):16332-16344

55 Ramesh M, Podkovyrov S, Lowe S and Zeikus J (1994) Cloning and sequencing of the Thermoanaerobacterium saccharolyticum B6A-RI apu gene and purification and characterization of the amylopullulanase from Escherichia coli. Appl Environ Microbiol 60(1):94-101

56 Melasniemi H (1988) Purification and some properties of the extracellular $\alpha$-amylase-pullulanase produced by Clostridium thermohydrosulfuricum. Biochem J 250(3):813-818 
57 Spreinat A and Antranikian G (1992) Analysis of the amylolytic enzyme-system of Clostridium thermosulfurogenes EM1: Purification and synergistic action of pullulanases and maltohexaose forming $\alpha$-amylase. Starch-Stärke 44(8):305-312

58 Matuschek M, Burchhardt G, Sahm K and Bahl H (1994) Pullulanase of Thermoanaerobacterium thermosulfurigenes EM1 (Clostridium thermosulfurogenes): Molecular analysis of the gene, composite structure of the enzyme, and a common model for its attachment to the cell surface. J Bacteriol 176(11):3295-3302

59 Kahar UM, Chan K, Salleh MM, Hii SM and Goh KM (2013) A high molecular-mass Anoxybacillus sp SK3-4 amylopullulanase: Characterization and its relationship in carbohydrate utilization. Int J Mol Sci 14(6):11302-11318

$60 \mathrm{Li} \mathrm{X}$ and Li D (2015) Preparation of linear maltodextrins using a hyperthermophilic amylopullulanase with cyclodextrin- and starch-hydrolysing activities. Carbohydr Polym 119:134-141

61 Siddiqui MA, Habib-ur-Rehman and Rashid N (2014) Gene cloning and characterization of a type II pullulanase hydrolase from a hyperthermophilic archaeon, Pyrobaculum calidifontis. Pak J Zool 46(4):1077-1084

62 Dong G, Vieille C and Zeikus J (1997) Cloning, sequencing, and expression of the gene encoding amylopullulanase from Pyrococcus furiosus and biochemical characterization of the recombinant enzyme. Appl Environ Microbiol 63(9):3577-3584

63 Choi K and Cha J (2015) Membrane-bound amylopullulanase is essential for starch metabolism of Sulfolobus acidocaldarius DSM639. Extremophiles 19(5):909-920

64 Li X, Li D and Park K (2013) An extremely thermostable amylopullulanase from Staphylothermus marinus displays both pullulan- and cyclodextrin-degrading activities. Appl Microbiol Biotechnol 97(12):53595369

65 Erra-Pujada M, Debeire P, Duchiron F and O'Donohue M (1999) The type II pullulanase of Thermococcus hydrothermalis: Molecular characterization of the gene and expression of the catalytic domain. J Bacteriol 181(10):3284-3287

66 Brown S and Kelly R (1993) Characterization of amylolytic enzymes, having both $\alpha-1,4$ and $\alpha-1,6$ hydrolytic activity, from the thermophilic archaea Pyrococcus furiosus and Thermococcus litoralis. Appl Environ Microbiol 59(8):2614-2621

67 Jiao Y, Wang S, Lv M, Xu J, Fang Y and Liu S (2011) A GH57 family amylopullulanase from deep-sea Thermococcus siculi: Expression of the gene and characterization of the recombinant enzyme. Curr Microbiol 62(1):222-228

68 Park KH, Kim TJ, Cheong TK, Kim JW, Oh BH and Svensson B (2000) Structure, specificity and function of cyclomaltodextrinase, a multispecific enzyme of the $\alpha$-amylase family. Biochim Biophys Acta-Protein Struct Molec Enzym 1478(2):165-185

69 Lee HS, Kim MS, Cho HS, Kim JI, Kim TJ, Choi JH, Park C, Lee HS, Oh BH and Park KH (2002) Cyclomaltodextrinase, neopullulanase, and maltogenic amylase are nearly indistinguishable from each other. J Biol Chem 277(24):21891-21897 
70 Kim T, Kim M, Kim B, Kim J, Cheong T, Kim J and Park K (1999) Modes of action of acarbose hydrolysis and transglycosylation catalyzed by a thermostable maltogenic amylase, the gene for which was cloned from a Thermus strain. Appl Environ Microbiol 65(4):1644-1651

71 Kim J, Cha S, Kim H, Kim T, Ha N, Oh S, Cho H, Cho M, Kim M, Lee H, Kim J, Choi K, Park K and Oh B (1999) Crystal structure of a maltogenic amylase provides insights into a catalytic versatility. J Biol Chem 274(37):26279-26286

72 Dumbrepatil AB, Choi J, Park JT, Kim M, Kim TJ, Woo E and Park KH (2010) Structural features of the Nostoc punctiforme debranching enzyme reveal the basis of its mechanism and substrate specificity. Proteins Struct Funct Bioinf 78(2):348-356

73 Ohtaki A, Mizuno M, Yoshida H, Tonozuka T, Sakano Y and Kamitori S (2006) Structure of a complex of Thermoactinomyces vulgaris R-47 $\alpha$-amylase 2 with maltohexaose demonstrates the important role of aromatic residues at the reducing end of the substrate binding cleft. Carbohydr Res 341(8):1041-1046

74 Cho H, Kim Y, Kim T, Lee H, Kim D, Kim J, Lee Y, Lee S and Park K (2000) Molecular characterization of a dimeric intracellular maltogenic amylase of Bacillus subtilis SUH4-2. Biochim Biophys Acta 1478(2):333-340

75 Mehta D and Satyanarayana T (2013) Dimerization mediates thermo-adaptation, substrate affinity and transglycosylation in a highly thermostable maltogenic amylase of Geobacillus thermoleovorans. Plos One 8(9):1-13

76 Ahmad N, Rashid N, Haider MS, Akram M and Akhtar M (2014) Novel maltotriose-hydrolyzing thermoacidophilic type III pullulan hydrolase from Thermococcus kodakarensis. Appl Environ Microbiol 80(3):1108-1115

77 Møller MS, Fredslund F, Majumder A, Nakai H, Poulsen JN, Lo Leggio L, Svensson B and Abou Hachem M (2012) Enzymology and structure of the GH13_31 glucan 1,6- $\alpha$-glucosidase that confers isomaltooligosaccharide utilization in the probiotic Lactobacillus acidophilus NCFM. J Bacteriol 194(16):4249-4259

78 Makelainen H, Hasselwander O, Rautonen N and Ouwehand AC (2009) Panose, a new prebiotic candidate. Lett Appl Microbiol 49(6):666-672

79 Møller MS, Abou Hachem M, Svensson B and Henriksen A (2012) Structure of the starch-debranching enzyme barley limit dextrinase reveals homology of the N-terminal domain to CBM21. Acta Crystallogr F-Struct Biol Cryst Commun 68(Pt 9):1008-12

80 Boraston AB, Bolam DN, Gilbert HJ and Davies GJ (2004) Carbohydrate-binding modules: fine-tuning polysaccharide recognition. Biochem J 382:769-781

81 Guillén D, Sánchez S and Rodríguez-Sanoja R (2010) Carbohydrate-binding domains: multiplicity of biological roles. Appl Microbiol Biotechnol 85(5):1241-1249

82 Lammerts van Bueren A, Ficko-Blean E, Pluvinage B, Hehemann J, Higgins MA, Deng L, Ogunniyi AD, Stroeher UH, El Warry N, Burke RD, Czjzek M, Paton JC, Vocadlo DJ and Boraston AB (2011) The conformation and function of a multimodular glycogen-degrading pneumococcal virulence factor. Structure 19(5):640-651 
83 Xu J, Ren F, Huang C, Zheng Y, Zhen J, Sun H, Ko T, He M, Chen C, Chan H, Guo R, Song H and Ma Y (2014) Functional and structural studies of pullulanase from Anoxybacillus sp. LM18-11. Proteins Struct Funct Bioinf 82(9):1685-1693

84 Gilding EK, Frère CH, Cruickshank A, Rada AK, Prentis PJ, Mudge AM, Mace ES, Jordan DR and Godwin ID (2013) Allelic variation at a single gene increases food value in a drought-tolerant staple cereal. Nat Commun 4:1483

85 Janeček S, Svensson B and MacGregor EA (2011) Structural and evolutionary aspects of two families of non-catalytic domains present in starch and glycogen binding proteins from microbes, plants and animals. Enzyme Microb Technol 49(5):429-440

86 Christiansen C, Abou Hachem M, Janecek S, Vikso-Nielsen A, Blennow A and Svensson B (2009) The carbohydrate-binding module family 20-diversity, structure, and function. FEBS J 276(18):5006-5029

87 Christiansen C, Abou Hachem M, Glaring MA, Vikso-Nielsen A, Sigurskjold BW, Svensson B and Blennow A (2009) A CBM20 low-affinity starch-binding domain from glucan, water dikinase. FEBS Lett 583(7):1159-1163

88 Penninga D, vanderVeen B, Knegtel R, vanHijum S, Rozeboom H, Kalk K, Dijkstra B and Dijkhuizen L (1996) The raw starch binding domain of cyclodextrin glycosyltransferase from Bacillus circulans strain 251. J Biol Chem 271(51):32777-32784

89 Sorimachi K, Le Gal-Coëffet M, Williamson G, Archer D and Williamson M (1997) Solution structure of the granular starch binding domain of Aspergillus niger glucoamylase bound to $\beta$-cyclodextrin. Structure 5(5):647-661

90 Zhu Y, Zhang M, Kelly AR and Cheng A (2014) The carbohydrate-binding domain of overexpressed STBD1 is important for its stability and protein-protein interactions. Biosci Rep 34:311-320

91 Park J, Song H, Jung T, Lee M, Park S, Woo E and Park K (2013) A novel domain arrangement in a monomeric cyclodextrin-hydrolyzing enzyme from the hyperthermophile Pyrococcus furiosus. Biochim Biophys Acta, Proteins Proteomics 1834(1):380-386

92 Liu Y, Lai Y, Chou W, Chang MD and Lyu P (2007) Solution structure of family 21 carbohydrate-binding module from Rhizopus oryzae glucoamylase. Biochem J 40:321-30

93 Abe A, Yoshida H, Tonozuka T, Sakano Y and Kamitori S (2005) Complexes of Thermoactinomyces vulgaris R-47 $\alpha$-amylase 1 and pullulan model oligossacharides provide new insight into the mechanism for recognizing substrates with $\alpha$-(1,6) glycosidic linkages. FEBS J 272(23):6145-6153

94 van Bueren AL, Higgins M, Wang D, Burke RD and Boraston AB (2007) Identification and structural basis of binding to host lung glycogen by streptococcal virulence factors. Nat Struct Mol Biol 14(1):7684

95 Ficko-Blean E and Boraston AB (2012) Insights into the recognition of the human glycome by microbial carbohydrate-binding modules. Curr Opin Struct Biol 22(5):570-577

96 Gourlay LJ, Santi I, Pezzicoli A, Grandi G, Soriani M and Bolognesi M (2009) Group B Streptococcus pullulanase crystal structures in the context of a novel strategy for vaccine development. J Bacteriol 191(11):3544-3552 
97 Lammerts van Bueren A and Boraston AB (2007) The structural basis of $\alpha$-glucan recognition by a family 41 carbohydrate-binding module from Thermotoga maritima. J Mol Biol 365(3):555-560

98 van Bueren A, Finn R, Ausio J and Boraston A (2004) $\alpha$-glucan recognition by a new family of carbohydrate-binding modules found primarily in bacterial pathogens. Biochemistry 43(49):1563315642

99 Machovic M and Janeček S (2008) Domain evolution in the GH13 pullulanase subfamily with focus on the carbohydrate-binding module family 48. Biologia 63(6):1057-1068

100 Polekhina G, Gupta A, van Denderen B, Fell S, Kemp B, Stapleton D and Parker M (2005) Structural basis for glycogen recognition by AMP-activated protein kinase. Structure 13(10):1453-1462

101 Koay A, Woodcroft B, Petrie EJ, Yue H, Emanuelle S, Bieri M, Bailey MF, Hargreaves M, Park J, Park K, Ralph S, Neumann D, Stapleton D and Gooley PR (2010) AMPK beta subunits display isoform specific affinities for carbohydrates. FEBS Lett 584(15):3499-3503

102 Amodeo GA, Momcilovic M, Carlson M and Tong L (2010) Biochemical and functional studies on the regulation of the Saccharomyces cerevisiae AMPK homolog SNF1. Biochem Biophys Res Commun 397(2):197-201

103 Meekins DA, Raththagala M, Husodo S, White CJ, Guo H, Koetting O, Vander Kooi CW and Gentry MS (2014) Phosphoglucan-bound structure of starch phosphatase Starch Excess4 reveals the mechanism for C6 specificity. Proc Natl Acad Sci U S A 111(20):7272-7277

104 Seung D, Soyk S, Coiro M, Maier BA, Eicke S and Zeeman SC (2015) PROTEIN TARGETING TO STARCH is required for localising GRANULE-BOUND STARCH SYNTHASE to starch granules and for normal amylose synthesis in Arabidopsis. PLoS Biol 13(2):1-29

105 Chaen K, Noguchi J, Omori T, Kakuta Y and Kimura M (2012) Crystal structure of the rice branching enzyme I (BEI) in complex with maltopentaose. Biochem Biophys Res Commun 424(3):508-511

106 Feng L, Fawaz R, Hovde S, Gilbert L, Chiou J and Geiger JH (2015) Crystal structures of Escherichia coli branching enzyme in complex with linear oligosaccharides. Biochemistry 54(40):6207-6218

107 Mikami B, Iwamoto H, Malle D, Yoon HJ, Demirkan-Sarikaya E, Mezaki Y and Katsuya Y (2006) Crystal structure of pullulanase: Evidence for parallel binding of oligosaccharides in the active site. J Mol Biol 359(3):690-707

108 Yamashita M, Matsumoto D and Murooka Y (1997) Amino acid residues specific for the catalytic action towards $\alpha$-1,6-glucosidic linkages in Klebsiella pullulanase. J Ferment Bioeng 84(4):283-290

109 Saburi W, Rachi-Otsuka H, Hondoh H, Okuyama M, Mori H and Kimura A (2015) Structural elements responsible for the glucosidic linkage-selectivity of a glycoside hydrolase family 13 exo-glucosidase. FEBS Lett 589(7):865-869

110 Ito K, Ito S, Ishino K, Shimizu-Ibuka A and Sakai H (2007) Val326 of Thermoactinomyces vulgaris R47 amylase II modulates the preference for $\alpha-(1,4)$ - and $\alpha-(1,6)$-glycosidic linkages. Biochim Biophys Acta 1774(4):443-449 
111 Kuriki T, Kaneko H, Yanase M, Takata H, Shimada J, Handa S, Takada T, Umeyama H and Okada S (1996) Controlling substrate preference and transglycosylation activity of neopullulanase by manipulating steric constraint and hydrophobicity in active center. J Biol Chem 271(29):17321-17329

112 Saburi W, Mori H, Saito S, Okuyama M and Kimura A (2006) Structural elements in dextran glucosidase responsible for high specificity to long chain substrate. Biochim Biophys Acta 1764(4):688-698

113 Oslancová A and Janecek S (2002) Oligo-1,6-glucosidase and neopullulanase enzyme subfamilies from the $\alpha$-amylase family defined by the fifth conserved sequence region. Cell Mol Life Sci 59(11):19451959

114 Beatty MK, Rahman A, Cao HP, Woodman W, Lee M, Myers AM and James MG (1999) Purification and molecular genetic characterization of ZPU1, a pullulanase-type starch-debranching enzyme from maize. Plant Physiol 119(1):255-266

115 Tang K, Kobayashi RS, Champreda V, Eurwilaichitr L and Tanapongpipat S (2008) Isolation and characterization of a novel thermostable neopullulanase-like enzyme from a hot spring in Thailand. Biosci Biotechnol Biochem 72(6):1448-1456

116 Elleuche S, Qoura FM, Lorenz U, Rehn T, Brueck T and Antranikian G (2015) Cloning, expression and characterization of the recombinant cold-active type-I pullulanase from Shewanella arctica. J Mol Catal B-Enzym 11:670-677

117 Kang J, Park K, Choi K, Park C, Kim G, Kim D and Cha J (2011) Molecular cloning and biochemical characterization of a heat-stable type I pullulanase from Thermotoga neapolitana. Enzyme Microb Technol 48(3):260-266

118 Kelly A, Diderichsen B, Jorgensen S and Mcconnell D (1994) Molecular genetic analysis of the pullulanase B gene of Bacillus acidopullulyticus. FEMS Microbial Lett 115(1):97-105

119 Albertson G, McHale R, Gibbs M and Bergquist P (1997) Cloning and sequence of a type I pullulanase from an extremely thermophilic anaerobic bacterium, Caldicellulosiruptor saccharolyticus. Biochim Biophys Acta 1354(1):35-39

120 Zeeman SC, Kossmann J and Smith AM (2010) Starch: Its metabolism, evolution, and biotechnological modification in plants. Annu Rev Plant Biol 61:209-234

121 Dinges J, Colleoni C, James M and Myers A (2003) Mutational analysis of the pullulanase-type debranching enzyme of maize indicates multiple functions in starch metabolism. Plant Cell 15(3):666680

122 Burton RA, Jenner H, Carrangis L, Fahy B, Fincher GB, Hylton C, Laurie DA, Parker M, Waite D, van Wegen S, Verhoeven T and Denyer K (2002) Starch granule initiation and growth are altered in barley mutants that lack isoamylase activity. Plant J 31(1):97-112

123 Wattebled F, Dong Y, Dumez S, Delvalle D, Planchot R, Berbezy P, Vyas D, Colonna P, Chatterjee M, Ball S and D'Hulst C (2005) Mutants of Arabidopsis lacking a chloroplastic isoamylase accumulate phytoglycogen and an abnormal form of amylopectin. Plant Physiol 138(1):184-195

124 Wattebled F, Planchot V, Dong Y, Szydlowski N, Pontoire B, Devin A, Ball S and D'Hulst C (2008) Further evidence for the mandatory nature of polysaccharide debranching for the aggregation of 
semicrystalline starch and for overlapping functions of debranching enzymes in Arabidopsis leaves. Plant Physiol 148(3):1309-1323

125 Streb S, Delatte T, Umhang M, Eicke S, Schorderet M, Reinhardt D and Zeeman SC (2008) Starch granule biosynthesis in arabidopsis is abolished by removal of all debranching enzymes but restored by the subsequent removal of an endoamylase. Plant Cell 20(12):3448-3466

126 James M, Robertson D and Myers A (1995) Characterization of the maize gene sugary1, a determinant of starch composition in kernels. Plant Cell 7(4):417-429

127 Nakamura Y, Yuki K, Park S and Ohya T (1989) Carbohydrate-metabolism in the developing endosperm of rice grains. Plant Cell Physiol 30(6):833-839

128 Fujita N, Kubo A, Suh DS, Wong KS, Jane JL, Ozawa K, Takaiwa F, Inaba Y and Nakamura Y (2003) Antisense inhibition of isoamylase alters the structure of amylopectin and the physicochemical properties of starch in rice endosperm. Plant Cell Physiol 44(6):607-618

129 Fujita N, Toyosawa Y, Utsumi Y, Higuchi T, Hanashiro I, Ikegami A, Akuzawa S, Yoshida M, Mori A, Inomata K, Itoh R, Miyao A, Hirochika H, Satoh H and Nakamura Y (2009) Characterization of pullulanase (PUL)-deficient mutants of rice (Oryza sativa L.) and the function of PUL on starch biosynthesis in the developing rice endosperm. J Exp Bot 60(3):1009-1023

130 Li Q, Zhang G, Dong Z, Yu H, Gu M, Sun SSM and Liu Q (2009) Characterization of expression of the OsPUL gene encoding a pullulanase-type debranching enzyme during seed development and germination in rice. Plant Physiol Biochem 47(5):351-358

131 Buléon A, Colonna P, Planchot V and Ball S (1998) Starch granules: structure and biosynthesis. Int J Biol Macromol 23(2):85-112

132 Jeon J, Ryoo N, Hahn T, Walia H and Nakamura Y (2010) Starch biosynthesis in cereal endosperm. Plant Physiol Biochem 48(6):383-392

133 Nakamura Y (2002) Towards a better understanding of the metabolic system for amylopectin biosynthesis in plants: Rice endosperm as a model tissue. Plant cell physiol 43(7):718-725

134 Nakamura Y (1996) Some properties of starch debranching enzymes and their possible role in amylopectin biosynthesis. Plant Sci 121(1):1-18

135 Burton RA, Zhang XQ, Hrmova M and Fincher GB (1999) A single limit dextrinase gene is expressed both in the developing endosperm and in germinated grains of barley. Plant Physiol 119(3):859-871

136 Janulczyk R and Rasmussen M (2001) Improved pattern for genome-based screening identifies novel cell wall-attached proteins in gram-positive bacteria. Infect Immun 69(6):4019-4026

137 Kim J, Kim H, Lim M, Ko H, Chin J, Lee HB, Kim I and Bai S (2010) Construction of a direct starchfermenting industrial strain of Saccharomyces cerevisiae producing glucoamylase, $\alpha$-amylase and debranching enzyme. Biotechnol Lett 32(5):713-719

138 Doman-Pytka M and Bardowski J (2004) Pullulan degrading enzymes of bacterial origin. Crit Rev Microbiol 30(2):107-121

139 Hii SL, Tan JS, Ling TC and Ariff AB (2012) Pullulanase: Role in starch hydrolysis and potential industrial applications. Enzyme Research 2012:1-14 
140 Kelly RM, Dijkhuizen L and Leemhuis H (2009) Starch and $\alpha$-glucan acting enzymes, modulating their properties by directed evolution. J Biotechnol 140(3-4):184-193

141 van der Maarel M, van der Veen B, Uitdehaag J, Leemhuis H and Dijkhuizen L (2002) Properties and applications of starch-converting enzymes of the $\alpha$-amylase family. J Biotechnol 94(2):137-155

142 Haki G and Rakshit S (2003) Developments in industrially important thermostable enzymes: a review. Bioresour Technol 89(1):17-34

143 Goffin D, Delzenne N, Blecker C, Hanon E, Deroanne C and Paquot M (2011) Will isomaltooligosaccharides, a well-established functional food in Asia, break through the European and American market? The status of knowledge on these prebiotics. Crit Rev Food Sci Nutr 51(5):394-409

144 Mussatto SI and Mancilha IM (2007) Non-digestible oligosaccharides: A review. Carbohydr Polym 68(3):587-597

145 Vester-Christensen MB, Abou Hachem M, Svensson B and Henriksen A (2010) Crystal structure of an essential enzyme in seed starch degradation: Barley limit dextrinase in complex with cyclodextrins. J Mol Biol 403(5):739-750

146 Møller MS, Vester-Christensen MB, Jensen JM, Abou Hachem M, Henriksen A and Svensson B (2015) Crystal structure of barley limit dextrinase-limit dextrinase inhibitor (LD-LDI) complex reveals insights into mechanism and diversity of cereal type inhibitors. J Biol Chem 290(20):12614-12629

147 Turkenburg JP, Brzozowski AM, Svendsen A, Borchert TV, Davies GJ and Wilson KS (2009) Structure of a pullulanase from Bacillus acidopullulyticus. Proteins Struct Funct Bioinf 76(2):516-519

148 Malle D, Itoh T, Hashimoto W, Murata K, Utsumi S and Mikami B (2006) Overexpression, purification and preliminary X-ray analysis of pullulanase from Bacillus subtilis strain 168. Acta Crystallogr, Sect F: Struct Biol Cryst Commun 62:381-384

149 Hondoh H, Kuriki T and Matsuura Y (2003) Three-dimensional structure and substrate binding of Bacillus stearothermophilus neopullulanase. J Mol Biol 326(1):177-188

150 Kamitori S, Kondo S, Okuyama K, Yokota T, Shimura Y, Tonozuka T and Sakano Y (1999) Crystal structure of Thermoactinomyces vulgaris R-47 $\alpha$-amylase II (TVAII) hydrolyzing cyclodextrins and pullulan at 2.6 ̊̊ resolution. J Mol Biol 287(5):907-921

151 Kondo S, Ohtaki A, Tonozuka T, Sakano Y and Kamitori S (2001) Studies on the hydrolyzing mechanism for cyclodextrins of Thermoactinomyces vulgaris R-47 $\alpha$-amylase 2 (TVAII). X-ray structure of the mutant E354A complexed with $\beta$-cyclodextrin, and kinetic analyses on cyclodextrins. J Biochem 129(3):423-428

152 Ohtaki A, Kondo S, Shimura Y, Tonozuka T, Sakano Y and Kamitori S (2001) Role of Phe286 in the recognition mechanism of cyclomaltooligosaccharides (cyclodextrins) by Thermoactinomyces vulgaris R-47 $\alpha$-amylase 2 (TVAII). X-ray structures of the mutant TVA11s, F286A and F286Y, and kinetic analyses of the Phe286-replaced mutant TVAIIs. Carbohydr Res 334(4):309-313

153 Kamitori S, Abe A, Ohtaki A, Kaji A, Tonozuka T and Sakano Y (2002) Crystal structures and structural comparison of Thermoactinomyces vulgaris R-47 $\alpha$-amylase 1 (TVAI) at $1.6 \AA$ resolution and $\alpha$-amylase 2 (TVAII) at 2.3 Å resolution. J Mol Biol 318(2):443-453 
154 Yokota T, Tonozuka T, Shimura Y, Ichikawa K, Kamitori S and Sakano Y (2001) Structures of Thermoactinomyces vulgaris R-47 $\alpha$-amylase II complexed with substrate analogues. Biosci Biotechnol Biochem 65(3):619-626

155 Mizuno M, Tonozuka T, Uechi A, Ohtaki A, Ichikawa K, Kamitori S, Nishikawa A and Sakano Y (2004) The crystal structure of Thermoactinomyces vulgaris R-47 $\alpha$-amylase II (TVA II) complexed with transglycosylated product. Eur J Biochem 271(12):2530-2538

156 Ohtaki A, Mizuno M, Tonozuka T, Sakano Y and Kamitori S (2004) Complex structures of Thermoactinomyces vulgaris $\mathrm{R}-47$-amylase 2 with acarbose and cyclodextrins demonstrate the multiple substrate recognition mechanism. J Biol Chem 279(30):31033-31040

157 Watanabe K, Hata Y, Kizaki H, Katsube Y and Suzuki Y (1997) The refined crystal structure of Bacillus cereus oligo-1,6-glucosidase at $2.0 \AA$ resolution: Structural characterization of proline-substitution sites for protein thermostabilization. J Mol Biol 269(1):142-153

158 Hondoh H, Saburi W, Mori H, Okuyama M, Nakada T, Matsuura Y and Kimura A (2008) Substrate recognition mechanism of $\alpha$-1,6-glucosidic linkage hydrolyzing enzyme, dextran glucosidase from Streptococcus mutans. J Mol Biol 378(4):913-922

159 Tamura K, Stecher G, Peterson D, Filipski A and Kumar S (2013) MEGA6: Molecular Evolutionary Genetics Analysis version 6.0. Mol Biol Evol 30(12):2725-2729

160 Ilinkin I, Ye J and Janardan R (2010) Multiple structure alignment and consensus identification for proteins. BMC Bioinformatics 11:1-8

161 Pei J, Kim B and Grishin NV (2008) PROMALS3D: a tool for multiple protein sequence and structure alignments. Nucleic Acids Res 36(7):2295-2300

162 Robert X and Gouet P (2014) Deciphering key features in protein structures with the new ENDscript server. Nucleic Acids Res 42(W1):W320-W324 


\section{TABLES}

Table 1. Overview of the $\alpha$-glucan debranching enzymes covered in the present review. See Tables S1 and S2 for details on kinetic constants and relative specific activities of characterised GH13_11-14, GH13_39, and GH57.

\begin{tabular}{|c|c|c|}
\hline $\begin{array}{l}\text { GH } \\
\text { family }\end{array}$ & Enzyme name & $\begin{array}{l}\text { Glucosidic linkage specificity and } \\
\text { substrate preference }\end{array}$ \\
\hline \multirow[t]{2}{*}{$13 \_11$} & Isoamylase (ISA) & $\begin{array}{l}\alpha-1,6 \text { (amylopectin and derived branched } \\
\text { maltooligosaccharides) }\end{array}$ \\
\hline & Glycogen debranching enzyme (GDE) & $\alpha-1,6$ (glycogen and amylopectin) \\
\hline \multirow[t]{2}{*}{$13 \_12$} & Pullulanase type I (PULI) & $\begin{array}{l}\alpha-1,6 \text { (amylopectin and derived branched } \\
\text { maltooligosaccharides and pullulan) }\end{array}$ \\
\hline & Pullulanase type II with two catalytic domains (PULII_II) & $\begin{array}{l}\alpha-1,4 \text { and } \alpha-1,6 \text { (starch, starch derivatives } \\
\text { and pullulan) }\end{array}$ \\
\hline $13 \_13$ & Pullulanase type I/limit dextrinase (PULI) & $\begin{array}{l}\alpha-1,6 \text { (amylopectin derived branched } \\
\text { maltooligosaccharides and pullulan) }\end{array}$ \\
\hline \multirow[t]{2}{*}{$13 \_14$} & Pullulanase type I (PULI) & $\begin{array}{l}\alpha-1,6 \text { (amylopectin and derived branched } \\
\text { maltooligosaccharides and pullulan) }\end{array}$ \\
\hline & Pullulanase type II with two catalytic domains (PULII_II) & $\begin{array}{l}\alpha-1,4 \text { and } \alpha-1,6 \text { (starch, starch derivatives } \\
\text { and pullulan) }\end{array}$ \\
\hline $13 \_20$ & Pullulan hydrolase/maltogenic $\alpha$-amylase & $\begin{array}{l}\alpha-1,4 \text { and } \alpha-1,6 \text { (starch, starch derivatives, } \\
\text { pullulan and } \beta \text {-cyclodextrin) }\end{array}$ \\
\hline $13 \_31$ & Oligo- and glucan-1,6- $\alpha$-glucosidase & $\begin{array}{l}\alpha-1,6 \text { (linear isomaltooligosaccharides, } \\
\text { panose and dextran) }\end{array}$ \\
\hline $13 \_39$ & Pullulanase type II with one catalytic domain (PULII_I) & $\begin{array}{l}\alpha-1,4 \text { and } \alpha-1,6 \text { (starch and derivatives and } \\
\text { pullulan) }\end{array}$ \\
\hline $13 \_41$ & Pullulanase type II with two catalytic domains (PULII_II) & $\begin{array}{l}\alpha-1,4 \text { and } \alpha-1,6 \text { (starch and derivatives and } \\
\text { pullulan) }\end{array}$ \\
\hline 57 & Pullulanase type II with one catalytic domain (PULII_I) & $\begin{array}{l}\alpha-1,4 \text { and } \alpha-1,6 \text { (starch and derivatives and } \\
\text { pullulan) }\end{array}$ \\
\hline
\end{tabular}

Table 2. Overview of the published crystal structures of GH13 $\alpha$-glucan debranching enzymes.

\begin{tabular}{|c|c|c|c|c|c|}
\hline GH subfamily & Organism & $\begin{array}{l}\text { PDB } \\
\text { entry }\end{array}$ & Ligand(s) in active site & $\begin{array}{l}\text { Resolu- } \\
\text { tion (Å) }\end{array}$ & References \\
\hline 13_11 & Chlamydomonas reinhardtii $\mathrm{CC} 425$ & $4 J 7 R$ & None & 2.3 & [16] \\
\hline \multirow[t]{6}{*}{ ISĀs and GDEs } & & 4OKD & Maltoheptaose & 2.4 & \\
\hline & $\begin{array}{l}\text { Escherichia coli } \text { str. K-12 substr. } \\
\text { MG1655 }\end{array}$ & $2 \mathrm{WSK}$ & None & 2.25 & [19] \\
\hline & $\begin{array}{l}\text { Pseudomonas amyloderamosa SB- } \\
15\end{array}$ & $1 \mathrm{BF} 2$ & None & 2.0 & [29] \\
\hline & Sulfolobus solfataricus $\mathrm{P} 2$ & $2 \mathrm{VNC}$ & None & 3.0 & {$[30]$} \\
\hline & & 2VR5 & Acarbose & 2.8 & \\
\hline & & 2VUY & None & 3.0 & \\
\hline \multirow{5}{*}{$\begin{array}{l}\text { 13_12 } \\
\text { PULIs }\end{array}$} & Streptococcus agalactiae & 3FAW & None & 2.1 & [96] \\
\hline & & 3FAX & $\begin{array}{l}\text { Maltotetraose (only } 3 \\
\text { glucose units solved) }\end{array}$ & 2.4 & \\
\hline & Streptococcus pneumoniae & $2 \mathrm{YA} 0$ & None & 1.85 & {$[82]$} \\
\hline & & 2YA1 & $2 \times$ maltotetraose & 2.25 & \\
\hline & & 2YA2 & G-moranoline & 2.37 & \\
\hline 13_13 & Hordeum vulgare, barley & $4 \mathrm{AIO}$ & None & 1.9 & {$[36,79$,} \\
\hline \multirow[t]{7}{*}{ PŪLIs } & & $2 \mathrm{Y} 4 \mathrm{~S}$ & $\beta$-cyclodextrin & 2.1 & $145,146]$ \\
\hline & & $2 \mathrm{Y} 5 \mathrm{E}$ & $\alpha$-cyclodextrin & 2.49 & \\
\hline & & $4 \mathrm{CVW}$ & Proteinaceous inhibitor & 2.67 & \\
\hline & & $4 \mathrm{~J} 3 \mathrm{~S}$ & Maltotriose + maltotetraose & 1.75 & \\
\hline & & $4 \mathrm{~J} 3 \mathrm{~T}$ & Maltotetraose & 1.6 & \\
\hline & & $4 \mathrm{~J} 3 \mathrm{U}$ & Maltosyl-S- $\beta$-cyclodextrin & 1.7 & \\
\hline & & $4 \mathrm{~J} 3 \mathrm{~V}$ & & 1.45 & \\
\hline
\end{tabular}




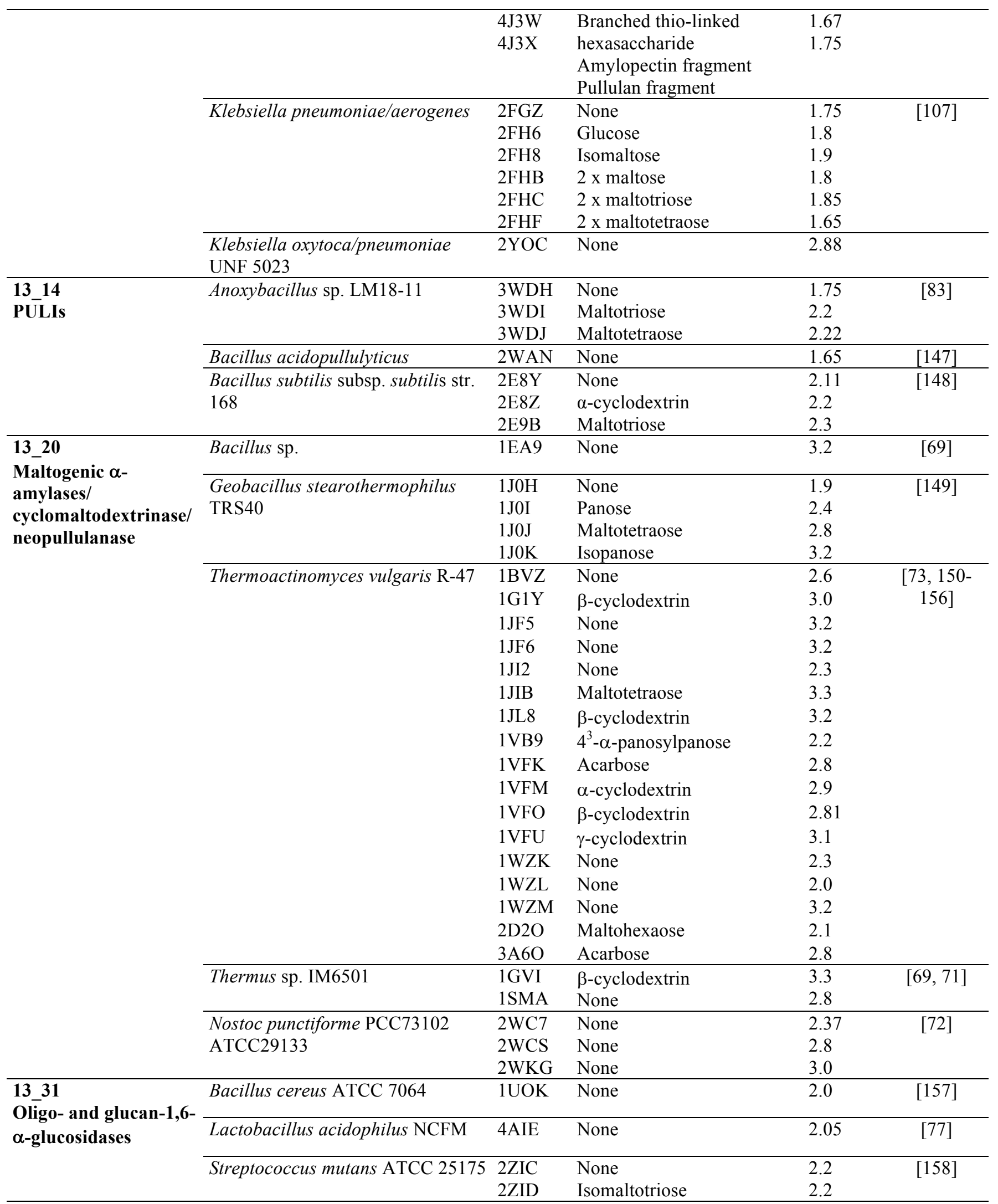




\section{FIGURES}

Fig. 1. Basic structural motifs of the $\alpha$-glucan substrates amylopectin (a), glycogen (b), and pullulan (c).

Fig. 2. Domain organization (top) of the structure-determined $\alpha$-glucan debranching enzymes and overall structure of selected GH13_11 and GH13_12-14 (bottom). The domain assignment and the residue numbering are according to the literature references for the structures (see Table 1). Some of domain assignments have been updated according to CAZy [4] and in the cases where there was no primary reference for the structure, the domains have been assigned based on superimposition with other related structures. An asterisk indicates domains lacking in the crystal structures. The colour code of the structures follows the domain organisation overview. Ligands (grey) are shown as stick representation, while catalytic residues (black) are shown as spheres.

Fig. 3. Phylogenetic tree including enzymatically characterised enzymes from GH13 $\alpha$-glucan debranching subfamilies (see Figure S1 for associated multiple sequence alignment). The phylogenetic tree was made using the Maximum Likelihood method in MEGA6 [159], and it was based on a multiple protein sequence alignment including the catalytic domain of biochemically characterised enzymes from GH13_11 (9 sequences), GH13_12 (5, including two assigned as well to GH13_41), GH13_13 (8), GH13_14 (14), GH13_20 (12), GH13_31 (9), GH13_39 (10), and GH13_41 (44 - i.e. all available sequences assigned to this subfamily having a pullulanase domain), which was built using muscle in MEGA6 [159]. The catalytic domains were extracted based on CDD domain assignments (AmyAc_Glg_debranch, AmyAc_Pullulanase_LD-like, AmyAc_CMD, AmyAc_SI_OligoGlu_DGase) [15], while only the pullulanase catalytic domains were included in the case of PULII_IIs.

Fig. 4. Sections of a structure-guided multiple protein sequence alignment including all structures mentioned in Table 1 and the catalytic pullulanase domain from GH13_12 of selected characterised PULII_IIs from and GH13_39 PULII_Is (see Figure S2 for full alignment). The order of the protein sequences is as aligned by the applied Promals3D alignment algorithm. The consensus structure of the catalytic domain (grey ribbon; catalytic residues are shown as sticks) was generated based on the structures included in the alignment using MAPSCI [160]. Regions I-IV refer to the four conserved motifs of all GH13 proteins [6]. Regions V-VII are additional specificity motifs. The general motifs are given below regions I-IV: X, usually a hydrophobic residue; $\mathrm{B}$, usually a hydrophilic residue; $\mathrm{Z}$, a residue important for specificity [6]. The catalytic residues are indicated by asterisks, while green dashed boxes indicate residues of special interest and mentioned in the discussion. The structure guided alignment was generated using Promals3D [161] and visualised using ESPript $3.0[162]$.

Fig. 5. Active site architecture of $\alpha$-glucan debranching enzymes. a GH13_11 (PDB entry 4OKD); b GH13_13 (PDB entry 4J3W); c GH13_20 (PDB entry 1J0J); and d GH13_31 (PDB entry 2ZID). Ligands from the respective structures are shown as sticks. 
Fig. 6. Differences and similarities of the structure determined $\alpha$-glucan debranching GH13 enzymes. See text for description of specific residues labelled in the multipanel figure. a Superimposition of the catalytic residues and ligands at subsite -1 of representative structures of $\alpha$-glucan debranching GH13 enzymes: GH13_11 (PDB entries 4J7R and 4OKD; maltoheptaose, pink), GH13_13 (PDB entries 4AIO, 4J3W, and 4J3X; $6^{2}$ - $\alpha$-Dmaltotriosyl-maltotriose, blue; $6^{3}$ - $\alpha$-D-glucosyl-maltotriosyl-maltotriose, limon), GH13_20 (PDB entries 1BVZ and 1VB9; $4^{2}$ - $\alpha$-panosyl-panose, cyan), GH13_20 (PDB entries 1J0H and 1J0J; maltotetraose, purple), and GH13_31 (PDB entries 2ZIC and 2ZID; isomaltotriose, orange). b Superimposition of region II including the branched ligand from PDB entry 4J3W (blue sticks) representative structures from GH13 subfamilies 11 (PDB entries 4J7R and 2VNC; pink and green), 12 (PDB entry 2YA0, wheat), 13 (PDB entry 4AIO, blue), 14 (PDB entry 2E8Y, light blue), 20 (PDB entries 1J0H and 2WC7; purple and white), and 31 (PDB entry 2ZIC; orange). c Superimpositions of amino acid resides equal to Val195 of the Streptococcus mutans GH13_31 enzyme (colour code as for $\mathbf{b}$ ). The maltopentaose from a Bacillus subtilis $\alpha$-amylase (PDB entry 1BAG, teal sticks) and the branched ligand from the GH13_13 limit dextrinase from barley (PDB entry 4J3W, blue sticks) are included for labelling of subsites. d Superimposition of region III of the same structures as in $\mathbf{b}$ (only exception is that PDB entry $2 \mathrm{E} 8 \mathrm{Z}$ is used instead of $2 \mathrm{E} 8 \mathrm{Y}$ ), with special focus on the tryptophan stacking with the glucose unit in subsite +2 . e Superimposition of region IV including same structures as in b. f Superimposition of region VII of all GH13_11 structures (cyan sticks) and representative GH13_12-14 structures (PDB entries 2YA0, 4AIO, and 2E8Y; orange sticks) including the pullulan fragment from PDB entry 4J3X (limon sticks) and the maltoheptaose from PDB entry 4OKD. All structure visualisations were made using PyMOL (The PyMOL Molecular Graphics System, Version 1.7.4 Schrödinger, LLC). 


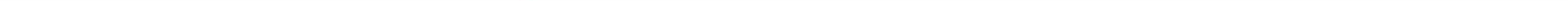




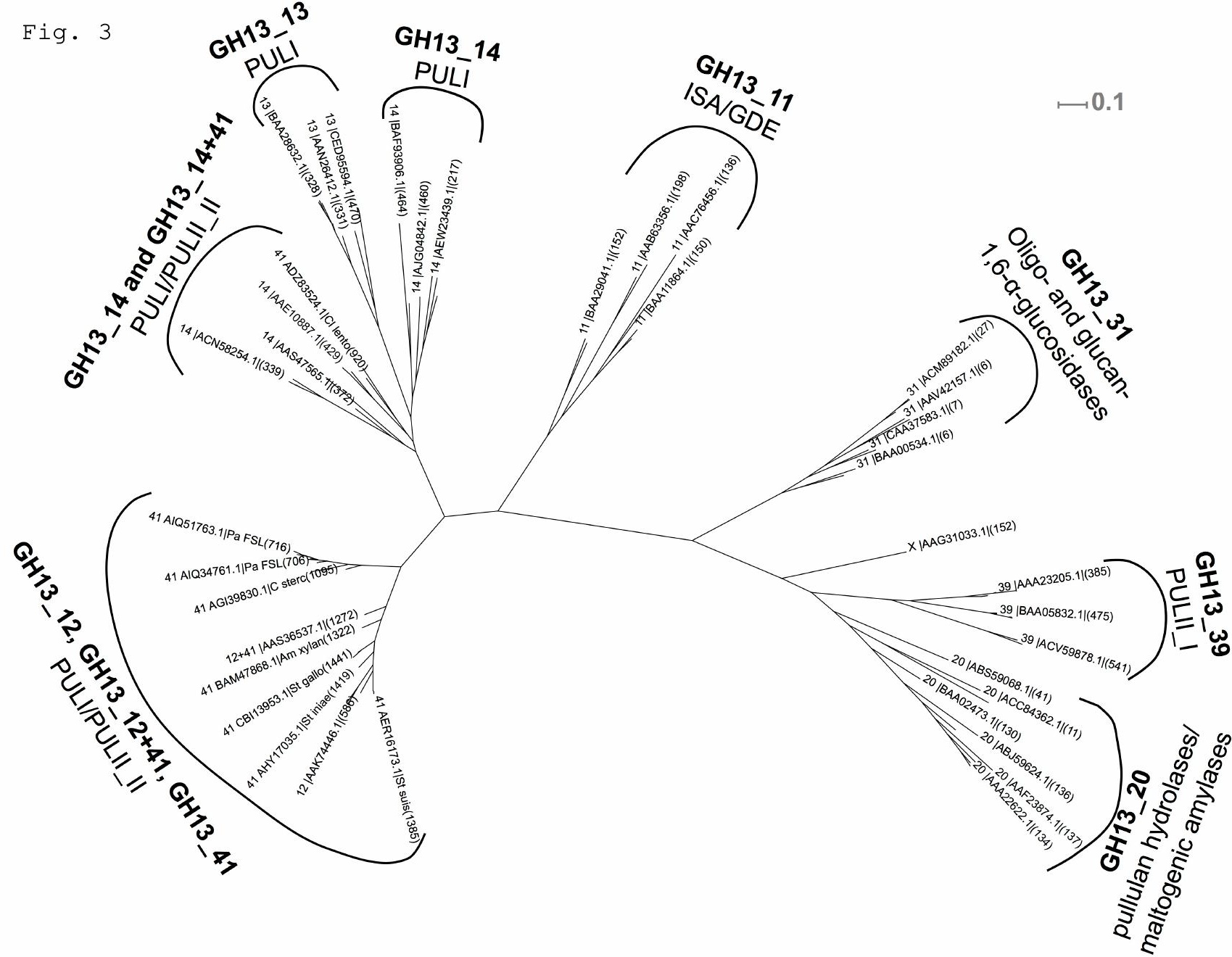


Figure S1

Full multiple sequence alignment of the catalytic domains from alpha-glucan debranching enzymes used for generating the phylogenetic tree in Fig. 3. The number after the GenBank accession number refers to the residue number at which the catalytic domain was defined to start from.

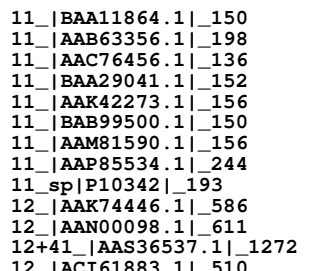

$12+41$ | AAS 36537.1 I-1272

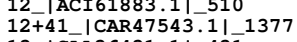

13_ICAA36431.11|431

13-IAAA25124.1|-443

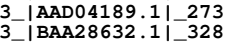

_IAAD11599.1 330

3_|AAN2 6412.1|_331

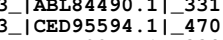

|ACN58254.1|_ 339

BAB62095.11-218

4_IBAF 93906.1 1 - 464

4_IAAY89038.1 I-1075

4_IAFL46505.1 1 -460

14_|AJG0 4842.1 1 -460

14_|AAD 30387.1|-347_2

14_ICAC85704.1|_218

14_|AEW23439.1|_217

4_|CAC60156.1|_ 431

14_IAAE10887.1|_429

14-|AAC00283 $11 \mid \mathbf{2} 2$

14_|AAD 36907| 339

20_|BAA02473.1|_130

20-|AAA22622.1|-134

- AAC15072.1|-134

- AAF23874.1I_137

(A)

ABS59068.11-41

ACC 84362.1 .

|BAI67607.11

|AFM4 3699.1 1 - 134

|AHW51935.1|-133

1_ICAA37583.1|_

1_ |BAA00534.1|-6

| BAA11354.1|_6

AAV42157.1 6

AAV72157.1 6

1_|ACM89182.1|_27

31_|ACM89183.1|_26

39-|AAA23205.1 1 - 385

39-|AAA1 9800.1 1 -388

39_|BAA05832.1|_475

39_|ABR2 6448.1 _ 397

9_|ABY95795.1|_385

9. IACR15165.1 1 - 384

-IADZ99363.1| 550

1_AHY15164.1|St iniae 1419

41_AGL48789.1 1 St suis 1378

41_AHY17035.1|St_iniae 1419

41_AGZ24199.1 |St_suis_1377

41_ABP93225.1 | St_suis_1252

41_AER20299.1 | St_suis_1389

41_ADZ83524.1|C1_lento_920

41_AGW88268.1|St_suis_1385

41_AGG65362.1 St_suis_138

41 ADV71067.1 St suis 1385

41_AER16173.1 ISt suis 1385

41_AIQ51763.1|Pa_FSL_716

41_CBI13953.1| St_gallo_1441

41_CAZ56775.1 ISt_suis_1377

41_AIQ34761.1 |Pa_FSL_706

41_CCF02755.1 | St_maced_1180

41_CB248657.1|St_gallo_1441

41_AIQ57390.1 | Pa_borea_723

41 AEB82319.1ISt suis 1385

41_BAM47868.1|Am_xylan_1322

41_AFR01291.1 | St_suis_1385

1.1 St_suis_140

41 AHF 603

41_CAZ52647.1|St_suis_1377
41_ACX81318.1|St_gallo 1452

41_ACX81318.1 | St_gallo_1452

41_ABG83674.1 CI_perfr_883

41_BAK28316.1 ISt_gallo_1441

AGX6343.1 Ba infan 1304

41_AIQ22910.1 Pa_FSL 700

41_AIQ67951.1|Pa_grami_717

41_AIQ16995.1|Pa_FSL 716

41_AER18240.1|St_suis_1385

41_AIQ46154.1|Pa_FSL_716

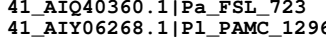

41_AIY06268.1|P1 $\begin{array}{llll}10 & 20 & 30 & 40\end{array}$

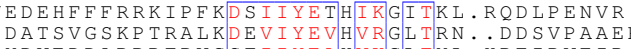

DATSVGSKPTRA L REVIYEVHVRGITRN. D D SVPAAER
YDWEDDAPPRTPWGSTIIYEAHVKGLTYL. HPEIPVEIR.

. FDWQGDLPLRYPQKDLVIYEMHLRGETKH. . . SSSNVEHP.

EEWDDEDFIKGKKVPLKDTVIYEVHVKGETKL. RLDLPENIR .

... DWGNDRAPRIPYNETVIYEAHVKGMTMT. HPDVPEELR.

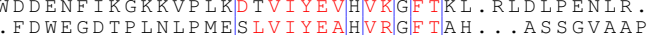

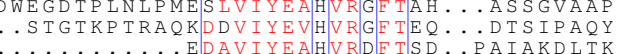

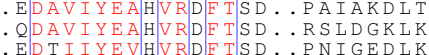

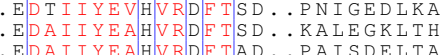

MT I HESHT DDISAW. DOTVPA.

. MTIHESHIRDISAW. DOTVPAELR.

D ISIYELHIRDFSAH. . DS TVDCNSR.

D IS IYELHIRDESAH..DSTVDCPFR...

.

EDAVIYEGHIRDESIR..DQSTSAAHR .

TDAIIYeLSIRDETSH . . PDSGAVHK

EDA I IYEIHIADMTG …… DN S GVKNK

TDAIITEANVRDMTIN. . PNS GVSEAN

DAIIYEMVRDETID.QSSGIGENLR.

TDA I IYESHVRDL S MF..DVTNSGYDS

EDAIIYEIHIADMTGL...DNSGVKNK...

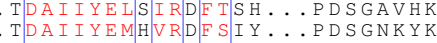

. HESGVRQK

ANSGMKNK

PNSGMKN

EN S GMINK
PNSGMKNK

ENSGV..KN

. DPSNDPPGT

NPS I SPEGSR

NEA LNPAGT I.

NPAISPKGAR

NPSISPEGSR

DRRNDPKAA

KQPRKRLLQE

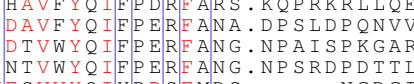

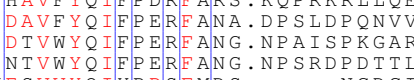

KESVVYQIYPRSEMDS ......NGDGI

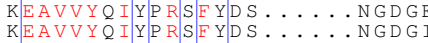

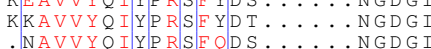

KNAVVYQVYPRSSEQDS........NGDG

NAVVYQIYPRSEQDT.........NGDGE .NGD

D S SNDHLKK

NPNNDKVKE.

NPNNDKVKK

NP SNDNSKQ

DP LNDRLKE.

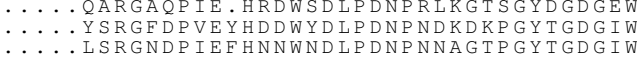

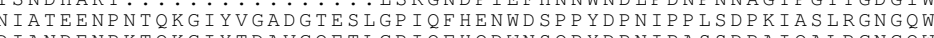

...

NPSNDNSKQ.

VA ISSQLK
PAISDELT

VAIS SQLKN

PAISDELTA.

PAISDELTA.

PAISDELTA
PAISDELTA.

PNAPFINK

P A I SDELTA

PAIQSSLGG.

PAISDELTA.

VAIESELGA.

TA I SDELQH

VSIVDSLSG.

TA I SEELRN

TA I SDELQH
TAISDELQH

PAIQSSLGG.

PAISDELTA.

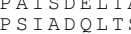

PAISDELTA.

VAISSQLKN

PAISDELTA
PAISDELTA.

PAISDELTA.

TAISDELQH

.

TA I S DELQH

TAISDELQH
VSIESELGG

PSIEADLNS

VSIEDSLSG

ISIESELGG

PAISDELTA.

VSIESSLNG.

PAIQSSLGG

. DPSNDLKA.
QARGAOPIE.HRDWSDLPDNPRLKGTSGDGDGEW SRGNDPIEFHNDWNDLPDNPNNAGTPGYTGDGIW
YSRGEDPVEYHSNWYELPDNPNDKNKLGYTGDGIW 
11_|BAA11864.1|_150

11_IAAC76456.1_-198

11_|BAA29041.1| 152

1_|AAK42273.1| 156

|BAB99500.1| 150

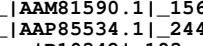

Sp|P10342|_193

|AAK74446.11 586

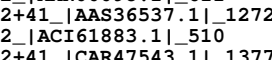

2+41_|CAR47543.1| 1377

3_|AAA25124.1|_ 443

- IAAD0 4189.1|_ 273

\begin{tabular}{|l|l|}
$\mid$ | AAD 11599.1 & 330 \\
\hline AAN2 6412.1 & 331
\end{tabular}

\begin{tabular}{l}
$3-\mid$ AAN2 6412.1 \\
3_IABL84490.1 331 \\
\hline
\end{tabular}

C

ACN58254.1 339

BAB62095.1I_218

4_|BAF 93906.1 | 464

4_IAAY89038.1|_1075

|AAB0 6264.11 330

|AJG0 4842.1|_460

4_|AAD 30387.1 |-347_2

14_ICAC85704.1|_-218

IAAS4 7565.1I_372

ICAC60156.1I 431

(CAC60156. 431

AAAC00283 1 - 213

4_ICAC60157i_429

|BAA02473.1| 130

|AAA2 2622.1|_134

|AAC4 6346.1|_134

IAAC15072.1 1 134

|AAK15003.1|_134

ABBJ59624.1|_136

|ABS59068.1|-41

|ACC84362.1|_1

|BAI 67607.11 9

AHW51935.1 _ 133

ICAA37583.1I 7

|BAA00534.1|_6

|BAA01368.11 7

BAA11354.1|-6
AAKK27723.1|_24

|AAV42157.1|_6

ACM89182.11-27

31_|ACM89183.1 26

39-|AAA23205.1|-385

39-|AAA1 9800.1 388

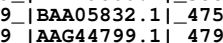

|ABR2 6448.1|_397

9-|ABY95795.1| 385

|ACV15165.11 384

|ADZ99363.1| 550

41_AHY15164.1|St_iniae_1419

41_AGL48789.1 ISt_suis_1378

41_AHY17035.1 ISt_iniae_1419

41_AGZ24199.1 | St_suis_1377

41_ABP93225.1 | St_suis_1252

41_AER22304.1 ISt_suis_1385

41_ADZ83524.1|Cl_lento_920

41_AGW88268.1 ISt_suis_1385

41_AI028595.1

41 ADV71067.1 St suis 1385

41_AER16173.1 ISt_suis_1385

41_AIQ51763.1 |Pa_FSL_716

41_CBI13953.1 | St_galilo_1441

41_CAZ56775.1 | St_suis_1377

41_AIQ34761.1 |Pa_FSL_706

41_CCF02755.1 I St_maced_1180

41_CBZ48657.1|St_gallo_1441

41_AIQ57390.1 | Pa_borea_723

41 AEB82319. 1 St suis 1385

41 BAM47868.1 Am xylan 132

41_AFR01291. 1 | St suis 1385

41_AGM98096.1 |St_iniae 1419

41_ADE32331.1 | St_suis_1408

41_AHF 60382.1 | St_suis_1385

41_CAZ52647.1|St_suis_1377
41_ACX81318.1|St_gallo_1452

41_ACX81318.1|St_gallo_145

41_ABG83674.1 C1

41_BAK28316.1 | St_gallo_1441

41 AGX06343.1 Ba infan 1304

41_AIQ22910.1 Pa_FSL_700

41_AIQ67951.1|Pa_grami_717

41_AIQ16995. 1 |Pa_FSL 716

41_AER18240.1 | St_suis_1385

41_AIQ46154.1|Pa_FSL_716

41_AIQ40360.1 |Pa_FSL_723
41_AIY06268.1 | PI PAMC 129

41_AIY06268.1|P1_PAM

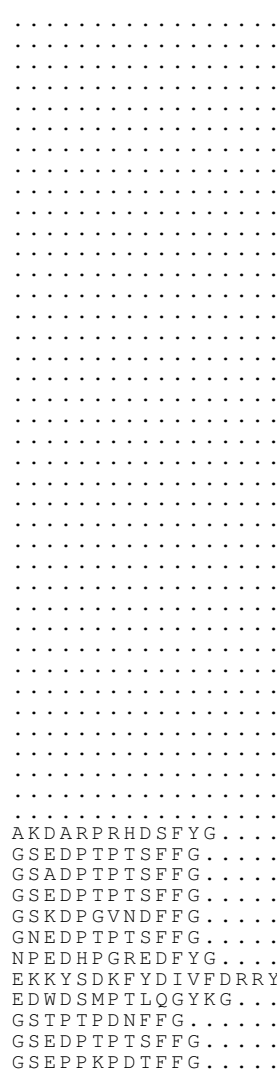

SNDFFG.

NNDFFG.

SNDFFG.

SNDFFG

SNDFFG.

IIDFF

SNDFFG.

$\cdots$

D GPVTS L HC C Q Y F
50

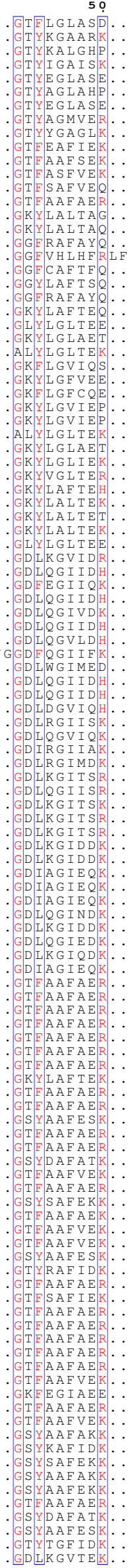

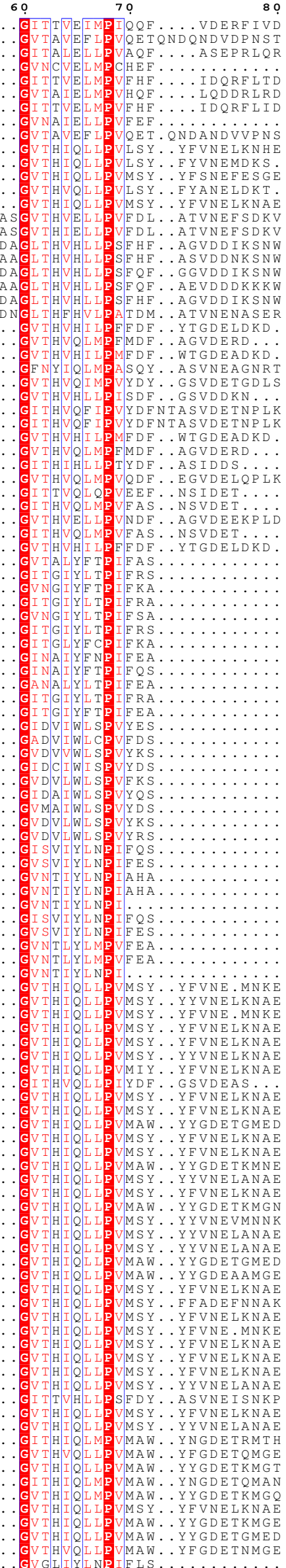


11_|BAA11864.1|_150

11_IAAC76456.1_136

11_|BAA29041.1| 152

1_|AAK42273.1|_156

|BAB99500.1| 150

\begin{tabular}{l} 
|AAM81590.1|_156 \\
|AAP85534.1 \\
\hline
\end{tabular}

sp|P10342 | 193

|AAK74446.1|_586

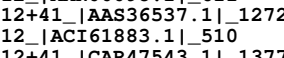

12+41-ICAR47543.1| 1377

3_|AAA25124.1 1 -443

- IAAD0 4189.1|_ 273

|AAD11599.1|_330

|AAN2 6412.1| 1 - 331

CED $9594.11-470$

ACN58254.11_339

BAB62095.1I_218

|BAF93906.1 1 -464

|AAY89038.1|_1075

|AAB0 6264.1 330

$\mid$ AFL 46505.1
A 1

4_IAAD 30387.1 |-347_2

4_ICAC85704.1| 218

IAAS4 7565.1I_372

CAC60156.11-431

IAAE10887.1 431

- AAC00283.1 429

4_ICAC60157i_429

|BAA02473.1| 130

|AAA22 622.1| 134

AAC4 6346.1 1

|AAC15072.1|-134

|AAK15003.1|_134

ABJ59624.1 136

ABJ59624.11-136

ACC84362.1 11

|BAI67607.11_9

|AFM4 3699.1|_134

ICAA37583.1|-

| BAA00534.1|_6
|BAA01368.1|_7

|BAA11354.1| 6

|AAV42157.1|_6

AAV72157.1 6

|ACM89182.1|_27

31_|ACM89183.1|_26

39-|AAA23205.1|-385

39_|AAA1 9800.1 1 -388

39_|BAA0 5832.1|_475

39_|ABR2 6448.1|_397

9_IABY 95795.1|_385

39-IACR15165.1|-384

-IADZ99363.1| 550

1_AHY15164.1|St iniae 1419

41_AGL48789.1|St_suis_1378

41_AHY17035.1 ISt_iniae_1419

41_AGZ24199.1 | St_suis_1377

41_ABP93225.1 | St_suis_1252

41_AER22304.1|St_suis_1385

41_ADZ83524.1|Cl_lento_920

41_AGW88268.1 | St_suis_1385

41_AI028595.

41 ADV71067.1 St suis 1385

41_AER16173.1 |St_suis_1385

41_AIQ51763.1 | Pa_FSL_716

41_CBI13953.1 i St_gallo_1441

41_CAZ56775.1 I St_suis_1377

41_AIQ34761.1 |Pa_FSL_706

41_CCF02755.1 I St_maced_1180

41_CB248657.1|St_gallo_1441

1_AIQ57390.1 Pa_borea_723

41 AEB82319.1 ISt suis 1385

41 BAM47868.1 |Am xylan 132

41_AFR01291.1 St suis 1385

41_AGM98096.1 | St_iniae_1419

41_ADE32331.1 |St_suis_1408
41_AHF60382.1 St_suis_1385
41_CAZ52647.1 St_suis_1377

41_CAZ52647.1|St_suis_1377
41_ACX81318.1|St_gallo_1452

41_ACX81318.1 | St_gallo_1452

41_ABG83674.1 CI_perfr_883

41_BAK28316.1 | St_gallo_1441

41 AGX6343 1 Ba infan 1304

41_AIQ22910.1 Pa_FSL 700

41_AIQ67951.1 Pa_grami_717

41_AIQ16995. 1 |Pa_FSL 716

41_AER18240.1 |St_suis_1385

41_AIQ46154.1 | Pa_FSL_716

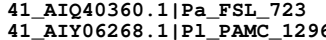

41_AIY0 6268.1|PI

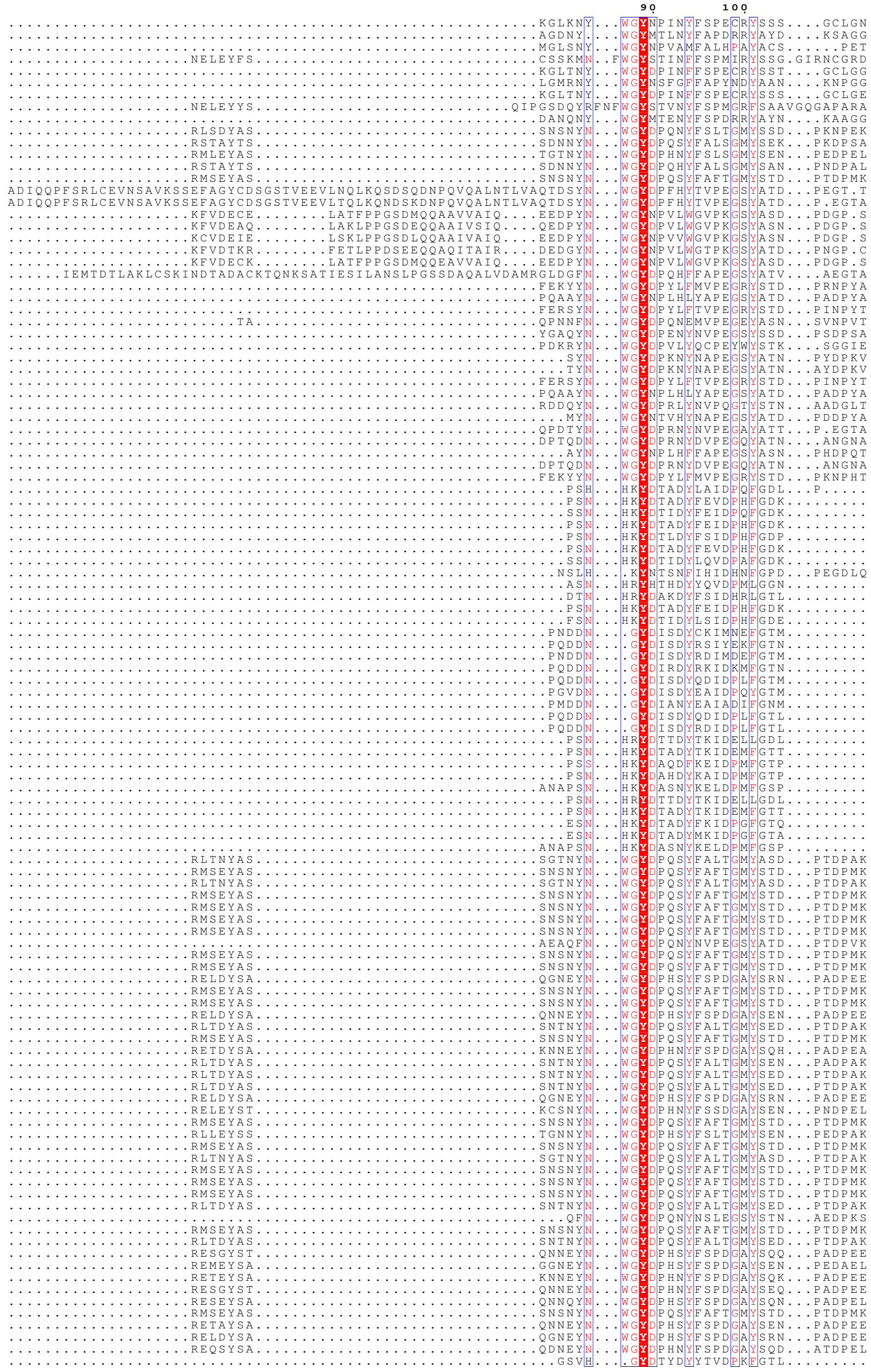



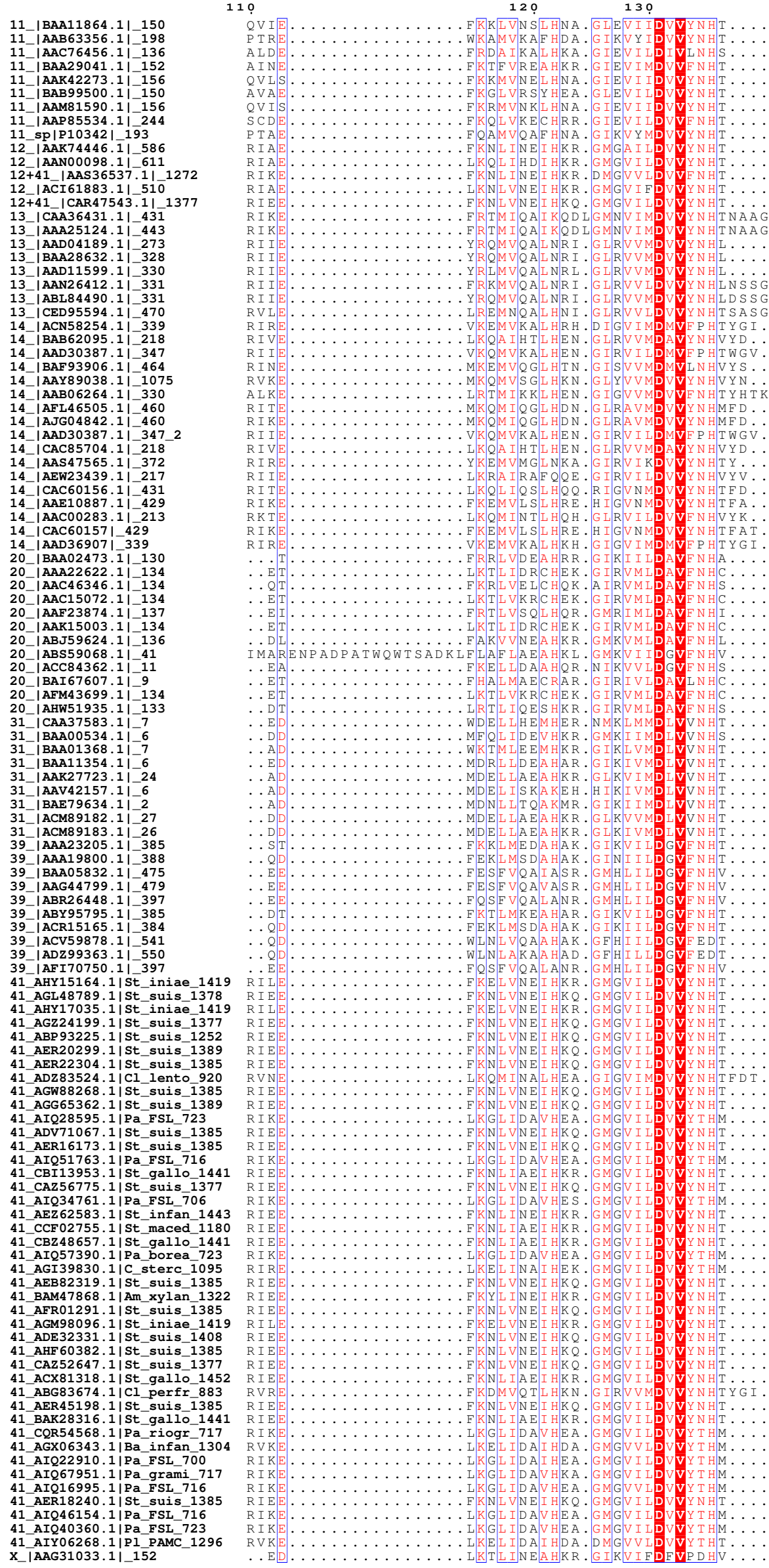

140

150

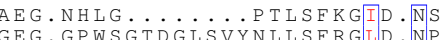

AEL.DLDG.........PLESLRGID. NR

AEG.NERLG $\ldots \ldots$ P TISERGID. NT

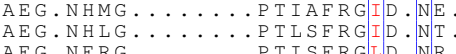

AEG.NERG . D X A P TISFRGID.NR

AEG.GTWT.SSDPTTATIYSWRG ID. NA

AKT.YLFE.

$A Q V$. HIFE

SKT.FLEE

TDRT SVLD.
TDRS

DSS.GPFG

YSS.GPFA

CGISSVLD

GVM.SPFD

QSA. SAFE
ASE. HAFN.

GKF. SIFD.

AKA.SNLD.

GVM. SPFD.

REQ. SPLE
TVGDSPED

TQI.SDFD

REN.SPEE

QI.SDFD

GDQFFAFR

GYEFAPF $Q$

GYEFPPFQ

GSASPQWQ.

GDQSMQWQ

SRGFFFFH

GDGHWAFA

GYEFAPFQ

SDE.HNWF.

SDE. HAWF

SDE. HAWF

SDQ. HKWF

SDE. HAWF
SDE.HAWF

SDD. SIYF

SDD.SI

SDD.SIYF

SDD. SIYF

SDD.SIYF.

GSD. SVYF.

SDD. SIYF

SKT. FLFE.

AKV.SIFE
SKT. FLFE

SKT.FLFE.

SKT.FLFE
SKT.FLFE

SKT. FLFE
DVT. SPFN

SKT. FLFE

AKK.ELLN

SKT.FLFE.

SKT. FLFE
$A K K$. DFLD

ADL. AILE
SKT. FLEE

AKK.EFLN.

ADL. A ILE

ADL. A I LE.

AKK.EFLN

SKT.FLFE.

ASV. HIFE

SKT. FLFE
AKV.SIFE.

SKT. FLFE.

SKT.FLFE
SKT.FLFE

SKT. FLFE

$A D L$. A I LE
GQN.SPED

SKT. FLFE.

ADL. A I LE
AKK. DFLD.

AKA.STLN.

.

AKK. EFLN

SKT. FLFE
AKK. DFLD

$A K K$. DFLD
$A K K$. EFLN

AQT. SLLD.

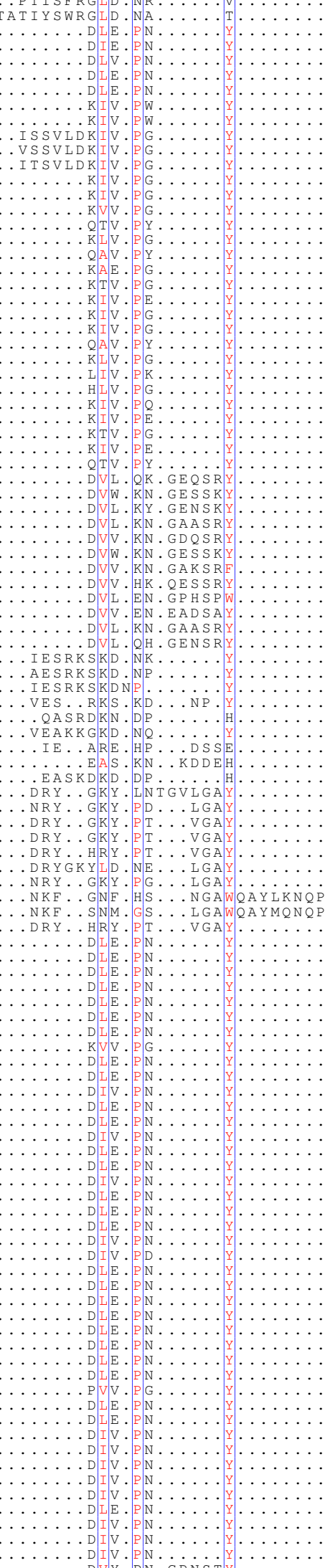


11_|BAA11864.11_150

11 AAC76456.1 198

|BAA29041.1 152

|AAK42273.11_-156

|BAB99500.11_150

|AAP 85534.1 1 - 244

sp |P10342| 193
$\mid$ AAK74446. 1 |_586

TAN $36537-1112$

+41_|AAS36537.1 | 127

12- IACI61883.11 510

13_ICAA36431.1 I_431

| AAA25124.1 $\left.1\right|_{-443}$

|AAD04189.11 _273

\begin{tabular}{l|l|l|}
\hline IAAD11599.1 & 330 \\
\hline &
\end{tabular}

|AAN2 6412.1| 1 - 331

CED

ACN58254.1 339

BAB 62095.11_218

|BAF93906.1|-464

AAB 06264.11330

|AFL 46505.11_460

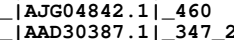

4_|AAD30387.1| 347 2 $^{2}$

4_|AAS47565.1|_ 372

ICAC60156.11 431

CAC60156.1 -431

AACO0283.1 429

4_ICAC $60157 i_{-429}^{4} 9$

|BAA02 243.1| 130
$\mid$ AAA22 622.1
| 134

|AAC4 6346.1|_134

|AAC15072.1| 134

AAK15003.1 134

Aak15003.11-134

ABS59068.1 131

ACC84362.1 11

|BAI67607.11_9

|AFM43699.1|_ 134

CAA37583.11_

_|BAA00534.1|_6

|BAA11354.1|-6

AAK27723.11-24

(1) 2

|ACM89183.1

AAA23205.11 385

AAA1 9800.1 - 388

|BAA05832.11_ 475

|AAG44799.11_479

|ABR26448.1|_397

ABY95795.1I_385

|ACR15165.11 38

ADZ99363.1 550

ADZ99363.1) 550

41_AHY15164.1|St_iniae_1419

41_AGL48789.1 | St_suis_1378

41_AHY17035.1 ISt_iniae_1419

_AGZ24199.1 |St_suis_1377

1_ABP93225.1 | St_suis_1252

41_AER22304.1 I St_suis_1385

1_ADZ83524.1 ICl_lento_920

1_AGW88268.1 ISt_suis_1385

-

11 ADV71067.1 ISt suis 1385

41_AER16173.1 | St suis 1385

41_AIQ51763.1|Pa_FSL_716

41_CBI13953.1 | St_gallo_1441

41_CAZ56775.1 | St_suis_1377

41_AIQ34761.1 |Pa_FSL_706

41_CCF02755.1|St_maced_1180

1_AIQ57390.1 1 Pa_borea_723

11 AFB82319.1 ISt suis_1385

41_BAM4 7868.1|Am_xylan_1322

41_AFR01291.1|St_suis_1385

41_ADE32331.1 | St_suis_1408
41_AHF60382.1 |St_suis_1385
41_CAZ52647.1 St_suis_1377

41_CAZ52647.1|St_suis_1377
41_ACX81318.1|St_gallo_1452

41_ACX81318.1|St_gallo_1452

1_ABG83674.1 C1_perfr_883

41_BAK28316.1 ISt_gallo_1441

1_CQR54568.1 | Pa_riogr_717

41_AGX22910.1 | Pa_FSL 700

41_AIO67951.1 Pa grami 717

41_AIQ16995. 1 |Pa_FSL 716

41_AER18240.1|St_suis_1385

41_AIQ4 6154.1 | Pa_FSL_716

41_AIQ40360.1 |Pa_FSL_723
41_AIY06268.1 | PI PAMC 129

41_AIY06268.1|P1_PAM

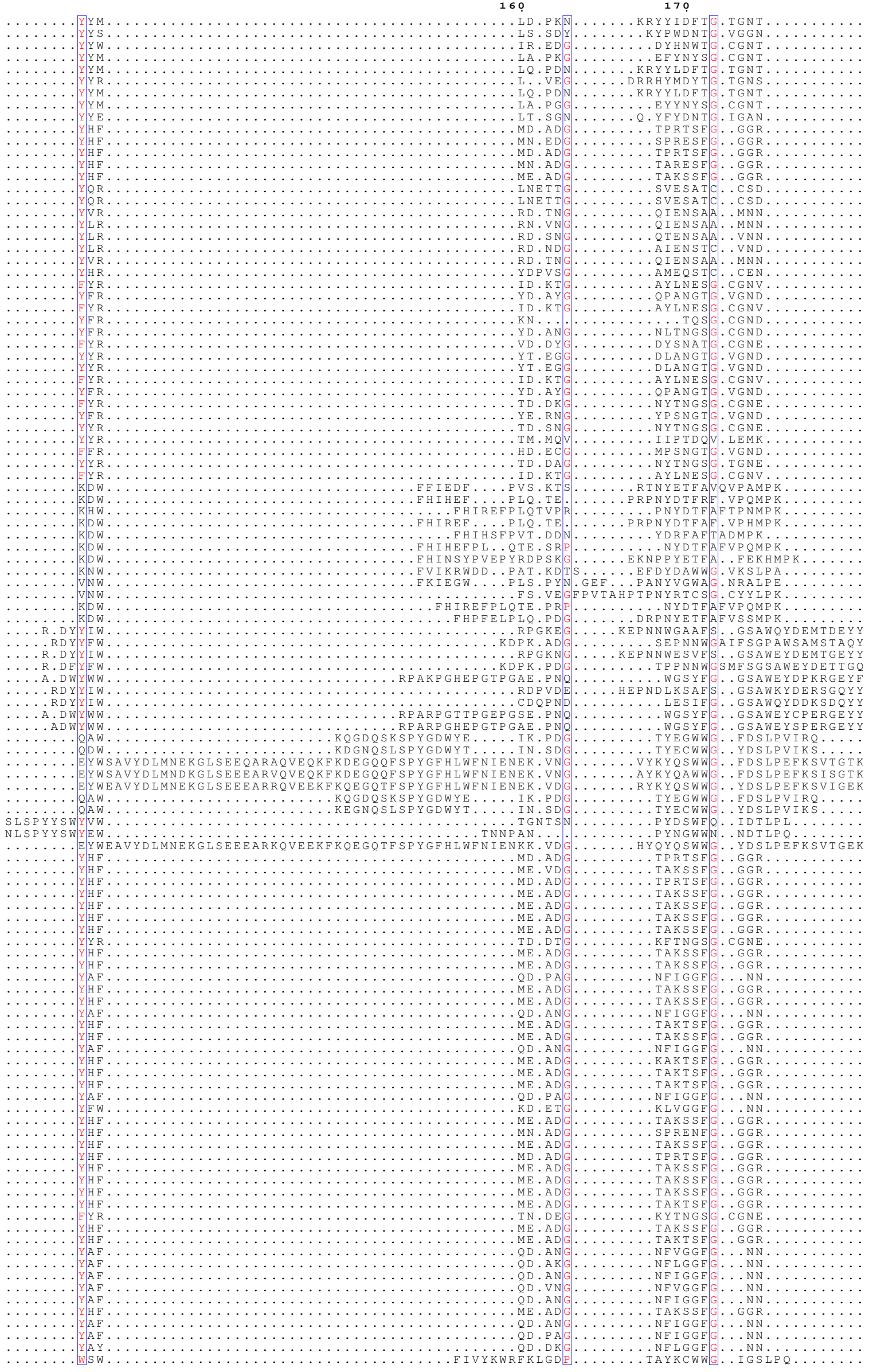


11_|BAA11864.1|_150

11 |AAC76456.11-136

11_|BAA29041.1| 152

11_|AAK 42273.1| 156

|BAB99500.1] 150

| AAM81590.1| 156

Sp|P10342|_193

|AAK74446.1 | 586

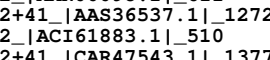

2+41_|CAR47543.1| 1377

3_|AAA25124.1| 443

| AAD 0 4189.1|_ 273

\begin{tabular}{|l|l|}
$\mid$ | AAD 11599.1 & 330 \\
$\mid$ AAN2 6412.1 & 331
\end{tabular}

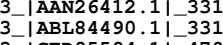

CED $95594.11-470$

ACN5254.11_339

BAB62095.1I_218

|BAF 93906.1 1 -464

|AAY89038.1|-1075

|AAB0 62 64.11 330

\begin{tabular}{|l|r|}
$\mid$ AFL 4 6505. 1 | 460 \\
\hline AJG0 4842.1
\end{tabular}

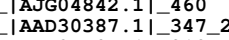

14_ICAC85704.1|_218

AAS47565.1 372

| CAC60156.1| 431

|AAE10887.11_429

4_ AAC00283.1 1 - 213

14_ICAC60157i $4 \overline{29}$

|BAA02473.11 130

|AAA22 622.11_-134

|AAC4 6346.1|_134

IAAC15072.1 1 - 134

AAAK15003.1I_134

|ABJ59624.1|_136

ABS59068.1 41

ACC 84362.1

0_ BAI67607.1|_9

|AFM43699.1 134

| BAA00534.1|-6

| BAA01368.1|_7

AAK27723.11-24

AAV79634.1 6

|ACM89182.1| 27

31_|ACM89183.1|_26

39_IAAA2 3205.1 - 385

39_| AAA1 $9800.1 \mid=388$

39-IBAA05832.1 -475

39_|AAG4 4799.1|_479

39_|ABY95795.1|_385

39-|ACR15165.11_384

AC $5878.1-541$

39-|ADZ99363.1|_550

41_AHY15164.1 ISt_iniae_1419

41_AGL48789.1|St_suis_1378

41_AHY17035.1|St_iniae_1419

41_AGZ24199.1 | St_suis_1377

41_ABP93225.1 | St_suis_1252

41_AER22304.1|St_suis_1385

41_ADZ83524.1|Cl_lento_920

41_AGW88268.1 ISt_suis_1385

11_AT6535.

41 ADV71067.1 St suis 1385

41_AER16173.1 ISt suis 1385

41_AIQ51763.1 | Pa_FSL_716

41_CBI13953.1|St_gallo_1441

41_CAZ56775.1 | St_suis_1377

41_AIQ34761.1 |Pa_FSL_706

41_AEZ62583.1 ISt_infan_1443

41 CBZ48657.1 ISt gallo 1441

41_AIQ57390.1 | Pa_borea_723

41_AFB2319.1 St suis 1385

41 BAM47868. 1 Am xylan 132

41_AFR01291.1 St suis 1385

41_AGM98096.1 |St_iniae 1419

41_ADE 32331 .1 | St_suis_1408

41_AHF 60382.1 | St_suis_1385

41_CAZ52647.1|St_suis_1377
41_ACX81318.1|St_gallo_1452

41_ACX81318.1 | St_gallo_1452

41_ABG83674.1 C1_perfr 883

41_BAK28316.1 | St_gallo_1441

41_AGX06343.1 | Ba_infan_130

41_AIQ22910. 1 | Pa_FSL_700

41_AIQ67951.1 | Pa_grami_717

41_AIQ16995. 1 |Pa_FSL_716

41_AER18240.1 | St_suis 138

41_AIQ46154.1|Pa_FSL_716

41_AIQ40360.1|Pa_FSL_723
41_AIY06268.1|PI_PAMC_1296

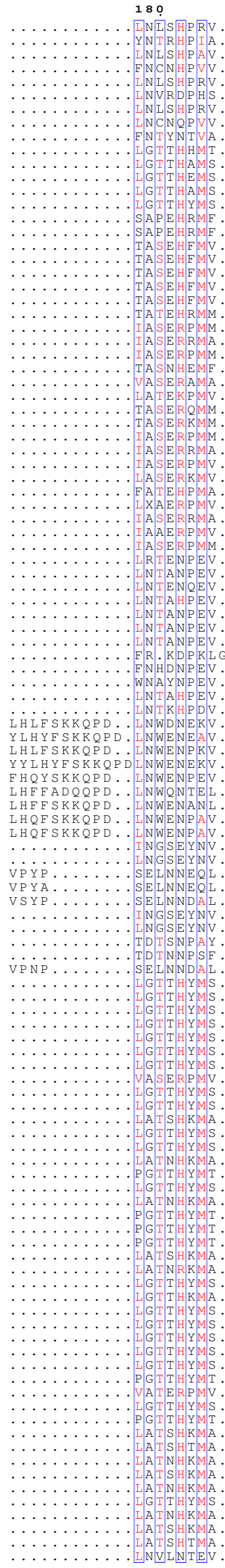

190

200

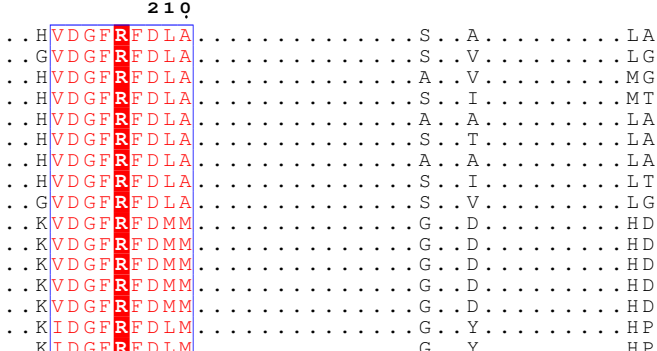

I MKR TMV

IM

IM

IM

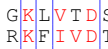

RRWIIVD

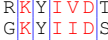

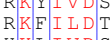

$H R L I V D$
$H R I T V D S$

RRYIVDI

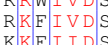

QREVIDS

RKEIID

QKFIIDS:

REYLTV

RAY

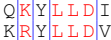

OPFILEI

PRDHVFEI

$\begin{array}{llll}R & \text { RH } \\ \text { RHH H L D D }\end{array}$

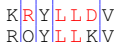

R Q D V Y EM M

RREVYDL
RRE VYYM

\begin{tabular}{l|l|l|l}
$R$ & $K$ & $E$ & $I$ \\
\hline
\end{tabular}

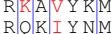

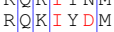

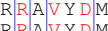

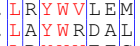

\begin{tabular}{lllll} 
L R R Y W V T T E & $M$ \\
I R Y Y W V T T E & $M$ \\
\hline & $R$ & $Y$
\end{tabular}

I R Y W V T T E M

\begin{tabular}{l|l} 
LA Y W A A T T \\
IKY Y LVD T Y
\end{tabular}

I K K Y I L T S S E

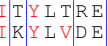

$\begin{array}{llll} & \\ \text { L A V V T T T } & D \\ \text { L L N W W A V N }\end{array}$

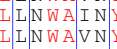

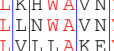

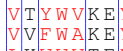

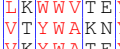

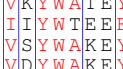

$\begin{array}{ll}V D D Y W & Y \text { NE } \\ \text { IKWWVVTE }\end{array}$

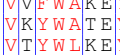

$\begin{array}{lll}V N Y W V V N & \\ \mathrm{Z} K Y Y W V N\end{array}$

VVV Y W L E E

\begin{tabular}{l|l}
$V T T$ & $Y$ W V V E E \\
AR R F W ME O
\end{tabular}

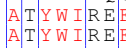

\begin{tabular}{l|l|l|l|l}
$A$ & $T$ & $Y$ & $W$ & R E E F \\
A & L & Y W I & $R$ & $R$ \\
\hline
\end{tabular}

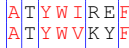

. ....

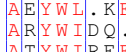

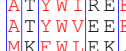

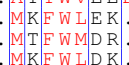

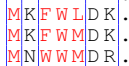

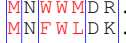

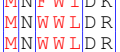

SWADF INNPNA ISKYWLNPDG D KNVGADG Wh

ANYI F Y E R D S V A K K S W T T R R.

作

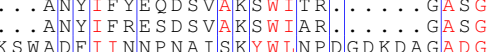

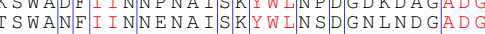

.

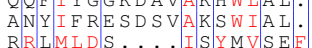

RRVLVD

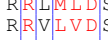

RRVIVDS

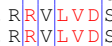

RKEIKDS

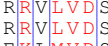

ERLMVD

R
RRVILV

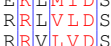

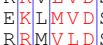

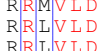

\begin{tabular}{llll}
$R$ & $R$ & $L$ & L V L L D \\
\hline
\end{tabular}

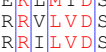

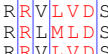

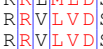

RRVIVDS

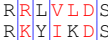

$\begin{array}{lll}R & R V I L V D \\ R & R & L\end{array}$ V L D S

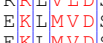

ERIMVDS

EKIMVDS

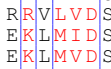

ERLMVD
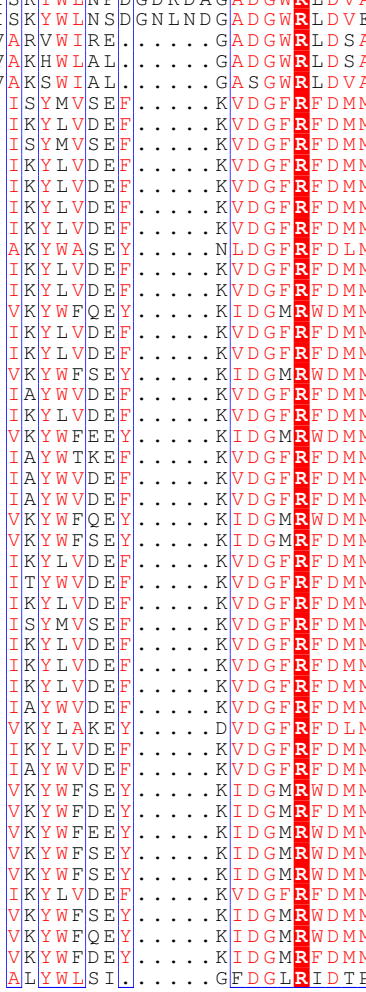

GADGW

KVDGF

$K V V D$
$K V D$

KVDGFREDMM $\ldots \ldots \ldots \ldots \ldots \ldots \ldots \ldots \ldots$

$K$
$K$$V D D$

$K I D D G M$
KVD GE

$\mathrm{K} I D G G$
$\mathrm{~K} V \mathrm{VDG}$
$\mathrm{KVDG}$

KID G

KVDGEREDMM

KVDGFE
KIDGMR
KIDGME

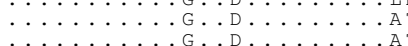

. . D . . . . . HD

G..D

$G: D$

$G$ G

$G \ldots D$

$G$ G

$G \ldots D$

$G \cdot D$

$G \cdots D$ 
11_|BAA11864.1| 150

11 AAC76456.136

11_|BAA29041.1 152

11_ AAK42273.1|-156

| AAM81590.1|_156

| AAP 85534.1 1 - 244

sp|P10342|_193

AAK 00098.11586

12+41_|AAS36537.1| 1272

12+41_ICAR4 7543.1 | 1377

13_ICAA36431.11| 431

3. IAAA25124.11-443

| AAD 04189.1| 273

| |BAA28632.1| 328

|AAN2 6412.1|_331

|ABL84490.1|_331

ACN58254.11 339

ACN254.1

AAD 30387.11

|BAF93906.1| 464

|AAY89038.1I 1075

| AAB 0 6264.11 330

\begin{tabular}{l}
$\mid$ AFL 4 6505.1 1 - 460 \\
\hline AJG04842.1 \\
\hline
\end{tabular}

_IAAD 30387.1 |-347_2

14_ICAC85704.1|_218

(4)

|CAC60156.1| 431

CAC60156.1 431

AAC $00283.1-429$

4_ICAC60157i_429

4_IAAD 36907|_339

_|BAA02473.1| 130

|AAA2 2622.1|_134

|AAC4 6346.1|_134

AAC15072.1I_134

AAF 3874.1137

AB 59624.1136

ABJ59024.1 136

ACC84362.1

BAI67607.1 9

AFM4 3699. 1 134

|AHW51935.1|_133

ICAA37583.1] 7

|BAA00534.11]

BAA01368.11

|BAA11354.11 6

AaV42157.11-6

BAE79634.1 2

ACM89182.11-27

|ACM89183.1| 2

AAA23205. 1 385

AAA1 9800.11388

|BAA05832.11_ 475

$\mid$ AAG44799.1|_479

|ABR2 6448.11_397

ABY 95795.1 _ 385

ACR15165.1| 384

ADZ99363.1) 550

|AFI70750.1| 397

41_AHY15164.1|St_iniae_1419

41_AGL48789.1 |St_suis_1378

41_AHY17035.1/St_iniae_1419

AGZ24199.1 St_suis 1377

1_ABP93225.1 | St_suis_1252

41_AER22304.1 | St_suis_1385

41_ADZ83524.1|Cl_lento_920

11_AGW8268.1 St_suis_1385

11. AI028595.1

41. ADV71067. I St suis 1385

41_AER16173.1|St suis 1385

41_AIQ51763.1|Pa_FSL 716

41_CBI13953.1 | St_gallo_1441

41_CAZ56775.1 | St_suis_1377

41_AIQ34761.1 |Pa_FSL_706

41_AEZ62583.1 | St_infan_1443

41 CBZ48657.1 ISt gallo 1441

11_AIQ57390.1 | Pa_borea_723

1_AGI39830.1 | C_sterc_1095

1_AEB82319.1 | St_suis_1385

1_BAM4 7868.1|Am_xylan_1322

1_AGM98096.1 St_suis_1385

1_ADE32331.1 |St suis 1408

41_AHF60382.1|St_suis_1385

41_CAZ52647.1|St_suis_1377

1_ACX81318.1 St_gallo_1452

1_ABG83674.1 C1_perfr_883

11_BAK28316.1 St_gallo_1441

1_CQR54568.1|Pa_riogr_717

1_AGX06343.1|Ba_infan_130

41_AIQ22910.1 Pa_FSL_700

41_AIQ67951.1 |Pa_grami_717

41_AIQ16995. 1 | Pa_FSL_716

41_AER18240.1 ISt_suis_138

41_AIQ4 6154.1|Pa_FSL_716

41_AIY0 0360.1 . Pa_FSL_723

41_AIY06268.1|P1

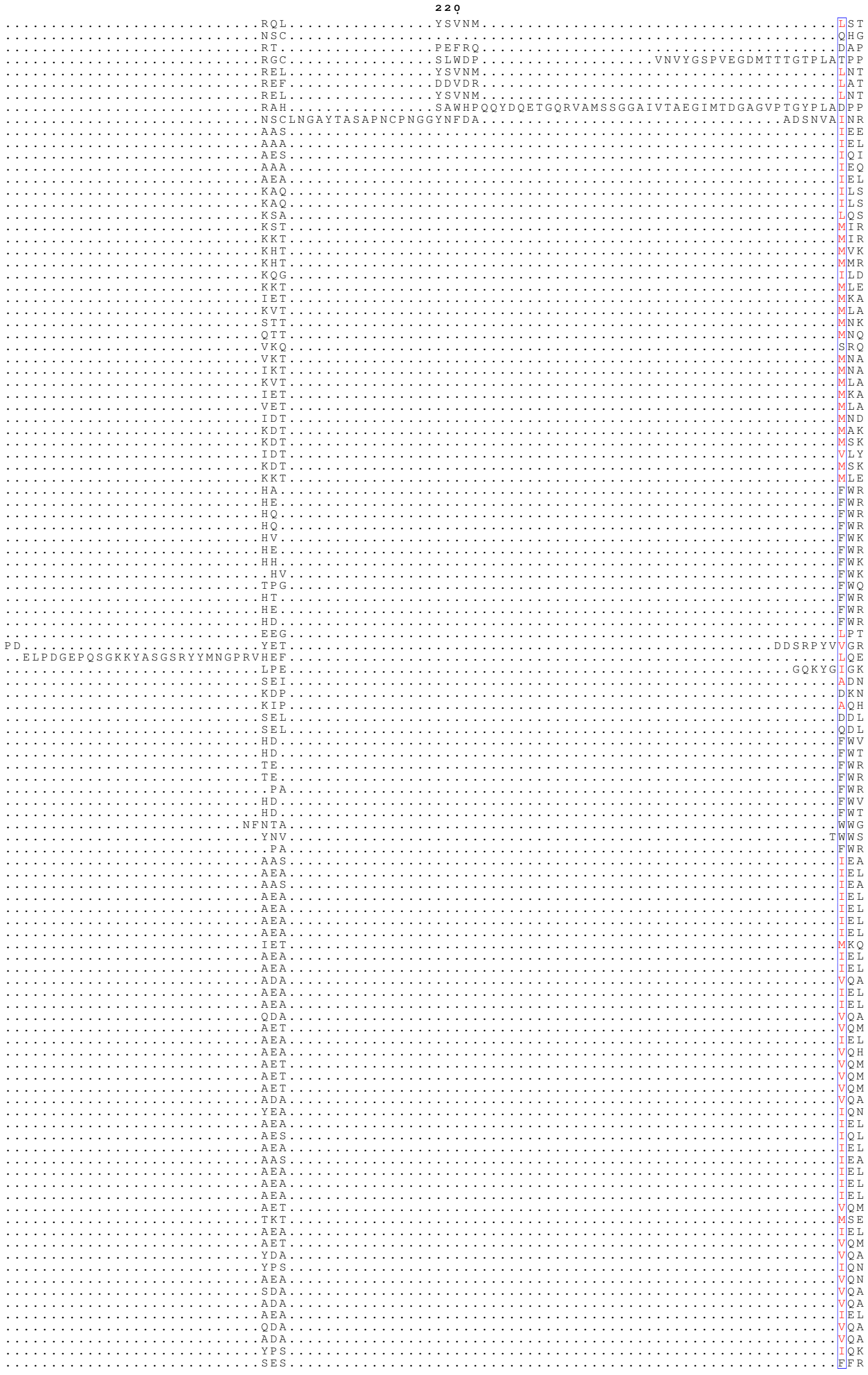



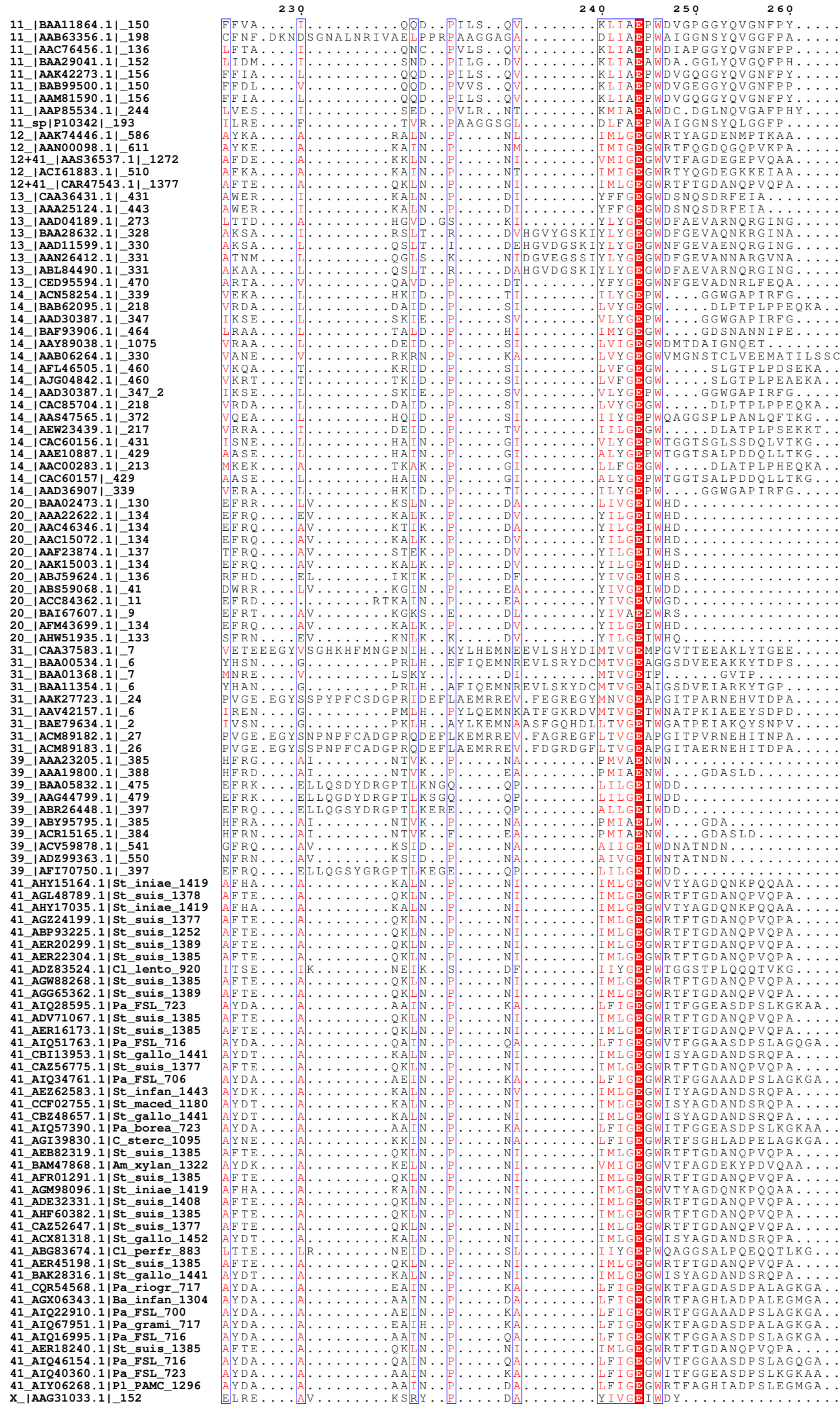

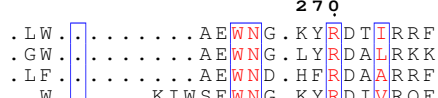
. AEWNG.KYDIVRQF TEWNG.KYRDTVRDE AEWNG.KYRDSIIRRE
SEWNG.KFRDVVRNE GGW QGW. . . . SEWNG. LFRDS IRQA DQDW.MKST. DTVGVESD.DIRNSIKSG DQQW.MQYT. EAVGSESD. EFRNEL YS

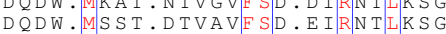
SQIN. IKGT. . GIGTESD.RLRDSVRGG SQIN.MSGT..GIGSEND.RIRDAING SQIN.MSGT.GIGSEND.RIRDSVNGG
SOLN.MSGT. . RIGSEND.RIRDAINGG

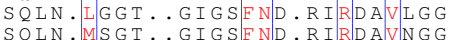
TQAN.MAGS..EVGGTED.RIREAVRGG

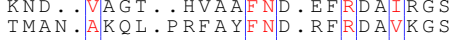
KAD.VGGT. GIAAEND. EFRDAIRGS TQPN. ASKV. KGVAFEND. SLRDAIKGS CQGY......SIGIEND. RIRDAIRGD

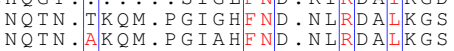

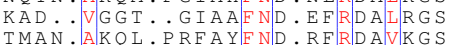
TMAN. AKQL.PRFAYFND.RFRDAVKGS
KORG . WTRIAVEND.HIRNAIKG.

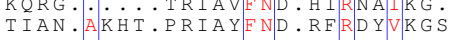
$\varrho Q K G . \cdots$. LGIGVEND.NIIRNGIDGN ALAN. APRM.PGIGFED. MERDAVKGN KSD..VAGT...HVAAFND.EFRDAIRGS ASGW. IMGD. Q ED SVMNY. LFRESVIRE AMPW. IRGD. QFDAVMNY. PFTDGVLRF

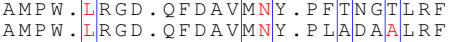
AMPW. IRGD. QFDA REAMNY. PFTEPMIEY AMPW. IRGD. QFDAVMNY. PFTDGVIRE

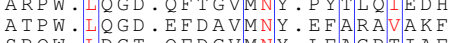
SRQW. IDGT. QFDGVMNY. LFAG PTIAE

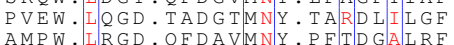

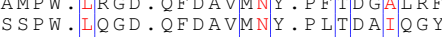
RKEL..... QMVFOFEHMD DDSGEGGK RHEL. IY...NMIFTFEHMDIDTKQHSP DRH. . . . ELNMIFNFEHMDVDTKPG

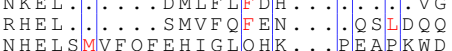

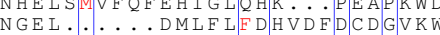
NGEL...... DMLEFEDHVDFDCDGVKW

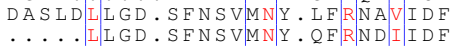
ASKY. FIGD. QYDSVMNY.RFRGAVIDF

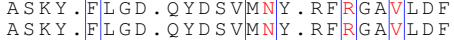
SLD . IILG. SENSVMNY. LFRNAVIDE GTDW. IIGGD.SFNSVMNY. QFERDIIIDF GTDW. ITGS.TFDSVMNY.SFRNAVIDE

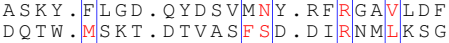
DQDW.MSST.DTVAVESD. DIRNTIKSG DQTW. MSKT. DTVASESD.DIRNMIKSG
DQDW. MSST.DTVAVESD.DIRNAIKSG DQDW. MSST. DTVAVESD. ETRNTIKSG
DODW MSST. DTVAVESD. ETRNTIKSG DQDW. MSST. DTVAVESD. EIRNTIKSG
DODW MSST.DTVAVESD. DIRNTIKSG SQKG....... DDFGEND. EIRGAIKGD DQDW. MSST. DTVAVESD.EIRNTIKSG DQKW.MDKT. DSVGVESD.EFRNEIKSG DQDW. MSST. DTVAVESD. EIRNTIKSG
DQDW.MSST.DTVAVESD.EIRNTIKSG DQQW.MDKT. DSVGVESD.EFRNEIKSG DQTW. MSQT. DSVASESD.DIRNLIKSG
DQDW MSST.DTVAVESDERTIKSG DQDW. MDKT.DSVGVESD. EFRNEIKSG
DOTW.MAT. DSVASESD. DIRNLIKSG DQTW. MAHT DSVASESD. DIRNLIKSG
DQTW.MSQT.DSVASESD. DIRNLIKSG DQTW.MSQT. DSVASESD. DIRNEIKSG DQKW.MDKT. DSVGVESD.EIRNEIKSG
DQDW.MDKT.DDVGVESD.EIRNEIKSG DQDW. MSST. DTVAVESD. ETRRTIKSG DQDW.MSST. DTVAVESD.ETRNTIKSG DQTW.MSKT. DTVASESD.DIRNMIKSG DQDW.MSST. DTVAVESD. EIRNTIKSG
DODW:MSST.DTVAVFSD.ETRNTIKSG DQDW.MSST.DTVAVESD.EIRNTIKSG

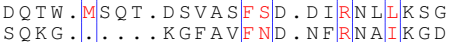

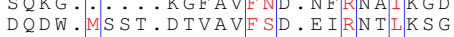
DQTW.MSOT. DSVASESD. DIRNLIKSG
DQAW:MDT.DSVGVESD.EFRNEIKSG DQDW.MDKT. DDVGVESD.EIRNEIKSG DQDW. MDKT. DNVGVESD. EFRNEIKSG

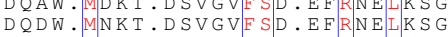
DQDW.MSST. DTVAVESD.EIRNTIKSG
DQOW.MDKT.DSVGVESDEFRNEKSG DQKW.MDKT. DSVGVESD.EFRNEIKSG

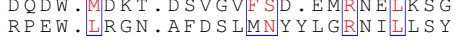


11_|BAA11864.1|_150

11 AAC76456.1 198

|BAA2 9041. 1 152

|AAK42273.11_-156

AAM81590.11_156

|AAP 85534.1 1 - 244

sp |P10342| 193
$\mid$ AAK74446. 1 |_586

AANO0098.1 -611 1272

1 +41_|AAS36537.11 1272

12_|ACI61883.1 I 5100

13_ICAA36431.11 - 431

| AAA25124.1 $\left.1\right|_{-443}$

|AAD04189.11 _273

| AAD 11599.1
I

|AAN2 6412.1
|ABL 84490.1
| 331

CED95594.11-470

ACN5254.1 339

BAB62095.1I_218

BAF 93906.1 1 -464

AAB0 6264.1 330

|AFL46505.11_460

|AJG0 4842.1| 460
|AAD 30387.1| $347 \quad 2$

14-|AAD30387.1| 347 I $^{2}$

4_ICAC85704.1|_218

AEW 23439.11217

CAC6156.1_431

(4)

4. ICAC60157i_429

|BAA02473.1| 130

|AAA2 2622.1|_134

AAC4 6346.1|_134

AAC15072.1| 134

AAK15003.1 134

AAR15003.1 - 134

ABJ59624.11-136

ACC84362.1 11

|BAI67607.1|_

|AFM4 3699.1|_-134

|CAA37583.11-7

| BAA00534.1|_6

| BAA11354.11_6

|AAV42157.11_6

|BAE79634.1|_2

|ACM8 9182.11_27

|AAA23205.1 $1{ }_{-385}^{26}$

AAA1 9800.1 - 388

|BAA05832.11_ 475

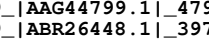

|ABY95795.1|_385

|ACR15165.1|_-384

|ADZ99363.1| 550

1 AHY15164. IISt iniae 1419

41_AGL 48789.1 ISt suis 1378

41 AHY17035.1 ISt iniae 1419

AGZ24199.1 St suis 1377

1_ABP93225.1 | St_suis_1252

41_AER22304.1 ISt_suis_1385

1_ADZ83524.1 |Cl_lento_920

1_AGW88268.1 I St_suis_1385

1.

11 ADV71067.1 ISt suis 1385

41_AER16173.1|St suis 1385

41_AIQ51763.1|Pa_FSL_716

41_CBI13953.1 | St_gallo_1441

41_CAZ56775.1 | St_suis _1377

41_AIQ34761.1|Pa_FSL_706

41_CCF02755.1 St_maced_118

41_CB248657.1/St_gallo_144

11_AIQ57390.1 | Pa_borea_723

1 AEB82319.1ISt suis 1385

41_BAM47868.1 |Am_xylan_1322

41_AFR01291.1 | St_suis_1385

1_ADE 32331 . St suis 1408

1_AHF60382.1|St_suis_1385

41_CAZ52647.1|St_suis_1377

1_ABG83674.1|C1_perfr_883

1_BAK28316.1 |St_gallo_1441

AGX06343.1 Ba infan 1304

41 AIQ22910.1 |Pa FSL 700

41_AIQ67951.1|Pa_grami 717

11_AIQ16995.1|Pa_FSL 716

1_AER18240.1 ISt_suis_1385

41_AIQ46154.1|Pa_FSL_716

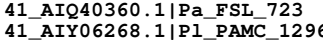

41_AIY06268.1|P1_P
280

RGD. . PVPY .

$\ldots$ NKLGV $\ldots$ DL
$\ldots$ DLGT

$$
\ldots \text { RGE . . . RATL }
$$

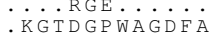

. NELGS. .MTIY
. PNEGQ. .PAFI

PNEGT . PAFI

. PNEGT. . AAFI

PFDSG. DALRQNQGIGSGAGVLPNELASLSDDQVRHLADLTRIG

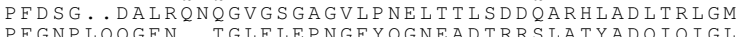

PFGNPIQQGEN..TGLFLEPNGFYQGNEADTRRS LATYADQIQIG .

PFGNPLQQGFS. TGLELEPNGFYQGNETETRLTLATYADHIQIGI.

PFGPPLQGYV. . TGLSLQPNDHDHSGKANADRMIAVAKDHIQVG. .AGNIKD.

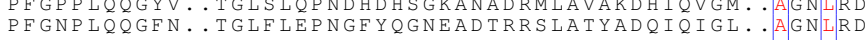

LFATESKDDYLRDQD

FHLPD...KGFA. MA

FNATV.. KGFL..MG .

SNNGGS̈̈GGFA. .

. FSDED. TGFI..AAG

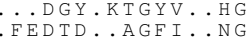

FEDTE..AGEV. .NG

. FNATV. . KGEL . M
FHLPD. RGEALGNP

DNDGT. IKGYV..QG

FDKTA. . QGFA. . TG.

FDSSA. . QGFA. Th .

. FHLKA. TIGFA. . LG

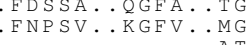

Aं $\dot{\mathrm{K}} \dot{\mathrm{E}}$

AQHEIRASQE

$\ldots \ldots \ldots$ A

A $\mathrm{AKEKI}$. . .

AGDRVVLEQVQ. . SR

AंKEEI $\ldots \ldots$ AD

SG GKWQMKP
S G . KWDI

. PAGKWALKPE.

DQEEKW

$$
\text { VRELL } .29
$$

ILDKSDDKPWTPADL

LIGQSFDDGN..GQH.

L...RRGK

ILDKQEDDGN ... V. VVH

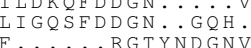

$\ldots$ RGTYNDGNV $\ldots$ QH

KNGN

GNEGE. . PAFL . T

PNEGQ..PAFI..TG

PNEGQ..PAAI . . T

PNEGQ

PNEG

.

PNEGQ

. GSEGD

. PNEGQ

PSEGA.

GSEGQ

PSEGA.

P SEGA

PSEGA

GHEGE

TEGQ. . PAF

. GSEGQ..PRFI.

. GNEGE. . PAFI

. PNEGQ. . PAFI.

PNEGQ

PNEGQ

. PSEGA

PNEGQ.PGE

PSEGA. . AAF

GSEGE.PPR

. GSEGQ..PREI

GSEGE. . PRF

PNEGQ. .PAF

GSEGE. . PREI

GSEGE . . PREI

ALAK.. ETGVKR .
TLRLSLAGNILNYVLKDENGNSAKGSSE

.

NLSD . .VGRLIKQ .

KAGL.. ETRRIIKR.

ALAK. ETGVIKR

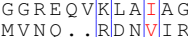

\begin{tabular}{l|l} 
MVNQ \\
DCSY
\end{tabular} KEAVII

DPNQ..VVDVIIKN

NGES.. ARAVMH

GYGK..ETKIIKR .

GEIH. . AERE DA.

GMMT

EDMS

QTI I

H KLD.

$\therefore$ KE $\mathrm{F}$ A N

.FDSILA.

gGid... ASAIAA.

SARQ..FADIMV

DAQV.

DP IA. I KKTMT

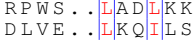

D L K P L D L G E L K K

etKL

NPिiD

NP

NPID

HAVD

GSR

GAKS

GSR S

GAKS

GAKS

GAKS

GAK

GARS

GAKS

GAKS

GAKD

GAKS

GARP

GAKD

GAKD

GARP

GAKS

GARN

GAKS

GAKS

GAKS

GAKS

ASGK

GAKD

GARD

GAR

GAKS

GARS

GAR

A SMR

290

300

RILGSPDLYAG

RFAaS SDVFKR.

CICGSPHLYQA.

$\begin{array}{ll}R & \text { I G S P D IY L G } \\ \text { RIT T GS S D LYAN }\end{array}$

TPHET DWWAN $\dot{G} \dot{G} \dot{Q} \dot{Q} \dot{K}$.

FF S S S SNLFQS

I

I KAQPHNF

\begin{tabular}{l|l} 
TI & $K A Q P$ P N N \\
$N$ & KA OP G NF \\
\hline
\end{tabular}

YNGAPGGY.

VILISHTGEAKKGSEIHTE

YVLRTHTGEAKKGSDIYTH

TISTGERKGSEIRTE

L IT

SWINSOPSAY

YDGKLI IKS

GVAGS IEYDEVIRS.

VILGCNNKREG I DENGHCN

IKAAID D F

IVGEIAYDKDIQG.

VIAGSIEYDEVIRS.

.

GIMGAID D F

VI G S I Q D F

I A GSSGWKALAP

GVEGSINDE.

.

EITRARMLY

QMMH V L H S

RIMHVLHSY

VNAHLMNG

H T D O L MMY.

.

AEYATKIIQEVLQ Q

G LNA LHAE I

\begin{tabular}{l|l} 
R L L H SY \\
A L T K K L M S Y
\end{tabular}

NIT KWQKA

RW Q TA...
TMT KWQKE

RWQYE

RMTEQQEA.

KWOTEL.

T MAgyota.

RIMS I YERY

RLMS IYERY

RITAVREDY.

. RITA IREDY...

RIMS IYERY.

R IMS I Y ERY

IMRLYSEY.

RITAIREDY

NIKAQP GN

NIKAQPTNE.

NIKAQPGNE

NIKAQPGNE.

\begin{tabular}{l|l}
$N$ & $K A Q P$ \\
G G G F
\end{tabular}

NIKAQPGNF 

1 _AAB63356.1|_198 1_|AAC76456.1 |_136 _|AAK42273.1|_156 |BAB99500.1|_150 | AAM81590.1|-156 |AAP 85534.11_244 sp|P10342| 193 AAAK74446.1 1 -586

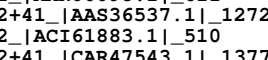
12+41-|CAR47543.1| 1377 3_|AAA25124.1| 443 | AAD 0 4189.1 | 273 AAD 11599.1| 130 AAN2 6412.1 331 |ABL84490.1|_331 ACN58254.11-339 IACN58254.11 339 (BAB62095.1I_218 BAF93906.1 34

AAY 89038.1 1075

|AAB06264.11_330

|AFL46505.11_460

|AJG04842.1| 460

|AAD 30387.1| $347 \_2$
|CAC85704.1|_218

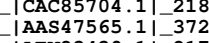

CAC60156.11 431

CAC60156.1_431

IAAC00283 1 - 213

ICAC60157i $4 \overline{2} 9$

|AAA2 2622.1|_134

|AAC4 6346.1|_134

|AAC15072.1| 134

AAK15003.1|_134

|ABJ59624.1|_136

|ABS59068.1|_41

|ACC84362.1| 1

BAI 67607.11 9

|AFM4 3699.1 134

BAA00534.11

|BAA01368.1|-7

BAA11354.11 6

|AAV42157.11_6

IACM89182.11-27

| ACM89183 1| 26

|AAA23205.11 385

|AAA1 $9800.1 \mid-388$

|BAA0 5832.1| 475

$\mid$ AAG4 4799.11 479
$\mid$ ABR26448.1 397

|ABR26448.1| 397

|ACR15165.1 1 - 384

ACV $5878.11-541$

ADZ99363.1 -550

41_AHY15164.1|St_iniae_1419

41_AGL48789.1 | St_suis_1378

41_AHY17035.1 |St_iniae_1419

41_AGZ24199.1 | St_suis_1377

41_ABP93225.1 | St_suis_1252

41_AER22304.1 |St_suis_1385

41_ADZ83524.1 |Cl_lento_920

41_AGW88268.1 | St_suis_1385

41 AIO28595 1 (Pa_

41 ADV71067.1 St suis 1385

41_AER16173.1 |St_suis_1385

41_AIQ51763.1|Pa_FSL_716

41_CBI13953.1 | St_gallo_1441

41_CAZ56775.1 I St_suis_1377

41_AIQ34761.1 |Pa_FSL_706

41_CCF02755.1 I St_maced_1180

41_CB248657.1|St_gallo_144

41_AIQ57390.1 Pa_borea-723

41 AEB82319.1 ISt suis 1385

41_BAM4 7868.1|Am_xylan_1322

41_AFR01291.1 It_suis_1385

41_AGM98096.1|St_iniae_1419

41_ADE 32331.1 |St_suis_1408

41_CAZ52647.1 St_suis_1377

41_ACX81318.1 | St_gallo_1452

41_ABG83674.1 |Cl_perfr_883

41_BAK28316.1 | St_gallo_1441

41_AGX06343.1 | Ba_infan_1304

41_AIQ22910. 1 | Pa_FSL_700

41_AIQ67951.1 | Pa_grami_717

41_AIQ16995.1 |Pa_FSL_716

41_AER18240.1 ISt_suis 138

41_AIQ46154.1|Pa_FSL_716

41_AIQ40360.1 Pa_FSL_723
41_AIY06268.1|PI_PAMC_1296

X |AAG31033.1| 152

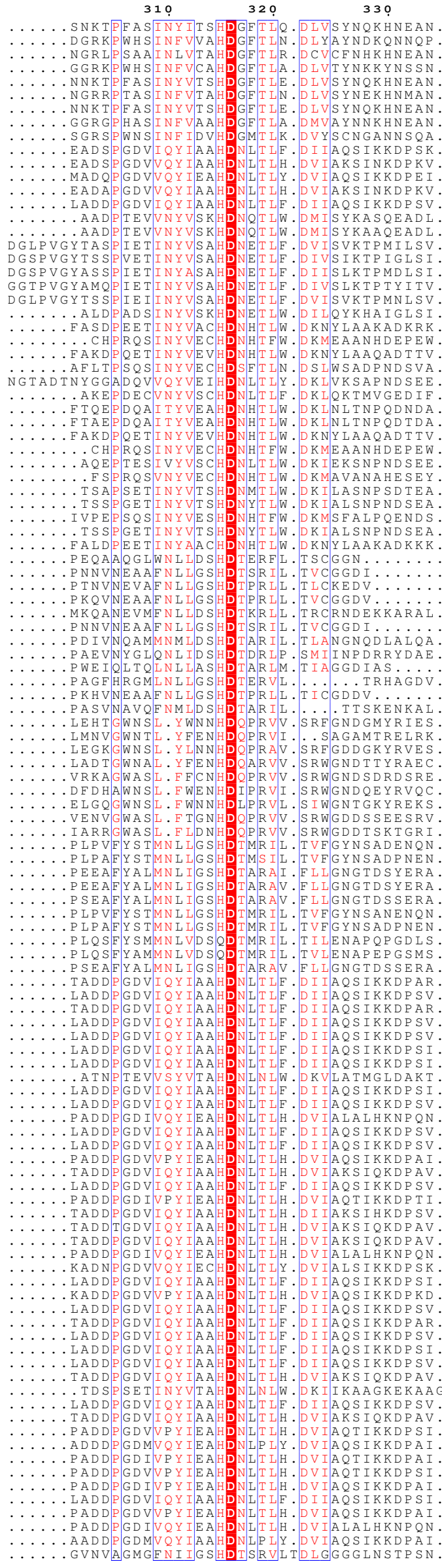

340

350

360

370

D GNENYS WN C GVEGE T N D S I L Y CREK ORRNFV

. .....GGIVAEQRKAART GI

GEDNRDGENHNLSWNCGEEGEFAGLSVKRLRKRQMRNFF

GFNNQDGMNENYSWNCGAEGP TNDQNVVICREKQKRNFM

. GEDGRDGESHNRSWNCGVEGP TDDPEIMQLRAQQRRNFL

GFNNQDGMNENYSWNCG TEGT TNDQNVIMCREKQKRNFM

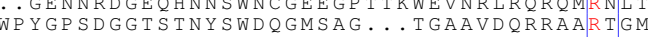

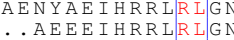

AENDLEIHKRIRVGN

TENYTEIHOROR LGN

ATRVRMQAVSI

DTRVRMQAVSI
DERCRINHIAS

DEKCRINHLAS

DERCRINHLS I

DERCRVNHLAT

ENRVRVQNMAA

KWTEEELKNAQKLSG

KWTEEMLKDAQKLAG

THQARVTLAN

TILARAKLAD
WIDRATIAN

TKTKMHRLAS

K

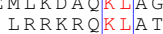

DRIRMNLLAN

DR I KMDELA IA

DR I KMDELAH

RKRSRQRLAV

EWTEERLKNDQ

EAKFRLAV

RKVKLLE

RKAKL S F
RKVIK LL L F

$\dot{R} \mathrm{~K} \dot{\mathrm{K}} \dot{\mathrm{L}} \mathrm{L} \mathrm{L}$

NSPR W N PNYDVRKPTAEEIRRQKI I

EAALL SY
RKAKLLE

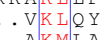

QSRQSISIA

A R AFA

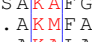

RSAKALC
RSAKALA

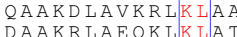

ELDPNYNE QLGKQRSKVAV

ELDPNYNEQLGKKRLKLAA

LDPNYNEELGKKRLKLAA

SQEAKDLAVKRLKLAA

ALQQDEYRPSPAAEQLGIERLKLVS

ALOOATYOPTATDOOLGIKRLELVS

ELDPNYNEELGKKRLKLAV

AENYTEIHORORIGN

AENYAEIHRRLRLGN

AENYTEIHQRQRLGN

TENYTE I HQRQR L GN

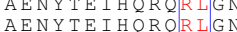
PYASITGNVLENEAVKRSILAN AENYTEIHQRQRLGN . TENYTEIHORORIGN PANELEIQQRIRLGN AENEAEIQRRLRLGN TENYTEIHQRQRLGN TENELEIQKRIRLGN AENEAEILRRQRLGN AENEAEIQRRLRLGN AENEAEIQRRLR GN AGNLLEIOKRIRLGN . HAEETHORTRIGN TENYTEIHQROR LGN AENYAEIHRRLRLGN TENYTEIHQRQRLGN AENYTEIHQRQRLGN TENYTEIHQRQRLGN AENEAEIQRRLRLGN ENYTEIHQRQRLGN A ENEAEI QRRLRLGN PENNLEIHKRIRLGN EKNELEI OKRIR LGN PANELEIOKRIRLGN PGNELEIQKRIRLGN AENYTEIHQRQRLGN PANELEIQQRIRIGN PANELEIOKRIRLGN ES I ARLKLLS 


11 |BAA11864.11 150

11-|BAA11864.1] 150

1_|AAC76456.1|-136

|BAA2 29041.1|-152

|BAB99500.11-150

IAAM81590.11- 156

Sp|P10342i_193

AAAK74446.11_586

+41_|AAS36537.1I_1272

2. IACI61883.1 1 . $510^{127}$

3. ICAA36431.1 431

3.|AAA25124.1 $1-443$

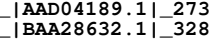

$\mid$ IAAD11599.1
$\mid-330$
AAN26412.1 331

|ABL84490.1| 331

CED 5954.11731

(1)

BAB62095.1 218

| IAAF 93906.1|-464

AAAY89038.11-1075

AAB06264.1 -330

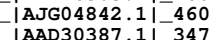

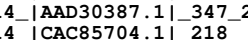

| CAC85704.1| 218

A.

(1) 431

(a)

ICAC60157| 429

BAA02473.1] 130

IAAA22622.1] 134

AAC46346.1 _-134

AAAC15072.1 134

AAK15003.1_ 134

AAK5003.1-134

ABS59068.1

ACC 84362.1

|BAI67607.11 9

$\mid$ AFM43699.1|-134
$\mid$ AHW51935.1|_ 133

|CAA37583.11-7

_|BAA00534.1|_6

|BAA11354.11 6

AAV42157.1 6

AAV79634.1 6

|ACM89182.1|_27

1_ IACM89183.1|_26

|AAA23205.1| 385

|AAA1 9800.1 - 388

\begin{tabular}{l} 
IBAA0 5832.1|r 475 \\
\hline
\end{tabular}

|ABR2 6448.1|_397

ABY95795.1I_385

|ACR15165.1| 384

|ADZ99363.1| 550

AHY15164.1 I St iniae 1419

11_AGL48789.1 ISt suis 1378

11 AHY17035.1 | St iniae 141

11 AGZ24199.1 St suis 1377

41_ABP93225.1 | St_suis_1252

41_AER22304.1 I St_suis_1385

ADZ83524.1 |Cl_lento_920

1_AGW88268.1 ISt_suis_1385

1 AI 28595.1

41_ADV71067.1 ISt suis 1385

41_AER16173.1 ISt suis 1385

41_AIQ51763.1 Pa_FSL 716

41_CBI13953.1 ist_gal1o_1441

41_CAZ56775.1 ISt_suis_1377

41_AIQ34761.1 |Pa_FSL_706

41_CCF 02755.1|St_maced_1180

41_CB248657.1|St_gallo_144

1_AIQ57390.1 | Pa_borea_723

41_AEB82319.1 | St_suis_1385

41_BAM47868.1|Am_xylan_1322

41_AFR01291.1 | St_suis_1385

41_ADE 32331.1 St suis 1408

41_AHF 60382.1 ISt_suis_1385

41_CAZ52647.1 ISt_suis_1377
41_ACX81318.1 It gallo_1452

41_ACX81318.1 |St_gallo_1452

41_ABR45198.1 St suis 1385

41_BAK28316.1 ist_gallo_1441

AGX6343.11 Ba infan 1304

41 AIQ22910.1 Pa FSL 700

41_AI067951.1|Pa_grami 717

41_AIQ16995.1 |Pa_FSL 716

41_AER18240.1 | St_suis_1385

41_AIQ4 6154.1 |Pa_FSL_716

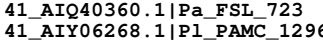

41_AIY0 6268.1|PI PAM

410

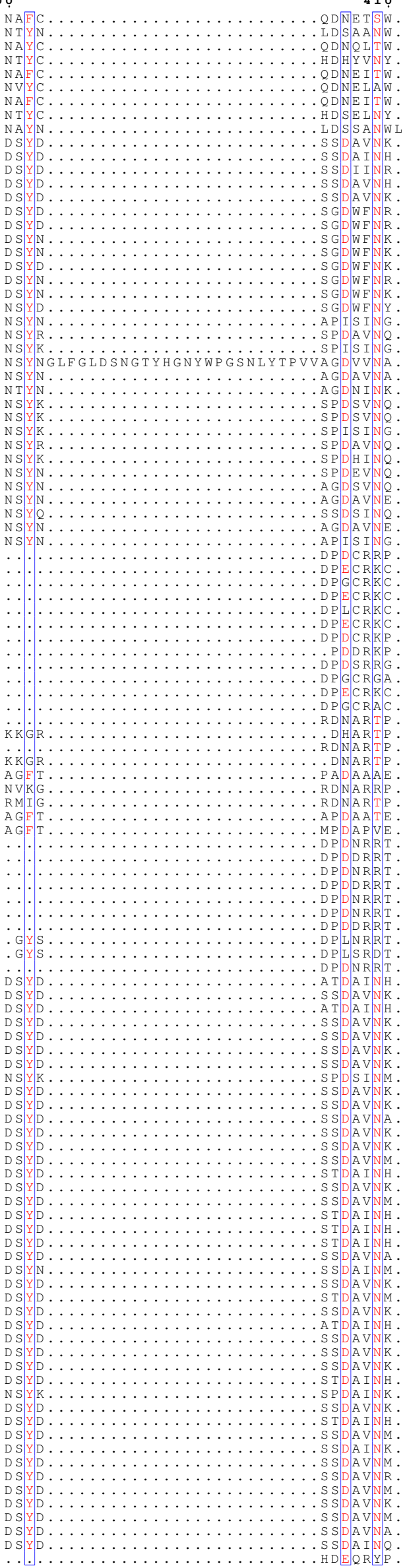

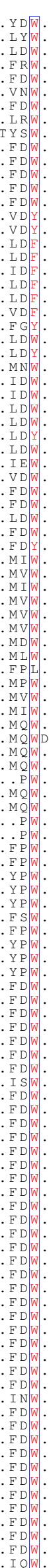

420

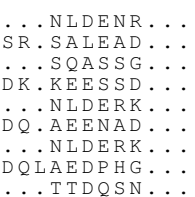

VRFHDFVRR

\begin{tabular}{ll|l} 
HET Y T KR \\
LTAFTA TAA
\end{tabular} LQRECS L

SKF LEFVKK
. . LVSFTRR

SKFLEFVKK

FNRFVRI

$\ldots$ TTDQSN A. . FYTFAQR

AA. ATDNNKHPISTKTQAYTAG

EK.ATDAEKYPVNNVTRDYTAG

AK. ATDSIAHPISNQTKAYTQG S L QDNNYN V.

S L QDNNYN

TYETNN.

TYETNN
TYETNN

SYNSNN

YETNN

... TYNTNN

ER.KSRYED

AR. KAEFID

SLKEKFED

KR. KMDRQQ

KL. KMDRQA

AR. KAEFID

S RKYTY..... DVRYYYG RKHTYYEE..... . F LYHQG

SR.KAQFKD . ...VVFDY Y FS

DR.RETFKE .... DVHYIRR

. . . SRKAQYPD ...VVFNYYSC

$\ldots$ EEKEQN ...RELEEFYKE

DPMQQNKELHQHVKQLIA LRKQ
DEHQONRELFRHVQK DPEKQNKELYEHVKQLIALRKQ

DPMQQNKELHQHVKQLIALRKQ
.

GK........................

EDLSYEDEV S CPVPNCNRPADK. NVFNRD . . . L LFDFYRK EA. NWNQEIFNTHRQLITIRQT NEESWNTRLLDGIRTFAA RAH DEEKQNKELYEHVKQLIALRRQ
DE.AKQDKD.......MLAFLTQ

DD QNHA G F T T GEP W I T VNPNYKEINVKQAI QNKDS I FYYYKK

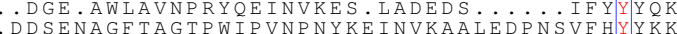
DGSFNAGFTTGTPWLKVNSRYSE. INVAKALQEPDSIFYYYYS NDENA DASONAGESTADKTWLPVNPNYKDINVOAALKNSNSIEYTYO ISVNPNHAEINAAGEFDDPDSVYAFYKK IAVNPNHTEINAADETDDPDSVYSTHKR

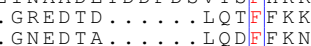
GSEDKE....... . LIAHYQK GSEDTE ..... I IAHYQK GKEDQN $\ldots \ldots$ LLSHYQK
. GREDKD. . . LODFFKK GREDKD $\ldots \ldots$ LQDEFKK
. GNEDTT $\ldots \ldots$ LQDFFKN GNEDT T $\ldots \ldots$ LQDFFKN
DNQNLD $\ldots \ldots$ LLNHYRK
. GHENEA $\ldots \ldots$ LLNHYRI

GHENEA SK. ATDSKVFPESTKSOAYMKG TK. ATDEALYPENTRTQAFTKG SK. ATDSKVFPESTKSQAYMKG TK. ATDETLYPENTRTQAFTKG TK. ATDEALYPENTRTQAFTKG TK. ATDETLYPENTRTQAFTKG . ATDEALYPENTRTQAFTKG
. ANRNSY...KEVTEYYEG

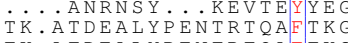
. A AK. ATDEALYPENTRTOAFTKG TK. ATDEALYPENTRTQAFTKG TK. ATDEALYPENTRTOAFTKG TK. ATDESQFPVQNTTRKYTSG AK. ATDGKVYPENAKTQAYTKG
AK.ATDSEAYPENTQSOAYTKG AK. ATDSETYPENTQSQAYTKG AA. ATDEVNFPVQNATREYTAG TK. A TDEALYPENTRTQAFTKG TK. ATDEALYPENTRTOAFTKG SK. ATDSKVFPESTKSQAYMKG TK.ATDEALYPENTRTQAFTKG TK.ATDEALYPENTRTQAFTKG AK. ATDSEAYPENTQSQAYTKG . QNKEKF.... AFT K K AK. ATDSETYPENTQSQAYTKG
AK. ATDEVNYPVONTTRAYT QK. ATNASAYKVNTMTREYT TK. ATDESOEPVONTTRRYTSG SK.VTDEVNFPVQNMTKDYTSG TK. ATDEALYPENTRTQAFTKG . VTDEVNYPVQNITKDYTAG A . ATDEVNFSVNATREYTAG QK.ATNKKEFAVNNTTRA TEG 
11_|BAA11864.1| 150

11 |AAC76456.1| 198

11_ BAA29041.11-136

11_|AAK42273.1|_156

_IBAB99500.1|_150

1_-|AAM81590.1|-156

_sp|P10342 I_193

|AAK74446.1| 586

+41 |AAS36537.11 1272

2+41-IAAS36537.1 I-127

12 -41_I CAR47543.1 I-1377

13_ICAA36431.11 I 431

13_|AAA25124.1|_443

13-|AAD04189.1| 273

13-|BAA28632.1|_328

13_|AAD11599.1|_330

13_|ABL84490.1|_331

13. CED $5594.1 \mid 470$

4_ ACN58254.1।_339

14- BAB 62095.1|_218

14_| BAF93906.1 | 464

14_| AAY89038.1| - 1075

14_|AAB0 6264.1| 330

14_|AFL46505.1|_460

14_|AAD 30387.1|_347_2

14_ICAC85704.1|_218

14-|AAS 4 7565.1| 372

14_ICAC60156.1 |_431

14_|AAE10887.1|_429

14_|AACO0283. 1 - 213

14_ICAC60157i_429

20 |BAA02473. 1 | 130

20_|AAA22 622.1|_ 134

20_|AAC4 6346.1|_134

20-|AAC15072.1|_134

20_|AAK15003.1|_134

_ AAB59624.1|_136

_|ABS59068.1I_41

0_|ACC84362.1|_11

0_|BAI67607.11_9

|AFM43699.1 1 - 134

|CAA37583.1 7

31_IBAA00534.1|

31_ | BAA01368.1| 7

31_|BAA11354.11_6

作

BAE79634.1 2

31-|ACM89182.1|-27

31_|ACM89183.1| 26

39_|AAA2 3205.1 1 | 385

39_|BAA05832.1|_475

39_|AAG4 4799.1|_479

39_|ABR2 6448.1|_397

9_|ABY95795.11_385

39-IACR15165.1|-384

9-|ACV59878.1|_541

39-|ADZ99363.1| 550

41_AHY15164.1|St_iniae 1419

41 AGL 48789. 1 | St suis 1378

41_AHY17035.1|St iniae 141

41_AGZ24199.1 St suis 1377

41_ABP93225.1 | St_suis_1252

41_AER22304.1|St_suis_1385

41_ADZ83524.1|Cl_lento_920

41_AGW

11. ATO28595.1 P

41_ADV71067. 1 ISt suis 1385

41_AER16173.1|St suis 1385

41 AIO51763.1|Pa FSL 716

41_CBI13953.1 i St_gallo_1441

41_CAZ56775.1 ISt_suis_1377

41_AIQ34761.1 |Pa_FSL_706

41_AEZ62583.1 | St_infan_1443

41 CBZ48657.1 ISt_gallo_1441

41_AIQ57390.1 |Pa_borea_723

41_AGI39830.1 |C_sterc_1095

1_AEB82319.1 |St_suis_1385

41_BAM4 7868.1 |Am_xylan_1322

41_AFR01291.1 St_suis_1385

41_ADE 32331.1 |St suis 1408

41_AHF60382.1|St_suis_1385

41_CAZ52647.1| St_suis_1377

41_ACX81318.1 St_gallo_1452

41_ABG83674.1 C1_perfr_883

41_BAK28316.1 |St_gallo_1441

41_CQR54568.1 | Pa_riogr_717

41_AGX06343.1 | Ba_infan_130

41_AIQ22910.1 Pa_FSL_700

41_AI067951.1|Pa grami 717

41_AIQ16995. 1 |Pa_FSL_716

41_AER18240.1 |St_suis_1385

41_AIQ46154.1|Pa_FSL_716

41_AIQ40360.1
41_AIY06268.FSL_723
PI_PAMC 1296

41_AIY06268.1 P1

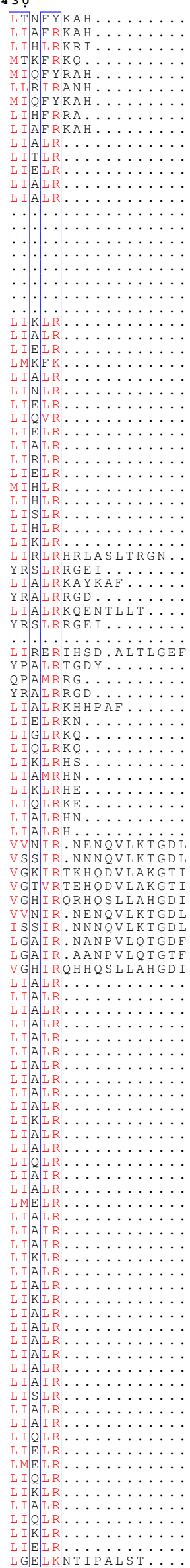




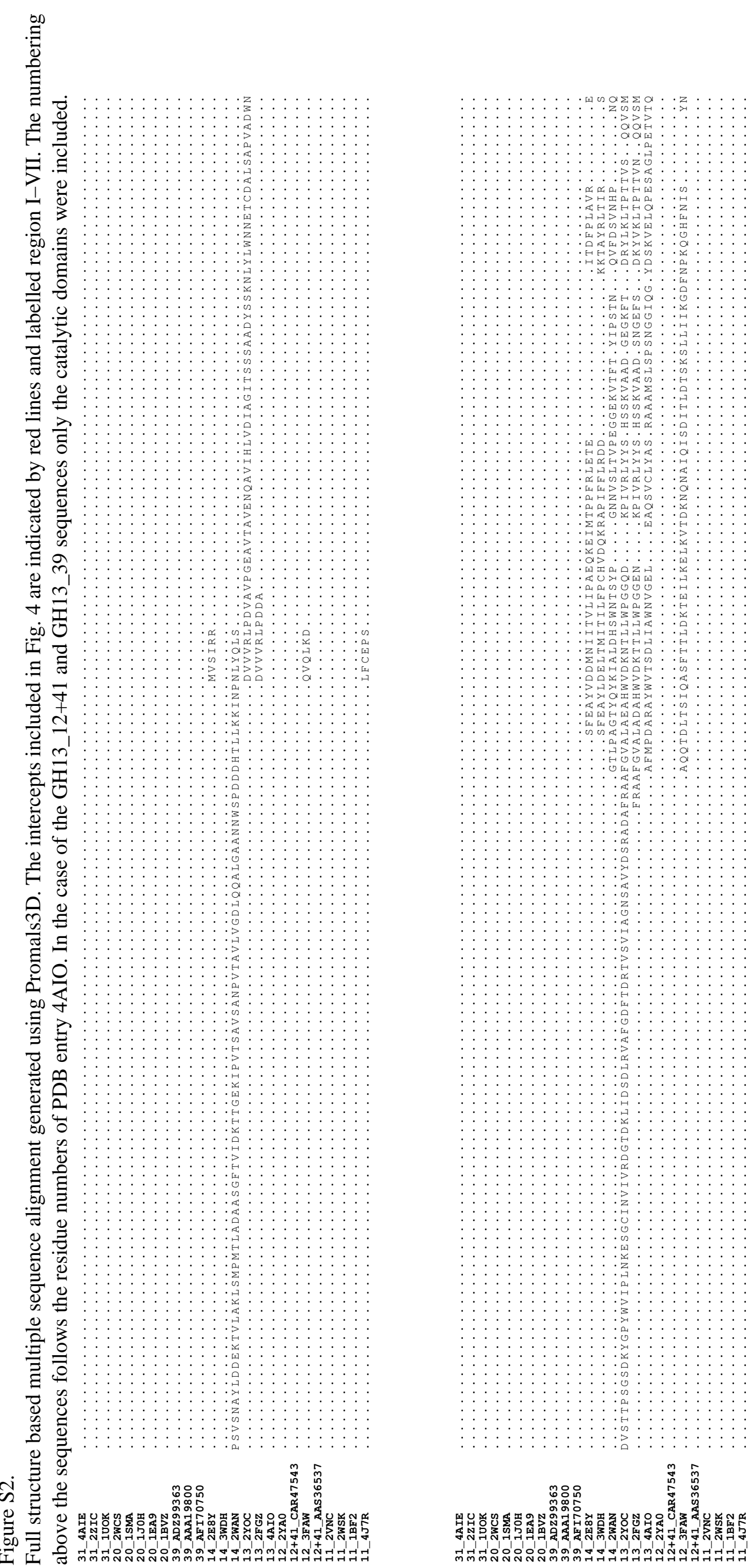



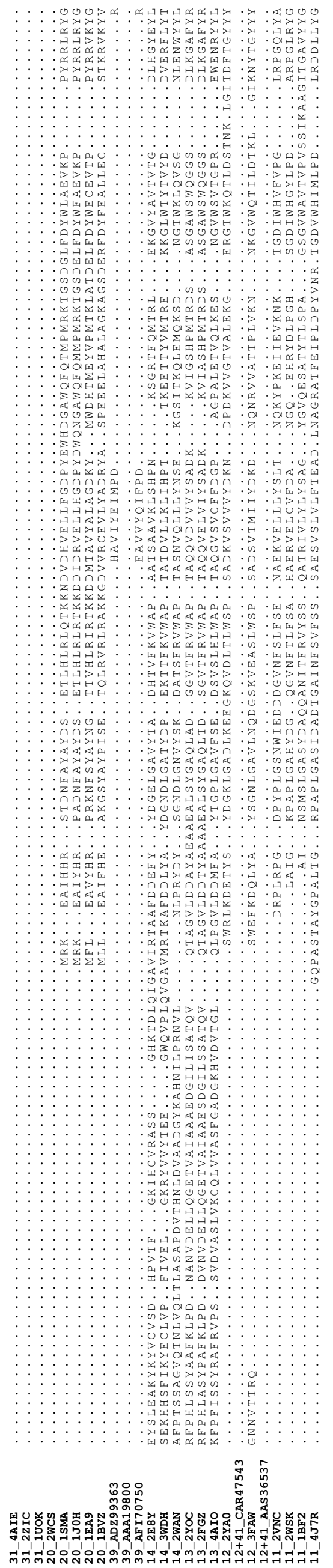
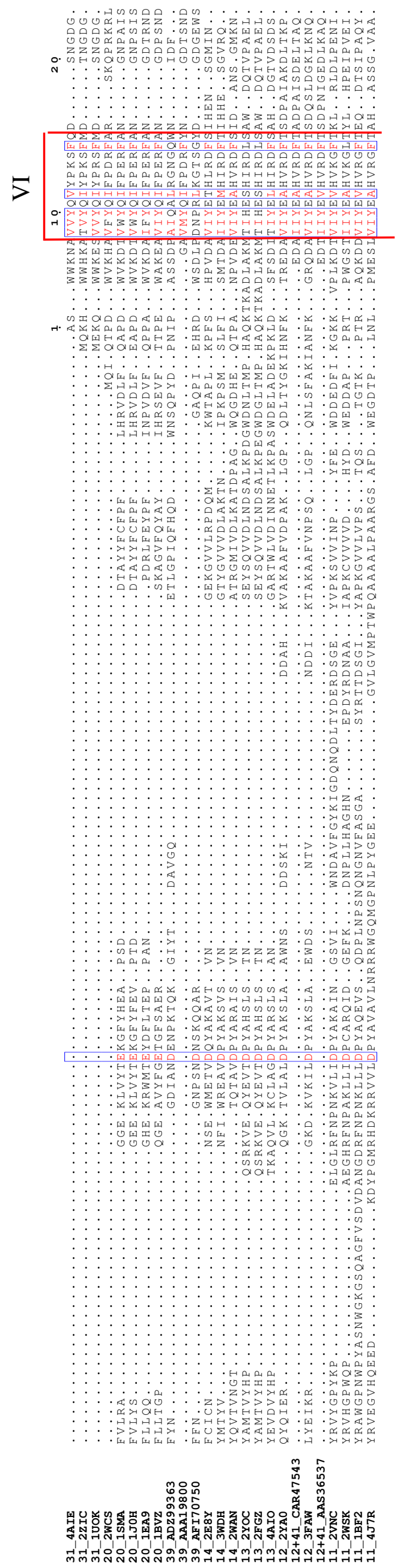


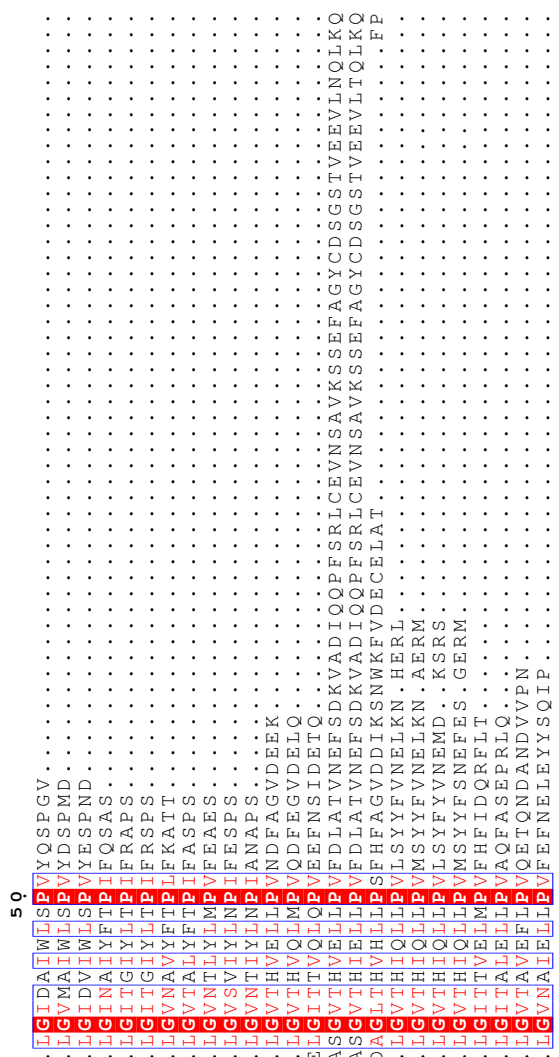

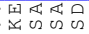

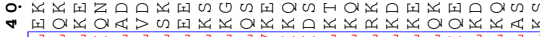

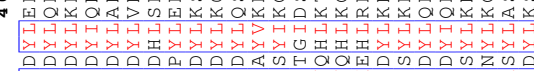

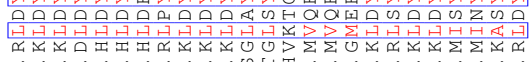

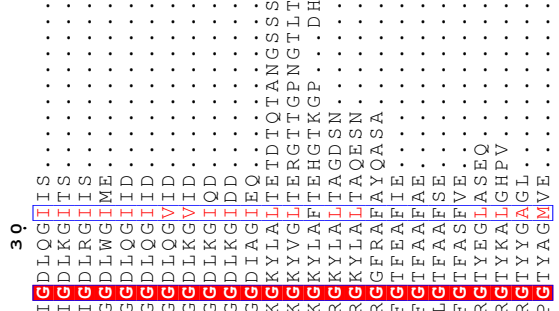

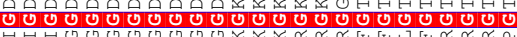
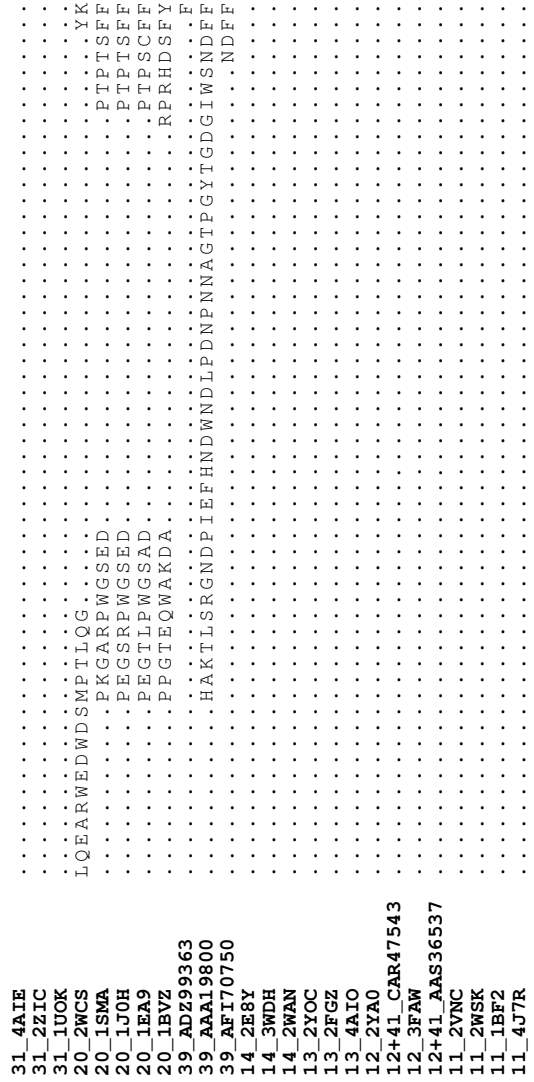
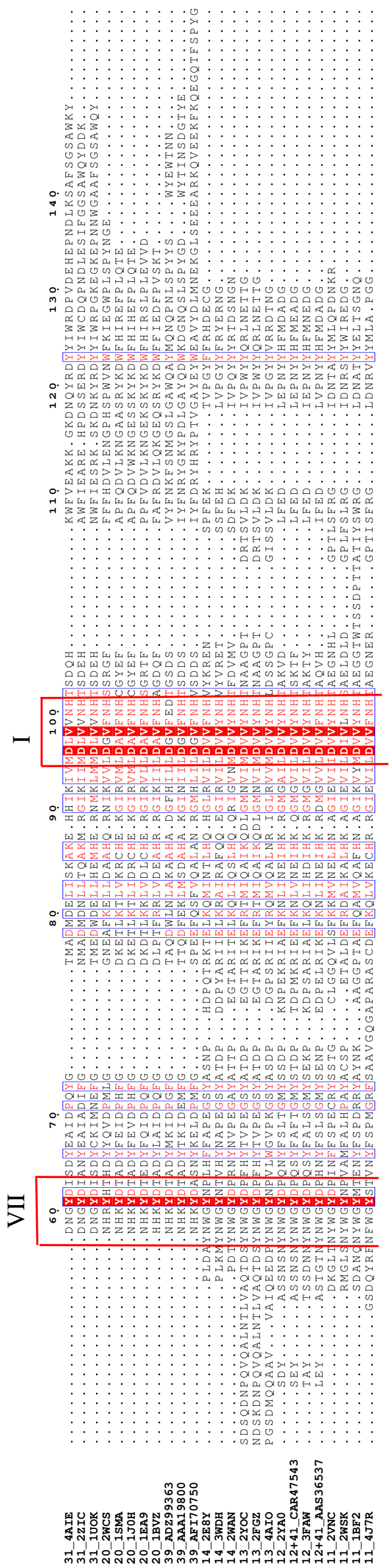

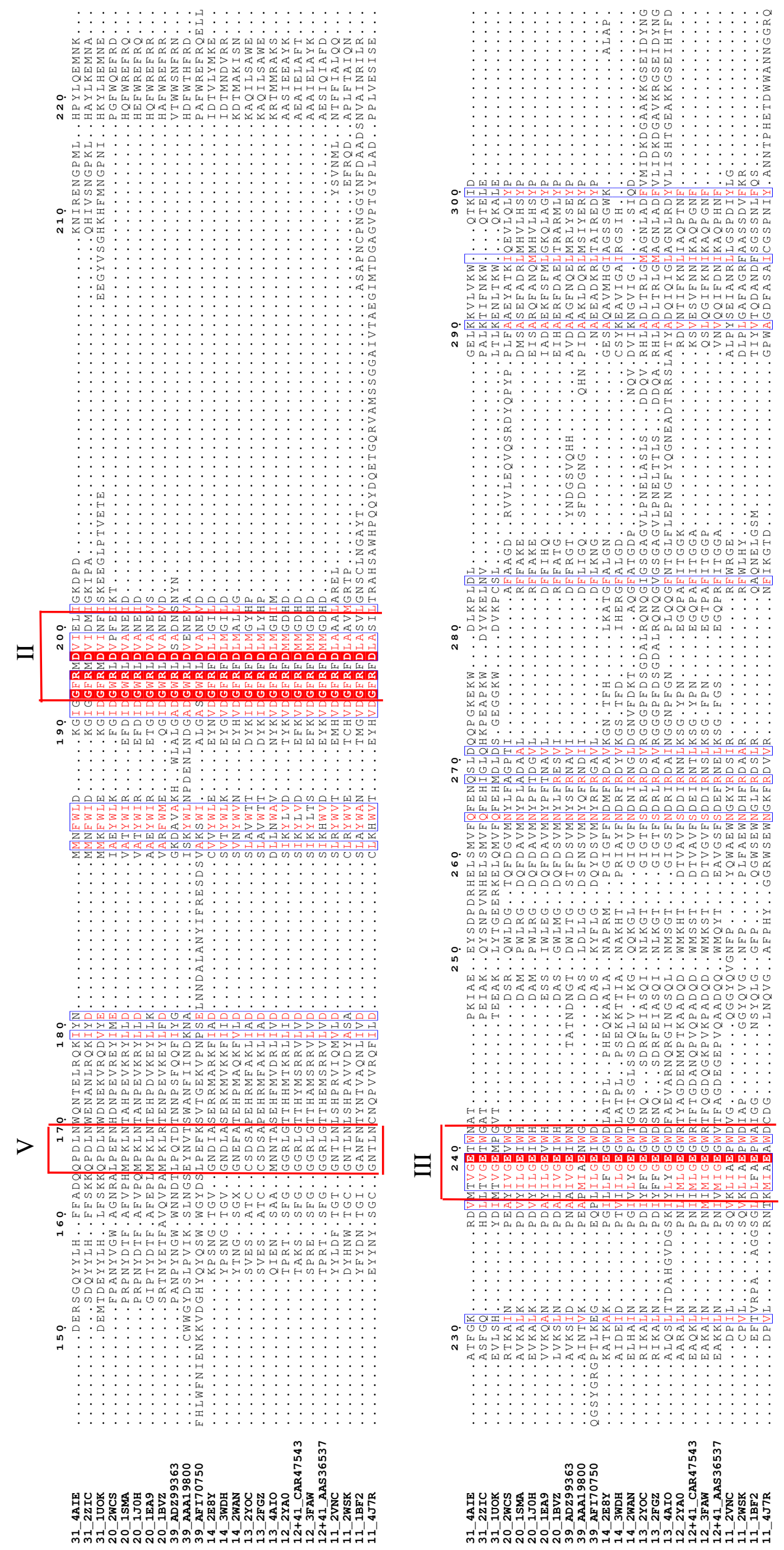

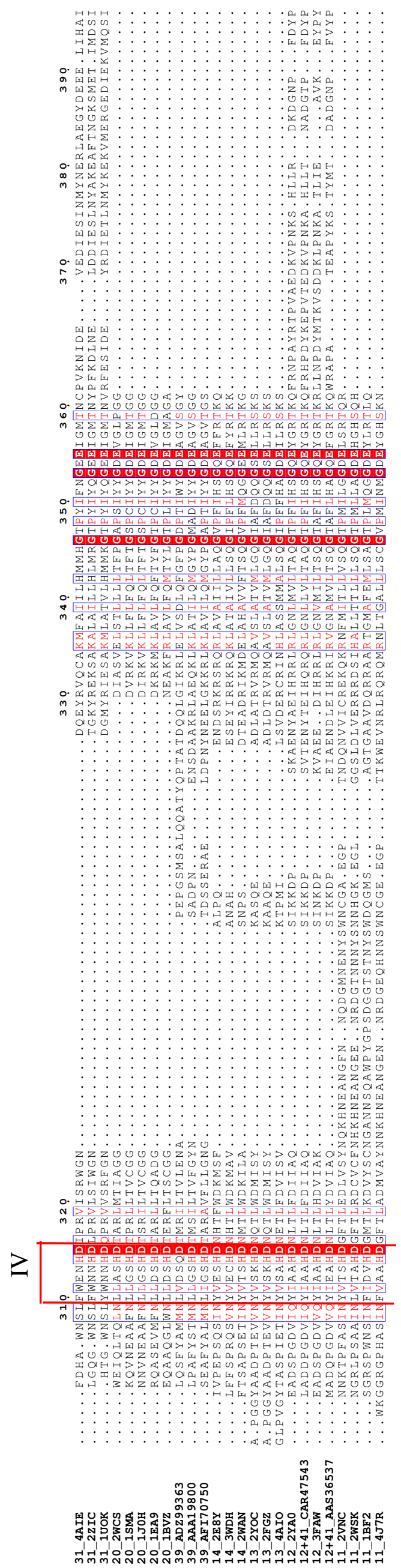

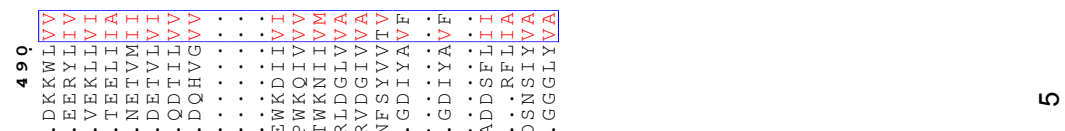

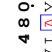

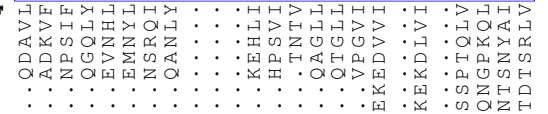
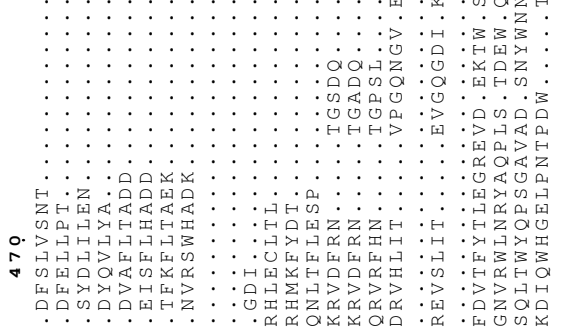

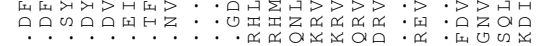

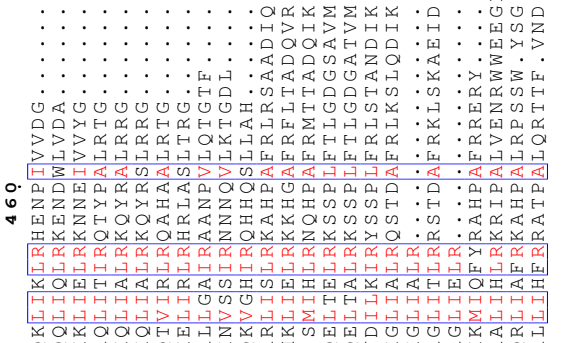
-

in

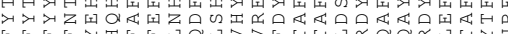

분부의

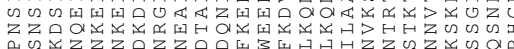

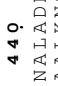

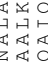

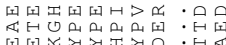

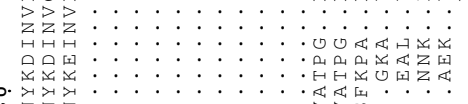

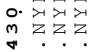

:

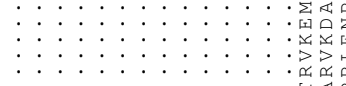

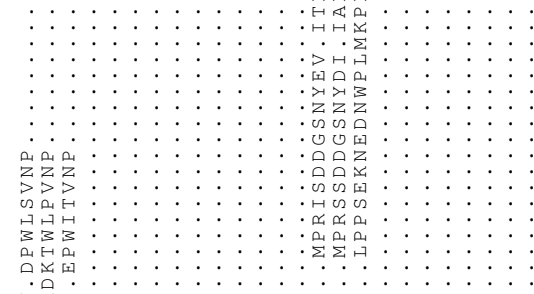

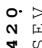

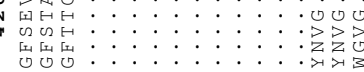

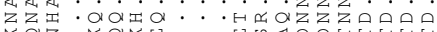

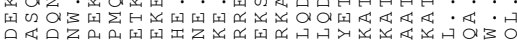

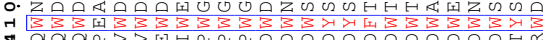

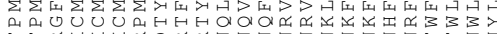

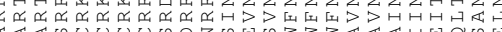

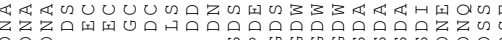

azzazas

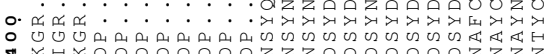

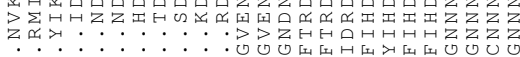

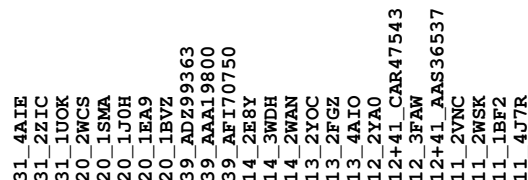




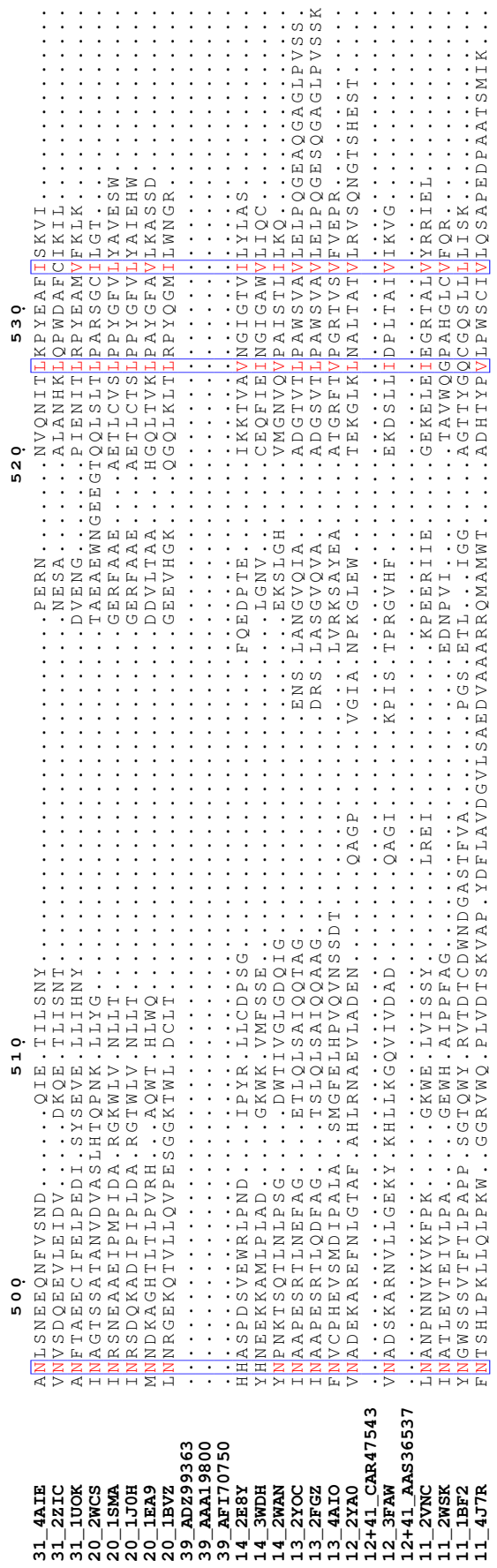


Table S1. Overview of the kinetic constants of members of GH13 subfamilies 11-14, and 39, and GH57 members with $\alpha$-glucan debranching activity. GH13 proteins, which experimentally have been shown to have $\alpha$-glucan debranching activity, but which are not included in a subfamily are included.

\begin{tabular}{|c|c|c|c|c|c|c|}
\hline \multicolumn{7}{|l|}{ GH13_11 } \\
\hline Source, enzyme type, GenBank accession no. & Substrate and assay conditions & $\overline{K_{M}}$ & $\boldsymbol{k}_{\text {cat }}$ & $V_{\max }$ & $\boldsymbol{k}_{\mathrm{cat}} / K_{\mathrm{M}}$ & Reference \\
\hline \multirow{5}{*}{$\begin{array}{l}\text { Escherichia coli str. K-12 substr. MG1655, GDE, } \\
\text { AAC } 76456\end{array}$} & $\mathrm{pH} 7.0,37^{\circ} \mathrm{C}$ & & & & & \multirow[t]{5}{*}[1]{} \\
\hline & Maltosyl- $\beta-C D$ & ND & ND & & ND & \\
\hline & Maltotriosyl- $\beta-C D$ & $1.51 \pm 0.14$ & $38.0 \pm 0$ & & $26.0 \pm 2.5$ & \\
\hline & Maltotetrasyl- $\beta-\mathrm{CD}$ & $0.15 \pm 0.03$ & $41.7 \pm 2.9$ & & $300 \pm 45$ & \\
\hline & Maltopentasyl- $\beta-C D$ & ND & ND & & ND & \\
\hline \multirow{4}{*}{ Sulfolobus shibatae B12, GDE, AAM81590 } & $\mathrm{pH} 5.5,70^{\circ} \mathrm{C}$ & $\mathrm{mM}$ & & & & \multirow[t]{4}{*}[2]{} \\
\hline & Maltopentaose & 246.3 & & & & \\
\hline & Maltosyl- $\beta-C D$ & 12.2 & & & & \\
\hline & Pullulan & 19 & & & & \\
\hline \multirow{6}{*}{ Sulfolobus solfataricus $\mathrm{P} 2$, GDE, AAK42273 } & $\mathrm{pH} 5.5,70^{\circ} \mathrm{C}$ & $\mathrm{mg} / \mathrm{ml}$ & $1 / \mathrm{s}$ & & $\mathrm{ml} /(\mathrm{mg} \mathrm{s})$ & \multirow[t]{4}{*}{ [3] } \\
\hline & Amylopectin & $\begin{array}{r}31.1 \pm 0.23 \\
(88.0 \pm 5.63)^{\mathrm{a}}\end{array}$ & $\begin{array}{r}0.923 \pm 0.006 \\
(17.35 \pm 0.96)^{\mathrm{a}}\end{array}$ & & $\begin{array}{r}(29.6 \pm 0.294) \cdot 10^{-3} \\
\left((197 \pm 16.7) \cdot 10^{-3}\right)^{\mathrm{a}}\end{array}$ & \\
\hline & $\mathrm{pH} 6.5,70^{\circ} \mathrm{C}$ & $\mathrm{mg} / \mathrm{ml}$ & $1 / \mathrm{s}$ & & $\mathrm{ml} /(\mathrm{mg} \mathrm{s})$ & \\
\hline & Amylopectin & $\begin{array}{r}92.3 \pm 7.41 \\
(345 \pm 28.3)^{\mathrm{a}}\end{array}$ & $\begin{array}{r}0.48 \pm 0.05 \\
(7.57 \pm 0.23)^{\mathrm{a}}\end{array}$ & & $\begin{array}{r}(5.21 \pm 0.654) \cdot 10^{-3} \\
\left((21.9 \pm 1.92) \cdot 10^{-3}\right)^{\mathrm{a}}\end{array}$ & \\
\hline & $\mathrm{pH} 5.5,70^{\circ} \mathrm{C}$ & $\mathrm{mM}$ & $1 / \mathrm{s}$ & & $1 /(\mathrm{mM} \mathrm{s})$ & \multirow[t]{2}{*}{ [4] } \\
\hline & Maltotetrasyl- $\beta-\mathrm{CD}$ & $0.206 \pm 0.003$ & $2570 \pm 334$ & & $1242 \pm 162$ & \\
\hline \multicolumn{7}{|l|}{ GH13_12 } \\
\hline Source, enzyme type, GenBank accession no. & Substrate and assay conditions & $\overline{K_{M}}$ & $\boldsymbol{k}_{\mathrm{cat}}$ & $V_{\max }$ & $\boldsymbol{k}_{\mathrm{cat}} / \boldsymbol{K}_{\mathrm{M}}$ & Reference \\
\hline \multirow{3}{*}{ Bacillus sp. KSM-1378, PULII_II, AAS36537 } & $\mathrm{pH} 9.0,50^{\circ} \mathrm{C}$ & $\mathrm{mg} / \mathrm{ml}$ & & $\mu \mathrm{g} / \mathrm{ml} / \mathrm{min}$ & & \multirow[t]{3}{*}{ [5] } \\
\hline & Pullulan & 0.72 & & 169 & & \\
\hline & Amylose & 0.27 & & 51 & & \\
\hline \multirow{2}{*}{ Streptococcus pneumoniae, PULI, SpuA, AAK74446 } & $25^{\circ} \mathrm{C}$ & $\mathrm{mM}$ & $1 / \mathrm{s}$ & & & \multirow[t]{2}{*}[6]{} \\
\hline & $p \mathrm{NP}-\alpha$-maltopentaoside & $0.36 \pm 0.06$ & $4.5 \pm 0.2$ & & & \\
\hline
\end{tabular}

${ }^{\mathrm{a}}$ Numbers in paranthesis are values from assay with DMSO 


\section{GH13_13}

Source, enzyme type, GenBank accession no.

Substrate and assay conditions

$K_{\mathrm{M}}$

$\begin{array}{ll}\boldsymbol{M}_{\mathbf{M}} & \boldsymbol{k}_{\text {cat }} \\ \mathrm{m} / \mathrm{ml} & 1 / \mathrm{s}\end{array}$

$\boldsymbol{k}_{\mathrm{cat}}$

$V_{\max }$

$\boldsymbol{k}_{\mathrm{cat}} / \boldsymbol{K}_{\mathrm{M}}$

$\mathrm{ml} /(\mathrm{mg} \mathrm{s})$

$\mathrm{pH} 5.5,37^{\circ} \mathrm{C}$

$\mathrm{mg} / \mathrm{ml}$

$61 \pm 13$

$V_{\max }$

$\begin{array}{rr}(0.16 \pm 0.02)^{\mathrm{b}} & (78 \pm 10)^{\mathrm{b}} \\ 6.9 \pm 1.0 & 15.6 \pm 1.2\end{array}$

Amylopectin

$6.9 \pm 1.0 \quad 15.6$

$\mathrm{pH} 5.0,40^{\circ} \mathrm{C} \quad \mathrm{mg} / \mathrm{ml}$
$1 / \mathrm{s}$

Pullulan

0.44

$1 / \mathrm{s}$

0.81

$6^{2}$ - $\alpha$-maltotriosyl-maltotetraose

Barley (Hordeum vulgare), PULI, AAD04189

\begin{tabular}{ll}
\hline $\mathrm{pH} 5.0,40^{\circ} \mathrm{C}$ & $\mathrm{mM}$ \\
\hline $6^{3}-\alpha$-maltosyl-maltotetraose & \\
$6^{4}-\alpha$-maltosyl-maltopentaose \\
$6^{3}-\alpha$-maltotriosyl-maltotetraose \\
$6^{3}-\alpha$-maltosyl-maltotriose \\
$\mathrm{G}_{2}-\alpha$-cyclodextrin \\
$\mathrm{G}_{2}-\beta$-cyclodextrin \\
$\mathrm{G}_{2}-\gamma$-cyclodextrin
\end{tabular}

$\mathrm{mM}$

215

$\mathrm{ml} /(\mathrm{mg} \mathrm{s})$

$(488)^{\mathrm{b}}$

Reference

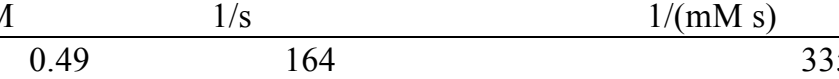

$\begin{array}{lrr}0.47 & 85 & 181\end{array}$

$\begin{array}{lll}0.78 & 218 & 279\end{array}$

$\begin{array}{rrr}3.3 & 157 & 48\end{array}$

$\begin{array}{lll}0.087 & 10 & 113\end{array}$

$\begin{array}{llr}0.47 & 5 & 11\end{array}$

\section{$\mathrm{pH} 5.0,40^{\circ} \mathrm{C}$}

0.19

$6^{3}$ - $\alpha$-maltosyl-maltotetraose

$\mathrm{mM}$

$6^{4}$ - $\alpha$-maltosyl-maltopentaose

$6^{3}$ - $\alpha$-maltotriosyl-maltotetraose

$6^{3}-\alpha$-maltosyl-maltotriose

$0.98 \quad 2071$

$\mathrm{G}_{2}-\alpha$-cyclodextrin

$\mathrm{G}_{2}-\beta$-cyclodextrin

$\mathrm{G}_{2}-\gamma$-cyclodextrin

$\mathrm{pH} 5.0,40^{\circ} \mathrm{C}$

Pullulan

1.19

0.7

1.7

0.083

1.1

0.12

Potato amylopectin

Klebsiella pneumoniae (Aerobacter aerogenes), PULI,

Sweet potato amylop

Wheat amylopectin

Maize amylopectin

Waxy maize amylopectin

Glutinous rice amylopectin

Waxy maize amylopectin, acid

treated

o. $1 / \mathrm{ml}$

$391 /(\mathrm{mM} \mathrm{s})$

205

Glutinous rice amylopectin, acid

treated

2071
893

2100

1409

750
2000

772

8

10

$241+2000$

103.3

$\mathrm{ml} /(\mathrm{mg} \mathrm{s})$

6076

Oyster glycogen

10.1
8.3

103.3
14.1

6076

$8.3 \quad 8.8$

8.8
10.3

10.3
8.6

7.6
9.9

9.9

9.1

9.0

9.4

1.1

1.4

0.9
0.9

Rabbit liver glycogen

$\begin{array}{ll}8.9 & 19.9\end{array}$

Sweet corn phytoglycogen

$\begin{array}{lr}7.7 & 13.7 \\ 33 & 4.5 \\ 20 & 1.8 \\ 50 & 8.2\end{array}$




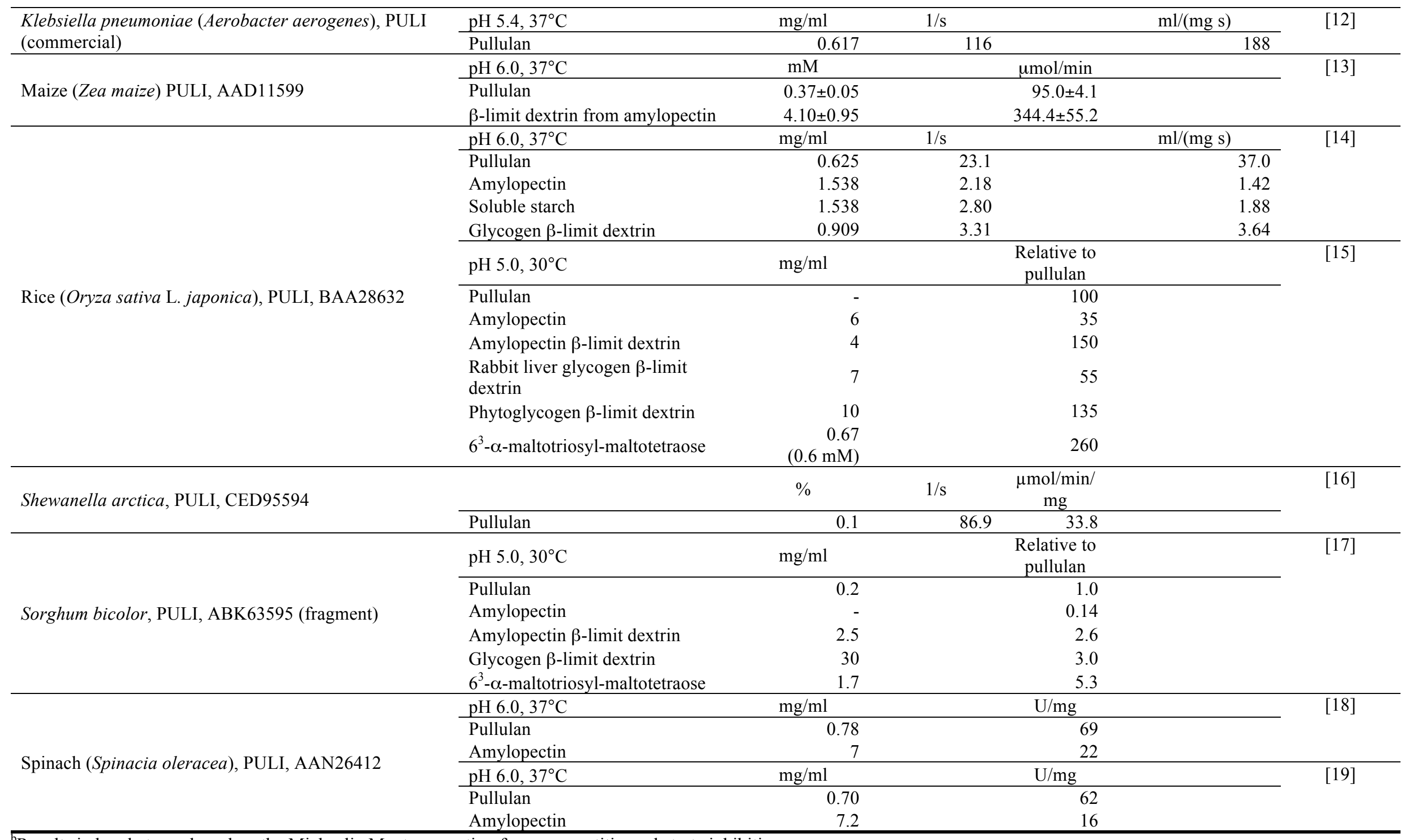

${ }^{5}$ Results in brackets are based on the Michaelis-Menten equation for uncompetitive substrate inhibition 


\section{GH13_14}

Source, enzyme type, GenBank accession no.

Substrate and assay conditions

$K_{\mathrm{M}}$

$\mathrm{pH} 8,60^{\circ} \mathrm{C}$

Pullulan

$\mathrm{mg} / \mathrm{m}$

$\boldsymbol{k}_{\text {cat }}$

$V_{\max }$
$\mathrm{U} / \mathrm{mg}$
61

$k_{\mathrm{cat}} / K_{\mathrm{M}}$

$\mathrm{U} / \mathrm{min}$

61

Pullulan

$\mathrm{mg} / \mathrm{ml}$

$\begin{array}{lr} & \mathrm{U} / \mathrm{min} \\ 4.0 & 0.23\end{array}$

Soluble starch

Dextran

$\mathrm{pH} 5.0,40^{\circ} \mathrm{C}$

11.1

$\mathrm{mM}$

Bacillus acidopullulyticus, PULI, CAC60156

$6^{3}-\alpha$-maltosyl-maltotetraose

$1 / \mathrm{s}$

1.25

6 - $\alpha$-maltosyl-maltopentaose

0.3

$6^{3}$ - $\alpha$-maltotriosyl-maltotetraose

0.47

0.23
1.5

$6^{3}$ - $\alpha$-maltosyl-maltotriose

$\mathrm{G}_{2}$ - $\alpha$-cyclodextrin

$\mathrm{G}_{2}-\beta$-cyclodextrin

$\mathrm{G}_{2}-\gamma$-cyclodextrin

0.21

$\mathrm{pH} 4.5,37^{\circ} \mathrm{C}$

1.4

0.08

Pullulan $\mathrm{mg} / \mathrm{ml}$

0.08

$1 / \mathrm{s}$

164

$\begin{array}{rr}164 & 550 \\ 61 & 130\end{array}$

87
65

8

50

31

$\mathrm{pH} 5.4,60^{\circ} \mathrm{C}$

$0.7 \pm 0.02$

$1 / \mathrm{s}$

31

$\mathrm{mg} / \mathrm{ml}$

$1900.4 \pm 103.5$

$\begin{array}{llll}\mathrm{g} / \mathrm{ml} & 1 / \mathrm{s} & \mathrm{U} / \mathrm{mg} & \mathrm{ml} /(\mathrm{mg} \mathrm{s}) \\ 0.38 \pm 0.02 & 2031 \pm 97.5 & 436 \pm 21.6 & 5403 \pm 270.1\end{array}$

Pullulan

Bacillus subtilis strain 168, PULI, AAC00283

$\mathrm{pH} 5.4,37^{\circ} \mathrm{C}$

$0.38 \pm 0.02$

Pullulan

$\mathrm{pH} 6.0,50^{\circ} \mathrm{C}$

$\mathrm{mg} / \mathrm{ml}$

Exiguobacterium acetylium a1/YH5, PULI

Pullulan

Soluble starch

$2031 \pm 97$

$5403 \pm 270.1$

\begin{tabular}{|c|c|c|c|c|c|c|}
\hline \multirow{3}{*}{ Exiguobacterium acetylium a1/YH5, PULI } & \multirow{3}{*}{ Pullulan } & & & & \\
\hline & & $0.12 \pm 0.02$ & & $33.79 \pm 0.26$ & & \\
\hline & & $0.69 \pm 0.04$ & & $20.17 \pm 0.28$ & & \\
\hline \multirow{4}{*}{ Exiguobacterium sp. SH3, PULI, AJG04842 } & $\mathrm{pH} 7.0,37^{\circ} \mathrm{C}$ & $\mathrm{mg} / \mathrm{ml}$ & & $\mathrm{U} / \mathrm{ml}$ & & [25] \\
\hline & Pullulan & 0.069 & & 967 & & \\
\hline & $\mathrm{pH} 8.5,45^{\circ} \mathrm{C}$ & $\mathrm{mg} / \mathrm{ml}$ & $1 / \mathrm{s}$ & $\mathrm{U} / \mathrm{mg}$ & $\mathrm{ml} /(\mathrm{mg} \mathrm{s})$ & {$[26]$} \\
\hline & Pullulan & 2.8 & 37 & 20.3 & 13.2 & \\
\hline \multirow{2}{*}{$\begin{array}{l}\text { Fervidobacterium pennavorans Ven5, PULI, } \\
\text { AAD } 30387\end{array}$} & $\mathrm{pH} 6.0,80^{\circ} \mathrm{C}$ & $\mathrm{mg} / \mathrm{ml}$ & & $\mathrm{U} / \mathrm{mg}$ & & [27] \\
\hline & Pullulan & 0.4 & & 1.58 & & \\
\hline \multirow{4}{*}{ Lactobacillus plantarum L137, PULII_I, BAF93906 } & $\mathrm{pH} 4.0,40^{\circ} \mathrm{C}$ & $\mathrm{mg} / \mathrm{ml}$ & $1 / \mathrm{s}$ & $\mathrm{U} / \mathrm{mg}$ & $\mathrm{ml} /(\mathrm{mg} \mathrm{s})$ & {$[28,29]$} \\
\hline & Pullulan & 6.9 & 18.0 & 37.9 & 3.3 & \\
\hline & Soluble starch & 7.7 & 25.5 & 53.4 & 5.9 & \\
\hline & Amylose & 2.6 & 15.3 & 32.3 & 2.6 & \\
\hline \multirow{2}{*}{ Paenibacillus polymyxa Nws-pp2, PULI, AIE88189 } & $\mathrm{pH} 6.0,35^{\circ} \mathrm{C}$ & $\mathrm{mg} / \mathrm{ml}$ & & $\mathrm{U} / \mathrm{mg}$ & & [30] \\
\hline & Pullulan & 15.25 & & 20.1 & & \\
\hline
\end{tabular}




\section{GH13_39}

Source, enzyme type, GenBank accession no.

Geobacillus thermoleovorans NP33, PULII_I,

AFI70750

\begin{tabular}{ll} 
Pullulan & Starch \\
\hline
\end{tabular}

\section{Substrate and assay conditions}

$\mathrm{mg} / \mathrm{m}$

$\begin{array}{ll}\boldsymbol{k}_{\text {cat }} \\ 3.3 & 1 / \mathrm{s}\end{array}$

$\boldsymbol{k}_{\mathrm{cat}}$

$V_{\max }$

$V_{\max }$

$k_{\text {cat }} / K_{\mathrm{M}}$

Reference

Thermoanaerobacter pseudethanolicus ATCC33223

(Clostricium thermohydrosulfuricum), PULII_I,

ABY95795

Starch $\mathrm{mg} / \mathrm{ml}$

\begin{tabular}{lll}
3.3 & 1941 & 640 \\
0.8 & 2021 & 666 \\
\hline
\end{tabular}

Pullulan
Amylose

$\mathrm{ml} /(\mathrm{mg} \mathrm{s})$

Thermoanaerobacterium saccharolyticum NTOU1,

PULII_I

pH $6.0,70^{\circ} \mathrm{C}$

0.35

$1 / \mathrm{s}$

1.00

\begin{tabular}{lrrr}
\hline Pullulan & \multicolumn{1}{c}{$\mathrm{mg} / \mathrm{m}$} & $\mathrm{ml} /(\mathrm{mg} \mathrm{s})$ \\
Starch & $13.0 \pm 0.4$ & $1751.3 \pm 38.0$ & 135.1 \\
$65^{\circ} \mathrm{C}$ & $7.4 \pm 0.4$ & $877.9 \pm 2.0$ & 119.0
\end{tabular}

Thermoanaerobacterium thermosulfurigenes EM1

$65^{\circ} \mathrm{C}$

$\mathrm{mg} / \mathrm{ml}$

$\mathrm{mg} / \mathrm{ml}$
$\mathrm{mg} / \mathrm{ml}$
$13.0 \pm 0$
$7.4 \pm 0$
$\mathrm{mg} / \mathrm{ml}$

$\quad 1.5$
0.70

(Clostridium thermosulfurogenes), PULII I, AAB00841

Pullulan

1.5
0.70

GH13 debranching enzymes not classified into subfamily

\section{Source, enzyme type, GenBank accession no.}

Desulfurococcus mucosus, PULII_I, AAG31033 hydrolase type III, BAD85166

Uncultured bacterium, PULII_II, AGL50935

\section{Substrate and assay conditions}

$\mathrm{pH} 5.5,80^{\circ} \mathrm{C}$

Pullulan $\mathrm{M}$

Starch

pH 5.5

Pullulan

$\mathrm{pH} 6.0$

Soluble starch

$\mathrm{pH} 4.2,90^{\circ} \mathrm{C}$

Pullulan

$\mathrm{pH} 9.0,50^{\circ} \mathrm{C}$

Pullulan

Amylose (potato)

Soluble starch

Amylopectin (potato)

Glycogen (oyster)

\begin{tabular}{|c|c|c|c|c|}
\hline$\overline{K_{M}}$ & $k_{\text {cat }}$ & $V_{\max }$ & $\overline{k_{\text {cat }} / K_{\mathrm{M}}}$ & Reference \\
\hline M & $1 / \mathrm{s}$ & & $1 /(\mathrm{M} \mathrm{s})$ & [36] \\
\hline 0.25 & 170 & & 680 & \\
\hline 5.88 & 102 & & 12.3 & \\
\hline $\mathrm{mg} / \mathrm{ml}$ & $1 / \mathrm{s}$ & $\mathrm{U} / \mathrm{mg}$ & $\mathrm{ml} /(\mathrm{mg} \mathrm{s})$ & [37] \\
\hline $0.37 \pm 0.02$ & 157.8 & $118.39 \pm 1.76$ & 424.3 & \\
\hline $\mathrm{mg} / \mathrm{ml}$ & $1 / \mathrm{s}$ & $\mathrm{U} / \mathrm{mg}$ & $\mathrm{ml} /(\mathrm{mg} \mathrm{s})$ & \\
\hline $0.36 \pm 0.05$ & 70.9 & $53.19 \pm 11.66$ & 196.9 & \\
\hline $\mathrm{mg} / \mathrm{ml}$ & & $\mathrm{U} / \mathrm{mg}$ & & [38] \\
\hline 0.2 & & 109 & & \\
\hline $\mathrm{mg} / \mathrm{ml}$ & & $\mathrm{U} / \mathrm{mg}$ & & [39] \\
\hline $1.5 \pm 0.1$ & & $306.8 \pm 5.9$ & & \\
\hline $3.6 \pm 0.2$ & & $254.3 \pm 2.7$ & & \\
\hline $4.4 \pm 0.2$ & & $230.6 \pm 4.1$ & & \\
\hline $5.1 \pm 0.4$ & & $142.5 \pm 2.9$ & & \\
\hline $9.7 \pm 0.8$ & & $58.9 \pm 2.3$ & & \\
\hline
\end{tabular}




\begin{tabular}{|c|c|c|c|c|c|c|}
\hline Source, enzyme type, GenBank accession no. & Substrate and assay conditions & $\overline{K_{M}}$ & $\boldsymbol{k}_{\mathrm{cat}}$ & $V_{\max }$ & $k_{\text {cat }} / K_{\mathrm{M}}$ & Reference \\
\hline \multirow{3}{*}{ Pyrococcus furiosus DSM 3638, PULII_I, ABA33719 } & $90^{\circ} \mathrm{C}$ & $\mathrm{mg} / \mathrm{ml}$ & & $\mathrm{U} / \mathrm{mg}$ & & \multirow[t]{3}{*}[40]{} \\
\hline & Pullulan & $0.13 \pm 0.03$ & & $156.7 \pm 9.9$ & & \\
\hline & Soluble starch & $1.17 \pm 0.15$ & & $63.9 \pm 3.0$ & & \\
\hline \multirow{15}{*}{ Staphylothermus marinus F1, PULII_I, ABN70497 } & $\mathrm{pH} 5.0,90^{\circ} \mathrm{C}$ & $\mathrm{mg} / \mathrm{ml}$ & $1 / \mathrm{s}$ & & $\mathrm{ml} /(\mathrm{mg} \mathrm{s})$ & \multirow[t]{15}{*}{ [41] } \\
\hline & Pullulan & $0.55 \pm 0.02$ & $187.55 \pm 10.76$ & & $342.34 \pm 12.10$ & \\
\hline & Amylopectin & $16.24 \pm 2.56$ & $181.45 \pm 10.19$ & & $11.38 \pm 1.31$ & \\
\hline & Amylose & $4.71 \pm 0.26$ & $39.32 \pm 1.43$ & & $8.36 \pm 0.20$ & \\
\hline & Starch & $0.54 \pm 0.07$ & $59.69 \pm 2.90$ & & $112.46 \pm 10.25$ & \\
\hline & Glycogen & $0.07 \pm 0.01$ & $1.79 \pm 0.14$ & & $26.30 \pm 1.73$ & \\
\hline & & $\mathrm{mM}$ & $1 / \mathrm{s}$ & & $1 /(\mathrm{mM} \mathrm{s})$ & \\
\hline & $\alpha-C D$ & $5.32 \pm 0.24$ & $235.22 \pm 19.30$ & & $44.23 \pm 3.15$ & \\
\hline & $\beta-C D$ & $5.72 \pm 1.53$ & $196.60 \pm 31.16$ & & $35.46 \pm 4.54$ & \\
\hline & $\gamma-\mathrm{CD}$ & $5.76 \pm 0.19$ & $445.04 \pm 5.68$ & & $77.33 \pm 2.61$ & \\
\hline & Glucosyl- $\beta-C D$ & $5.81 \pm 0.04$ & $78.07 \pm 3.93$ & & $13.45 \pm 0.71$ & \\
\hline & Maltosyl- $\beta-C D$ & $3.88 \pm 0.13$ & $241.84 \pm 5.80$ & & $62.33 \pm 1.21$ & \\
\hline & Maltotriosyl- $\beta-C D$ & $0.22 \pm 0.05$ & $77.82 \pm 13.10$ & & $361.38 \pm 26.81$ & \\
\hline & Maltotriose & $0.56 \pm 0.004$ & $12.44 \pm 0.33$ & & $223.13 \pm 11.85$ & \\
\hline & Maltopentaose & $0.11 \pm 0.024$ & $32.07 \pm 3.45$ & & $301.38 \pm 29.54$ & \\
\hline \multirow{4}{*}{$\begin{array}{l}\text { Thermococcus kodakarensis KOD1, PULII_I, } \\
\text { BAD } 85963\end{array}$} & $\mathrm{pH} 5.5,105^{\circ} \mathrm{C}$ & $\mathrm{mg} / \mathrm{ml}$ & $1 / \mathrm{s}$ & $\mathrm{U} / \mathrm{mg}$ & $\mathrm{ml} /(\mathrm{mg} \mathrm{s})$ & \multirow[t]{4}{*}[42]{} \\
\hline & Pullulan & $2.2 \pm 0.2$ & 192.3 & $92.3 \pm 1.5$ & 87.4 & \\
\hline & $\mathrm{pH} 5.0,110^{\circ} \mathrm{C}$ & $\mathrm{mg} / \mathrm{ml}$ & $1 / \mathrm{s}$ & $\mathrm{U} / \mathrm{mg}$ & $\mathrm{ml} /(\mathrm{mg} \mathrm{s})$ & \\
\hline & Starch & $1.9 \pm 0.4$ & 27.6 & $13.2 \pm 1.3$ & 14.5 & \\
\hline
\end{tabular}




\begin{tabular}{|c|c|c|c|c|c|c|}
\hline \multicolumn{7}{|l|}{ No sequence, but pullulanase activity } \\
\hline Source, enzyme type, GenBank accession no. & Substrate and assay conditions & $K_{M}$ & $\boldsymbol{k}_{\mathrm{cat}}$ & $V_{\max }$ & $\boldsymbol{k}_{\mathrm{cat}} / \boldsymbol{K}_{\mathrm{M}}$ & Reference \\
\hline \multirow{2}{*}{ Bacillus sp. AN-7, PULI } & $\mathrm{pH} 6.0,80^{\circ} \mathrm{C}$ & $\mathrm{mg} / \mathrm{ml}$ & \multicolumn{3}{|c|}{$\mathrm{U} / \mathrm{mg}$} & \multirow[t]{2}{*}{ [43] } \\
\hline & Pullulan & 1.3 & & 154 & & \\
\hline \multirow{4}{*}{ Bacillus sp. S-1, alkaline PULI } & $\mathrm{pH} 9.0,50^{\circ} \mathrm{C}$ & $\mathrm{mg} / \mathrm{ml}$ & \multicolumn{3}{|c|}{$\mathrm{mg} / \mathrm{s} / \mathrm{ml}$} & \multirow[t]{4}{*}{ [44] } \\
\hline & Pullulan & 7.92 & & 6.6 & & \\
\hline & Amylopectin & 1.63 & & 0.63 & & \\
\hline & $\alpha, \beta$-limited dextran & 3.1 & & 0.66 & & \\
\hline \multirow{5}{*}{$\begin{array}{l}\text { Bacillus flavocaldarius KP1228, PULI, BAB18516 } \\
\text { (Classified into GH13_20, but with EC no 3.2.1.41) }\end{array}$} & $\mathrm{pH} 9.0,75^{\circ} \mathrm{C}$ & (\%)-weight/volume & $1 / \mathrm{s}$ & & $\begin{array}{c}\text { volume/ } \\
(\% \text {-weight s) }\end{array}$ & \multirow[t]{5}{*}[45]{} \\
\hline & Pullulan & 1.7 & 48.5 & & 28.5 & \\
\hline & Amylopectin & 1.8 & 12.6 & & 7.0 & \\
\hline & $\beta$-limit dextrin & 1.1 & 80.0 & & 72.7 & \\
\hline & Soluble starch & 13.0 & 51.2 & & 3.9 & \\
\hline \multirow{5}{*}{ Broad bean, Vicia faba L., PULI } & $30^{\circ} \mathrm{C}$ & $\mathrm{mg} / \mathrm{ml}$ & & Relative units & & \multirow[t]{5}{*}{ [46] } \\
\hline & Amylopectin & 1.2 & & 0.1 & & \\
\hline & Amylopectin $\beta$-limit dextrin & 1 & & 0.65 & & \\
\hline & Rabbit-liver glycogen $\beta$-limit dextrin & 17 & & 0.5 & & \\
\hline & $6^{3}-\alpha$-maltotriosyl-maltotetraose & 0.18 & & - & & \\
\hline \multirow{2}{*}{ Lactococcus lactis IBB 500, PULI } & $\mathrm{pH} 4.5,45^{\circ} \mathrm{C}$ & $\mathrm{mg} / \mathrm{ml}$ & & $\mu \mathrm{M} /(\mathrm{ml} \mathrm{mg})$ & & \multirow[t]{2}{*}{ [47] } \\
\hline & Pullulan & $0.34 \pm 0.02$ & & $2.04 \pm 0.14$ & & \\
\hline \multirow{5}{*}{ Kidney bean, Phaseolus vulgaris L., ISA1/2 } & $\mathrm{pH} 6.0,30^{\circ} \mathrm{C}, 10 \mathrm{mg} / \mathrm{ml}$ & & $\begin{array}{c}\mu \mathrm{mol} / \mathrm{min} / \mathrm{mg} \\
\text { protein }\end{array}$ & & & \multirow[t]{5}{*}{ [48] } \\
\hline & Pullulan & & $0.95 \pm 0.15$ & & & \\
\hline & Amylopectin & & $14.98 \pm 0.51$ & & & \\
\hline & Glycogen & & $8.95 \pm 1.43$ & & & \\
\hline & $\beta$-limit dextrin & & $6.58 \pm 1.34$ & & & \\
\hline \multirow{7}{*}{ Oat, Avena sativa, PULI } & $\mathrm{pH} 5.0,30^{\circ} \mathrm{C}$ & $\mathrm{mg} / \mathrm{ml}$ & & $\begin{array}{l}\text { Relative to } \\
\text { pullulan }(\%)\end{array}$ & & \multirow[t]{7}{*}{ [15] } \\
\hline & Pullulan & 0.17 & & 100 & & \\
\hline & Amylopectin & 1.4 & & 26 & & \\
\hline & Amylopectin $\beta$-limit dextrin & 1.5 & & 160 & & \\
\hline & Rabbit-liver glycogen $\beta$-limit dextrin & - & & - & & \\
\hline & Phytoglycogen $\beta$-limit dextrin & - & & - & & \\
\hline & $6^{3}$ - $\alpha$-maltotriosyl-maltotetraose & $0.23(0.2 \mathrm{mM})$ & & 380 & & \\
\hline \multirow{4}{*}{ Oat, Avena sativa, PULI } & $\mathrm{pH} 5.6,30^{\circ} \mathrm{C}$ & $\mathrm{mg} / \mathrm{ml}$ & & Relative (\%) & & \multirow[t]{4}{*}{ [49] } \\
\hline & Pullulan & 0.23 & & 100 & & \\
\hline & Glutinous rice starch $\beta$-limit dextrin & 3.00 & & 71 & & \\
\hline & Glutinous rice starch & 1.00 & & 6.4 & & \\
\hline \multirow{2}{*}{$\begin{array}{l}\text { Sugar beet, Beta vulgaris var. altissima, PULI from } \\
\text { mature roots }\end{array}$} & $\mathrm{pH} 5.6,37^{\circ} \mathrm{C}$ & & & & & \multirow[t]{2}{*}[50]{} \\
\hline & Pullulan & 0.31 & & & & \\
\hline
\end{tabular}


Thermoactinomyces thalpophilus No. 15 (Laceyella sacchari), pullulanase

Amylopectin

0.36

Amylopectin $\beta$-limit dextrin

Glycogen $\beta$-limit dextrin

pH 5.6, $70^{\circ} \mathrm{C}$

Pullulan

$\alpha-1,6$-maltotriosyl-maltotriose

Corn amylopectin

Potato amylopectin

Rabbit liver glycogen

Oyster glycogen

Lintner's starch

Short-chain amylose

Potato amylose

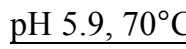

Pullulan

Amylopectin

Lintner's starch

$\mathrm{pH} 7.0,73^{\circ} \mathrm{C}$

Pullulan

$\mathrm{mg} / \mathrm{ml}$

0.45

1.11

$\mathrm{mg} / \mathrm{ml}$

0.07

$1 / \mathrm{s}$

$1 / \mathrm{s}$

$\mathrm{ml} /(\mathrm{mg} \mathrm{s})$

$6.7 \cdot 10^{4} \quad 9.6 \cdot 10^{5}$

$\begin{array}{lll}0.24 & 1.8 \cdot 10^{4} & 7.5 \cdot 10^{4} \\ 0.03 & 2.3 \cdot 10^{4} & 7.7 \cdot 10^{5}\end{array}$

$\begin{array}{lll}0.03 & 2.3 \cdot 10^{4} & 7.7 \cdot 10^{5}\end{array}$

$\begin{array}{lll}0.01 & 8.3 \cdot 10^{4} & 8.3 \cdot 10^{6}\end{array}$

$\begin{array}{lll}0.04 & 3.7 \cdot 10^{4} & 9.3 \cdot 10^{5} \\ 0.01 & 1.0 \cdot 10^{5} & 1.0 \cdot 10^{7}\end{array}$

$\begin{array}{lll}0.01 & 1.0 \cdot 10^{5} & 1.0 \cdot 10^{7}\end{array}$

$\begin{array}{lll}0.05 & 2.2 \cdot 10^{4} & 4.4 \cdot 10^{5}\end{array}$

$\begin{array}{lll}0.02 & 1.5 \cdot 10^{4} & 7.5 \cdot 10^{5}\end{array}$

$(\%)$

$0.0063 \quad \mathrm{nmol} / \mathrm{min} / \mathrm{ml}$

$0.0063 \quad 114$

0.0034

$\mathrm{mg} / \mathrm{ml}$

0.42

$\begin{array}{lr} & \mathrm{U} / \mathrm{mg} \\ 0.42 & 1.8\end{array}$

12

$1.3 \cdot 10^{6}$




\section{References}

1 Song H, Jung T, Park J, Park B, Myung PK, Boos W, Woo E and Park K (2010) Structural rationale for the short branched substrate specificity of the glycogen debranching enzyme GlgX. Proteins Struct Funct Bioinf 78(8):1847-1855

2 Van TTK, Ryu S, Lee K, Kim E and Lee S (2007) Cloning and characterization of glycogen-debranching enzyme from hyperthermophilic archaeon Sulfolobus shibatae. J Microbiol Biotechn 17(5):792-799

3 Park J, Park H, Kang H, Hong J, Cha H, Woo E, Kim J, Kim M, Boos W, Lee S and Park K (2008) Oligomeric and functional properties of a debranching enzyme (TreX) from the archaeon Sulfolobus solfataricus P2. Biocatal Biotransfor 26(1-2):76-85

4 Nguyen DHD, Park J, Shim J, Tran PL, Oktavina EF, Nguyen TLH, Lee S, Park C, Li D, Park S, Stapleton D, Lee J and Park K (2014) Reaction kinetics of substrate transglycosylation catalyzed by trex of Sulfolobus solfataricus and effects on glycogen breakdown. J Bacteriol 196(11):1941-1949

5 Ara K, Saeki K, Igarashi K, Takaiwa M, Uemura T, Hagihara H, Kawai S and Ito S (1995) Purification and characterization of an alkaline amylopullulanase with both $\alpha-1,4$ and $\alpha-1,6$ hydrolytic activity from alkalophilic Bacillus sp. KSM-1378. Biochim Biophys Acta, Gen Subj 1243(3):315-324

6 Lammerts van Bueren A, Ficko-Blean E, Pluvinage B, Hehemann J, Higgins MA, Deng L, Ogunniyi AD, Stroeher UH, El Warry N, Burke RD, Czjzek M, Paton JC, Vocadlo DJ and Boraston AB (2011) The conformation and function of a multimodular glycogen-degrading pneumococcal virulence factor. Structure 19(5):640-651

7 Vester-Christensen MB, Abou Hachem M, Naested H and Svensson B (2010) Secretory expression of functional barley limit dextrinase by Pichia pastoris using high cell-density fermentation. Protein Expr Purif 69(1):112-119

8 Møller MS, Windahl MS, Sim L, Bojstrup M, Abou Hachem M, Hindsgaul O, Palcic M, Svensson B and Henriksen A (2015) Oligosaccharide and substrate binding in the starch debranching enzyme barley limit dextrinase. J Mol Biol 427(6):1263-1277

9 Greffe L, Jensen M, Bosso C, Svensson B and Driguez H (2003) Chemoenzymatic synthesis of branched oligo- and polysaccharides as potential substrates for starch active enzymes. 4(12):1307-1311

10 Jensen MT (2002) Structure and function of barley limit dextrinase and mutational analysis of barley $\alpha$-amylase isozyme differences and interaction with branched oligosaccharides. Dissertation, University of Southern Denmark, DK-5230 Odense M

11 Yokobayashi K, Akai H, Sugimoto T, Hirao M, Sugimoto K and Harada T (1973) Comparison of kinetic parameters of Pseudomonas isoamylase and Aerobacter pullulanase. Biochim Biophys Acta 293(1):197-202

12 Malle D, Itoh T, Hashimoto W, Murata K, Utsumi S and Mikami B (2006) Overexpression, purification and preliminary X-ray analysis of pullulanase from Bacillus subtilis strain 168. Acta Crystallogr, Sect F: Struct Biol Cryst Commun 62:381-384

$13 \mathrm{Wu}$ CY, Colleoni C, Myers AM and James MG (2002) Enzymatic properties and regulation of ZPU1, the maize pullulanase-type starch debranching enzyme. Arch Biochem Biophys 406(1):21-32

14 Yamasaki Y, Nakashima S and Konno H (2008) Pullulanase from rice endosperm. Acta Biochim Pol 55(3):507-510

15 Dunn G and Manners DJ (1975) Limit dextrinases from ungerminated oats (Avena sativa L.) and ungerminated rice (Oryza sativa L.). Carbohydr Res 39(2):283293

16 Elleuche S, Qoura FM, Lorenz U, Rehn T, Brueck T and Antranikian G (2015) Cloning, expression and characterization of the recombinant cold-active type-I pullulanase from Shewanella arctica. J Mol Catal B-Enzym 116:70-77

17 Hardie DG, Manners DJ and Yellowlees D (1976) Limit dextrinase from malted sorghum (Sorghum vulgare). Carbohydr Res 50(1):75-85 
18 Ludwig I, Ziegler P and Beck E (1984) Purification and properties of spinach leaf debranching enzyme. Plant Physiol 74(4):856-861

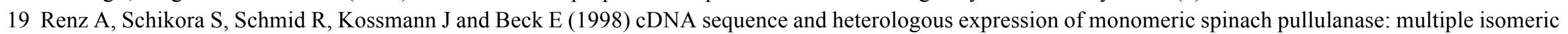
forms arise from the same polypeptide. Biochem J 331:937-945

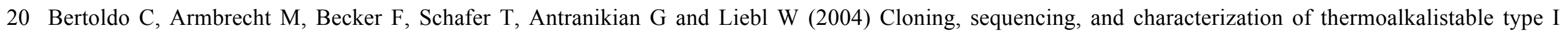
pullulanase from Anaerobranca gottschalkii. Appl Environ Microbiol 70(6):3407-3416

21 Singh RS, Saini GK and Kennedy JF (2010) Maltotriose syrup preparation from pullulan using pullulanase. Carbohydr Polym 80(2):401-407

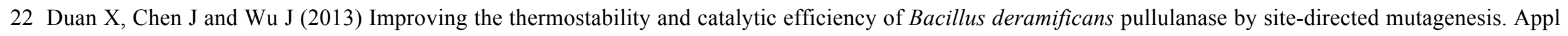
Environ Microbiol 79(13):4072-4077

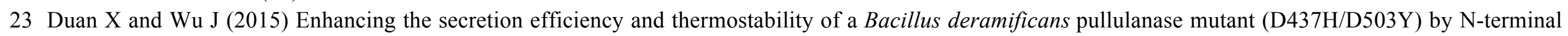
domain truncation. Appl Environ Microbiol 81(6):1926-1931

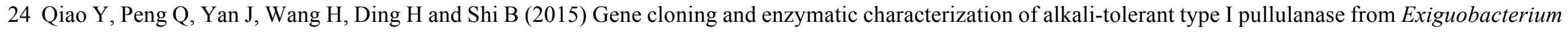
acetylicum. Lett Appl Microbiol 60(1):52-59

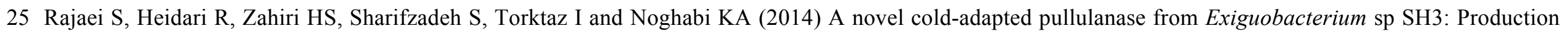
optimization, purification, and characterization. Starch-Stärke 66(3-4):225-234

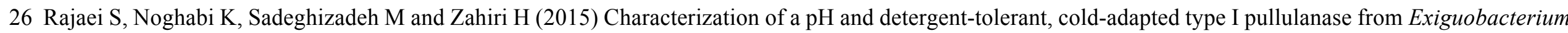
sp. SH3. Extremophiles 19(6):1145-1155

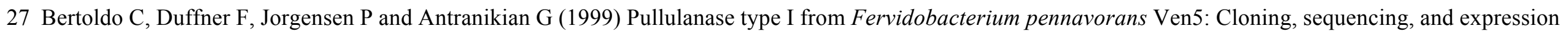
of the gene and biochemical characterization of the recombinant enzyme. Appl Environ Microbiol 65(5):2084-2091

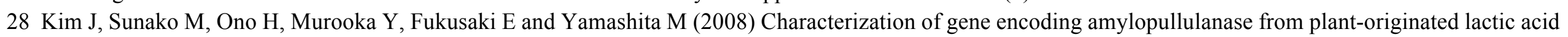
bacterium, Lactobacillus plantarum L137. J Biosci Bioeng 106(5):449-459

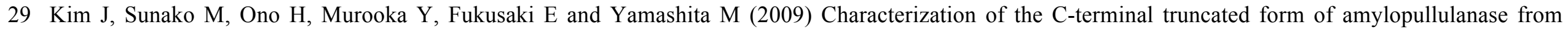
Lactobacillus plantarum L137. J Biosci Bioeng 107(2):124-129

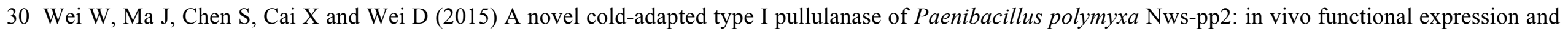
biochemical characterization of glucans hydrolyzates analysis. BMC Biotechnol 15:1-13

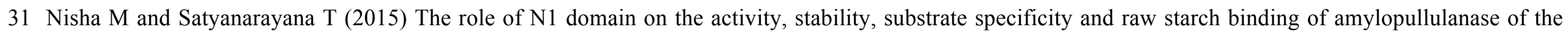
extreme thermophile Geobacillus thermoleovorans. Appl Microbiol Biotechnol 99(13):5461-5474

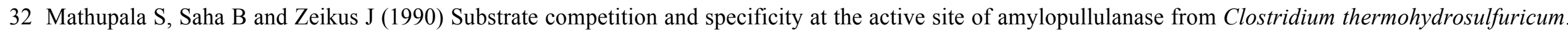
Biochem Biophys Res Commun 166(1):126-132

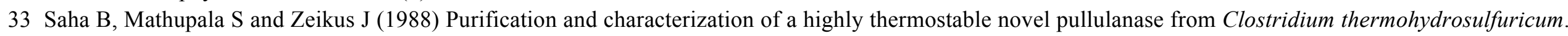
Biochem J 252(2):343-348

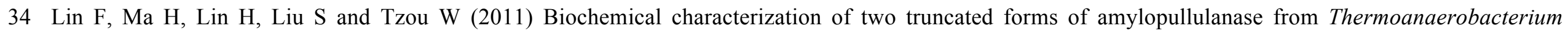
saccharolyticum NTOU1 to identify its enzymatically active region. Appl Biochem Biotechnol 165(3-4):1047-1056

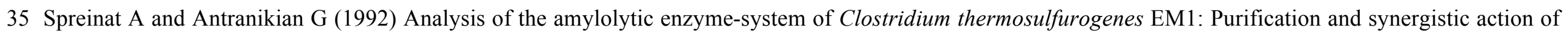
pullulanases and maltohexaose forming $\alpha$-amylase. Starch-Stärke 44(8):305-312 
36 Duffner F, Bertoldo C, Andersen J, Wagner K and Antranikian G (2000) A new thermoactive pullulanase from Desulfurococcus mucosus: Cloning, sequencing, purification, and characterization of the recombinant enzyme after expression in Bacillus subtilis. J Bacteriol 182(22):6331-6338

37 Han T, Zeng F, Li Z, Liu L, Wei M, Guan Q, Liang X, Peng Z, Liu M, Qin J, Zhang S and Jia B (2013) Biochemical characterization of a recombinant pullulanase from Thermococcus kodakarensis KOD1. Lett Appl Microbiol 57(4):336-343

38 Ahmad N, Rashid N, Haider MS, Akram M and Akhtar M (2014) Novel maltotriose-hydrolyzing thermoacidophilic type III pullulan hydrolase from Thermococcus kodakarensis. Appl Environ Microbiol 80(3):1108-1115

39 Lee YS, Seo SH, Yoon SH, Kim SY, Hahn BS, Sim JS, Koo BS and Lee CM (2016) Identification of a novel alkaline amylopullulanase from a gut metagenome of Hermetia illucens. Int J Biol Macromolec 82:514-522

40 Dong G, Vieille C and Zeikus J (1997) Cloning, sequencing, and expression of the gene encoding amylopullulanase from Pyrococcus furiosus and biochemical characterization of the recombinant enzyme. Appl Environ Microbiol 63(9):3577-3584

41 Li X, Li D and Park K (2013) An extremely thermostable amylopullulanase from Staphylothermus marinus displays both pullulan- and cyclodextrin-degrading activities. Appl Microbiol Biotechnol 97(12):5359-5369

42 Guan Q, Guo X, Han T, Wei M, Jin M, Zeng F, Liu L, Li Z, Wang Y, Cheong G, Zhang S and Jia B (2013) Cloning, purification and biochemical characterisation of an organic solvent-, detergent-, and thermo-stable amylopullulanase from Thermococcus kodakarensis KOD1. Process Biochem 48(5-6):878-884

43 Kunamneni A and Singh S (2006) Improved high thermal stability of pullulanase from a newly isolated thermophilic Bacillus sp AN-7. Enzyme Microb Technol 39(7):1399-1404

44 Kim CH, Choi HI and Lee DS (1993) Purification and biochemical properties of an alkaline pullulanase from alkalophilic Bacillus sp. S-1. Biosci Biotechnol Biochem 57(10):1632-1637

45 Suzuki Y, Hatagaki K and Oda H (1991) A hyperthermostable pullulanase produced by an extreme thermophile, Bacillus flavocaldarius Kp-1228, and evidence for the proline theory of increasing protein thermostability. Appl Microbiol Biotechnol 34(6):707-714

46 Gordon RW, Manners DJ and Stark JR (1975) Limit dextrinase of broad bean (Vicia faba L.). Carbohydr Res 42(1):125-134

47 Wasko A, Polak-Berecka M and Targonski Z (2011) Purification and characterization of pullulanase from Lactococcus lactis. Prep Biochem Biotechnol $41(3)$ :252261

48 Takashima Y, Senoura T, Yoshizaki T, Haniada S, Ito H and Matsui H (2007) Differential chain-length specificities of two isoamylase-type starch-debranching enzymes from developing seeds of kidney bean. Biosci Biotechnol Biochem 71(9):2308-2312

49 Yamada J (1981) Purification of oat debranching enzyme and occurrence of inactive debranching enzyme in cereals. Agric Biol Chem 45(4):1013-1015

50 Masuda H, Takahashi T and Sugawara S (1987) Purification and properties of starch hydrolyzing enzymes in mature roots of sugar-beets. Plant Physiol 84(2):361365

51 Odibo F and Obi S (1988) Purification and characterization of a thermostable pullulanase from Thermoactinomyces thalpophilus. J Ind Microbiol 3(6):343-350

52 Plant AR, Clemens RM, Morgan HW and Daniel RM (1987) Active-site and substrate-specificity of Thermoanaerobium Tok6-B1 pullulanase. Biochem J 246(2):537-541

53 Plant AR, Morgan HW and Daniel RM (1986) A highly stable pullulanase from Thermus aquaticus YT-1. Enzyme Microb Technol 8(11):668-672

54 Kim C, Nashiru O and Ko J (1996) Purification and biochemical characterization of pullulanase type I from Thermus caldophilus GK-24. FEMS Microbiol Lett 138(2-3):147-152 
Table S2. Relative specific activities of characterised members of GH13 subfamilies 11-14 and 39 including non-sequenced enzymes with pullulanase activity as well as GH13 pullulanase members not assigned to a subfamily, and GH57 enzymes.

\begin{tabular}{|c|c|c|c|c|}
\hline & \multicolumn{3}{|c|}{ GH13_11 } & GH13_12+44 \\
\hline $\begin{array}{l}\text { Organism, enzyme name, } \\
\text { GenBank accession no., } \\
\text { reference }\end{array}$ & $\begin{array}{l}\text { Flavobacterium } \\
\text { sp., GDE, } \\
\text { AAB63356 [1] }\end{array}$ & $\begin{array}{l}\text { Pseudomonas, } \\
\text { ISA [2] }\end{array}$ & $\begin{array}{l}\text { Sulfolobus } \\
\text { shibatae B12, } \\
\text { GDE, AAM } 81590 \\
{[3]}\end{array}$ & $\begin{array}{l}\text { Bacillus so. KSM- } \\
\text { 1378, PULII_II, } \\
\text { AAS36537 [4] }\end{array}$ \\
\hline $\begin{array}{l}\text { Assay conditions: } \mathrm{pH} \text {, } \\
\text { temperature, substrate } \\
\text { concentration }\end{array}$ & & & $\begin{array}{l}\mathrm{pH} 5.5,70^{\circ} \mathrm{C}, 1 \% \\
(\mathrm{w} / \mathrm{v})\end{array}$ & $\mathrm{pH} 9.0,50^{\circ} \mathrm{C}$ \\
\hline $\begin{array}{l}\text { Pullulan } \\
\end{array}$ & 2 & 0.5 & 36.8 & 100 \\
\hline Amylopectin & 100 (corn) & $\begin{array}{l}100 \text { (potato) } \\
106 \text { (sweet } \\
\text { potato) } \\
111 \text { (wheat) } \\
124 \text { (maize) } \\
96 \text { (waxy maize) } \\
74 \text { (glutinous rice) }\end{array}$ & 100 & 55 (potato) \\
\hline Amylopectin limit dextrin & & & & 6 (dextrin) \\
\hline Glycogen & $\begin{array}{l}101 \text { (rabbit liver), } \\
106 \text { (oyster) }\end{array}$ & $\begin{array}{l}73 \text { (oyster) } \\
50 \text { (rabbit liver) }\end{array}$ & 73.5 & \begin{tabular}{|l|}
25 (oyster), 24 \\
(bovine muscle)
\end{tabular} \\
\hline Phytoglycogen & & 105 (sweet corn) & & \\
\hline Starch & $\begin{array}{l}70 \text { (potato), } 90 \\
\text { (rice) }\end{array}$ & & 82.4 (rice) & 130 (potato) \\
\hline Amylose & & & 16.9 & $\begin{array}{l}28 \text { (potato, } \\
\mathrm{DP}=17 \text { ) }\end{array}$ \\
\hline
\end{tabular}




\begin{tabular}{|c|c|c|c|c|c|c|}
\hline \multirow[b]{2}{*}{$\begin{array}{l}\text { Organism, enzyme name, } \\
\text { GenBank accession no., } \\
\text { reference }\end{array}$} & \multicolumn{6}{|c|}{ GH13_13 } \\
\hline & $\begin{array}{l}\text { Barley (Hordeum } \\
\text { vulgare), PULI, } \\
\text { AAD04189 [5] }\end{array}$ & $\begin{array}{l}\text { Klebsiella } \\
\text { pneumoniae } \\
\text { (Aerobacter } \\
\text { aerogenes), PULI, } \\
\text { AAA25124 [2] }\end{array}$ & $\begin{array}{l}\text { Klebsiella } \\
\text { pneumoniae } \\
\text { (Aerobacter } \\
\text { aerogenes), PULI, } \\
\text { AAA25124 [6] }\end{array}$ & $\begin{array}{l}\text { Rice (Oryza } \\
\text { sativa), PULI, [7] }\end{array}$ & $\begin{array}{l}\text { Rice (Oryza } \\
\text { sativa), PULI, [8] }\end{array}$ & $\begin{array}{l}\text { Sorghum } \\
\text { bicolour, PULI, } \\
\text { ABK63595 [9] }\end{array}$ \\
\hline $\begin{array}{l}\text { Assay conditions: } \mathrm{pH}, \\
\text { temperature, substrate } \\
\text { concentration }\end{array}$ & $\begin{array}{l}\mathrm{pH} 5.2,37^{\circ} \mathrm{C}, 1 \\
\mathrm{mM}\end{array}$ & $\begin{array}{l}\mathrm{pH} 5.5,40^{\circ} \mathrm{C}, 2 \% \\
(\mathrm{w} / \mathrm{v})\end{array}$ & $\begin{array}{l}\mathrm{pH} 5.0,35^{\circ} \mathrm{C} \\
0.5 \%(\mathrm{w} / \mathrm{v})\end{array}$ & $\mathrm{pH} 5.0,30^{\circ} \mathrm{C}$ & $\mathrm{pH} 6.0,37^{\circ} \mathrm{C}$ & $\mathrm{pH} 5.0,30^{\circ} \mathrm{C}$ \\
\hline Pullulan & 100 & 100 & 100 & 100 & 100 & 100 \\
\hline Amylopectin & $<<1$ & $\begin{array}{l}9.1 \text { (potato), } 6.0 \\
\text { (sweet potato), } \\
7.2 \text { (wheat), } 5.5 \\
\text { (maize), } 6.0 \\
\text { (waxy maize), } 6.4 \\
\text { (glutinous rice), } \\
13.6 \text { (waxy maize, } \\
\text { acid-treated), } 9.4 \\
\text { (glutinous rice, } \\
\text { acid-treated) }\end{array}$ & & & 34.1 & \\
\hline Amylopectin limit dextrin & 68 & & & & $19.5(\beta-)$ & \\
\hline Glycogen & 0 & $\begin{array}{l}1.7 \text { (oyster), } 1.1 \\
\text { (rabbit liver) }\end{array}$ & & & 6.3 & \\
\hline Phytoglycogen & & 2.3 (sweet corn) & & & & \\
\hline Soluble starch & & & & & 15.8 & \\
\hline Panose & & & & 0 & & 0 \\
\hline $6^{3}-\alpha$-D-glucosyl-maltotriose & & & 0 & 0 & & \\
\hline $6^{3}-\alpha$-maltosyl-maltotriose & 13 & & 55 & 50 & & 220 \\
\hline $6^{3}-\alpha$-maltosyl-maltotetraose & 123 & & 171 & 210 & & 300 \\
\hline $6^{3}$ - $\alpha$-maltotriosyl-maltotriose & 119 & & 91 & 170 & & 250 \\
\hline $6^{3}$ - $\alpha$-maltotriosyl-maltotetraose & 243 & & 112 & 260 & & 400 \\
\hline maltosyl- $\alpha$-cyclodextrin & & & & & & 0 \\
\hline maltosyl-3-cyclodextrin & & & & & & 50 \\
\hline
\end{tabular}




\begin{tabular}{|c|c|c|c|c|}
\hline \multirow[b]{2}{*}{$\begin{array}{l}\text { Organism, enzyme name, } \\
\text { GenBank accession no., } \\
\text { reference }\end{array}$} & \multicolumn{4}{|c|}{ GH13_13, continued } \\
\hline & $\begin{array}{l}\text { Spinacia } \\
\text { oleracea, spinach, } \\
\text { PULI, AAN26412 } \\
{[10]}\end{array}$ & $\begin{array}{l}\text { Spinacia } \\
\text { oleracea, spinach, } \\
\text { recombinant } \\
\text { PULI, AAN26412 } \\
{[11]}\end{array}$ & $\begin{array}{l}\text { Zea maize, maize, } \\
\text { PULI, AAD1 } 1599 \\
{[12]}\end{array}$ & $\begin{array}{l}\text { Shewanella } \\
\text { arctica, PULI, } \\
\text { CED95594 [13] }\end{array}$ \\
\hline $\begin{array}{l}\text { Assay conditions: } \mathrm{pH}, \\
\text { temperature, substrate } \\
\text { concentration }\end{array}$ & $\mathrm{pH} 9.0,50^{\circ} \mathrm{C}$ & $\begin{array}{l}\mathrm{pH} 5.2,37^{\circ} \mathrm{C}, 1 \\
\mathrm{mM}\end{array}$ & $\begin{array}{l}\mathrm{pH} 5.5,40^{\circ} \mathrm{C}, 2 \% \\
(\mathrm{w} / \mathrm{v})\end{array}$ & $\mathrm{pH} 6.0$ \\
\hline Pullulan & 100 & 100 & 100 & 100 \\
\hline Amylopectin & 17.4 & 16 (maize) & 20 & 38.7 \\
\hline Amylopectin limit dextrin & & & 135 & \\
\hline Glycogen & $\begin{array}{l}0 \text { (oyster), } 0 \\
\text { (bovine and rabbit } \\
\text { liver) }\end{array}$ & & 0 (oyster) & \\
\hline Phytoglycogen & & & 9 & \\
\hline Soluble starch & 37 & 35 & & 47.8 \\
\hline Amylose & 0 & 0 & & 1.6 \\
\hline$\beta$-glucan & & & & 2.3 \\
\hline Birchwood xylan & & & & 1.2 \\
\hline
\end{tabular}

\begin{tabular}{|c|c|c|c|c|}
\hline \multirow[b]{2}{*}{$\begin{array}{l}\text { Organism, enzyme name, } \\
\text { GenBank accession no., } \\
\text { reference }\end{array}$} & \multicolumn{4}{|c|}{ GH13_14 } \\
\hline & $\begin{array}{l}\text { Anaerobranca } \\
\text { gottshalskii, } \\
\text { PULI, AAS47565 } \\
{[14]}\end{array}$ & $\begin{array}{l}\text { Bacillus } \\
\text { acidopullulyticus, } \\
\text { PULII, } \\
\text { CAC60156 [15] }\end{array}$ & $\begin{array}{l}\text { Exiguobacterium } \\
\text { acetylicum } \\
\text { a1/YH5, PULI, } \\
\text { AFL46505 [16] }\end{array}$ & $\begin{array}{l}\text { Paenibacilus } \\
\text { polymyxa } \text { Nws- } \\
\text { pp2, PULI, } \\
\text { AIE88189 [17] }\end{array}$ \\
\hline $\begin{array}{l}\text { Assay conditions: } \mathrm{pH}, \\
\text { temperature, substrate } \\
\text { concentration }\end{array}$ & $\begin{array}{l}\mathrm{pH} 8.0,60^{\circ} \mathrm{C}, \\
0.5 \%(0.2 \% \text { for } \\
\text { amylose })(\mathrm{w} / \mathrm{v})\end{array}$ & $\begin{array}{l}\mathrm{pH} 5.0,35^{\circ} \mathrm{C}, \\
0.5 \%(\mathrm{w} / \mathrm{v})\end{array}$ & $\begin{array}{l}\mathrm{pH} 6.0,50^{\circ} \mathrm{C}, \\
0.5 \%(\mathrm{w} / \mathrm{v})\end{array}$ & $\begin{array}{l}\mathrm{pH} 6.0,35^{\circ} \mathrm{C}, 1 \% \\
(\mathrm{w} / \mathrm{v})\end{array}$ \\
\hline Pullulan & 100 & 100 & 100 & 100 \\
\hline Amylopectin & 14 & 16 (rice) & 6.0 & 72.2 \\
\hline Amylopectin limit dextrin & $24(\beta-)$ & & $19.7(\beta-)$ & \\
\hline Glycogen & 3 & 2 (oyster) & 6.1 & 4.1 \\
\hline Glycogen $\beta$-limit dextrin & & $\begin{array}{l}26 \text { (oyster), } 32 \\
\text { (rabbit liver) }\end{array}$ & & \\
\hline Soluble starch & 15 & 10 & 12.8 & 67.8 \\
\hline \multirow[t]{2}{*}{ Amylose } & N.D. & & & \\
\hline & \multicolumn{4}{|c|}{ GH13 39} \\
\hline
\end{tabular}




\begin{tabular}{l|l|l|l}
\hline $\begin{array}{l}\text { Organism, enzyme name, } \\
\text { GenBank accession no., } \\
\text { reference }\end{array}$ & $\begin{array}{l}\text { Geobacillus } \\
\text { thermoleovorans } \\
\text { NP33, PULII_I, } \\
\text { AFI70750 [18] }\end{array}$ & $\begin{array}{l}\text { Thermoanaerobacterium } \\
\text { saccharolyticum B6A- } \\
\text { RI, PULII_, } \\
\text { AAA23205 [19] }\end{array}$ & $\begin{array}{l}\text { Clostridium } \\
\text { thermohydrosulfuricum } \\
\text { (Thermoanaerobacter } \\
\text { thermohydrosulfuricus), } \\
\text { PUL, AAA23205 [20] }\end{array}$ \\
\hline $\begin{array}{l}\text { Assay conditions: } \mathrm{pH}, \\
\text { temperature, substrate } \\
\text { concentration }\end{array}$ & & $\mathrm{pH} 6.0,65^{\circ} \mathrm{C}, 0.2 \%$ & $\mathrm{pH} 6.0,37^{\circ} \mathrm{C}$ \\
\hline Pullulan & 77 & 100 & 100 \\
\hline Amylopectin & 90 & 53 & 62 \\
\hline Glycogen & 13 & 61 & 75 (oyster) \\
\hline Glycogen $\beta$-limit dextrin & & & 77 (oyster) \\
\hline Soluble starch & 100 & 55 & 52 \\
\hline Amylose & 64 & 56 & \\
\hline
\end{tabular}

\begin{tabular}{l|l}
\hline & \multicolumn{1}{c}{ GH57 } \\
\hline $\begin{array}{l}\text { Organism, enzyme name, } \\
\text { GenBank accession no., } \\
\text { reference }\end{array}$ & $\begin{array}{l}\text { Caldivirga } \\
\text { maquilingensis } \\
\text { IC-167, PULII_I } \\
\text { ABW02197 [21] }\end{array}$ \\
\hline $\begin{array}{l}\text { Assay conditions: } \mathrm{pH}, \\
\text { temperature, substrate } \\
\text { concentration }\end{array}$ & $\mathrm{pH} 5.0,100^{\circ} \mathrm{C}$, \\
\hline Pullulan & $1 \%(\mathrm{w} / \mathrm{v})$ \\
\hline Amylopectin & 100 \\
\hline Starch & 89 \\
\hline Amylose & 86 \\
\hline$\beta$-cyclodextrin & 57 \\
\hline
\end{tabular}




\begin{tabular}{|c|c|c|c|c|c|c|}
\hline \multirow[b]{2}{*}{$\begin{array}{l}\text { Organism, enzyme name, } \\
\text { GenBank accession no., } \\
\text { reference }\end{array}$} & \multicolumn{6}{|c|}{ No sequence/not in a subfamily } \\
\hline & $\begin{array}{l}\text { Avena sativa, oat, } \\
\text { PULI [7] }\end{array}$ & $\begin{array}{l}\text { Bacillus sp. S-1, } \\
\text { PULI [22] }\end{array}$ & $\begin{array}{l}\text { Desulfurococcus } \\
\text { muscosus, PULII, } \\
\text { recombinant, [23] }\end{array}$ & $\begin{array}{l}\text { Micrococcus sp. } \\
\mathrm{Y}-1, \mathrm{PULI} \text { [24] }\end{array}$ & $\begin{array}{l}\text { Phaseolus } \\
\text { vulgaris L., } \\
\text { kidney bean, } \\
\text { ISA1/2 and ISA3 } \\
{[25]}\end{array}$ & $\begin{array}{l}\text { Pisum sativum L., } \\
\text { pea, PULI [26] }\end{array}$ \\
\hline $\begin{array}{l}\text { Assay conditions: } \mathrm{pH}, \\
\text { temperature, substrate } \\
\text { concentration }\end{array}$ & $\mathrm{pH} 5.0,30^{\circ} \mathrm{C}$ & $\begin{array}{l}\mathrm{pH} 9.0,50^{\circ} \mathrm{C}, 2 \% \\
(\mathrm{w} / \mathrm{v})\end{array}$ & $\mathrm{pH} 5.0,30^{\circ} \mathrm{C}$ & $\begin{array}{l}\mathrm{pH} 10.0,50^{\circ} \mathrm{C} \\
1 \%(\mathrm{w} / \mathrm{v})\end{array}$ & $\begin{array}{l}\mathrm{pH} 6.0,30^{\circ} \mathrm{C}, 10 \\
\mathrm{mg} / \mathrm{ml}\end{array}$ & $\mathrm{pH} 6.0,30^{\circ} \mathrm{C}$ \\
\hline Amylopectin & & 23.5 & 35 & 38 & $1577 / 456$ & 35 \\
\hline Amylopectin limit dextrin & & $\begin{array}{l}46.3(\alpha-\text { and } \beta-), \\
18.3(\beta-)\end{array}$ & & 34 & $693 / 3773(\beta-)$ & 130 \\
\hline \multicolumn{7}{|l|}{ Dextrin } \\
\hline Glycogen & & $\begin{array}{l}13.0 \text { (oyster), } 17.7 \\
\text { (liver) }\end{array}$ & 0 & 44 (oyster) & $942 / 2229$ & 0 \\
\hline Glycogen $\beta$-limit dextrin & & & & & & 15 \\
\hline Soluble starch & & 8.6 & & 64 & & \\
\hline Amylose & & N.D. & 77 & 62 & & \\
\hline Dextran & & N.D. & 0 & & & \\
\hline $6^{3}$ - $\alpha$-maltosyl-maltotriose & 120 & & & & & 90 \\
\hline $6^{3}$ - $\alpha$-maltosyl-maltotetraose & 290 & & & & & 230 \\
\hline $6^{3}$ - $\alpha$-maltotriosyl-maltotriose & 220 & & & & & 170 \\
\hline $6^{3}-\alpha$-maltotriosyl-maltotetraose & 380 & & & & & 280 \\
\hline \multicolumn{7}{|l|}{$\alpha$-cyclodextrin } \\
\hline \multicolumn{7}{|l|}{$\beta$-cyclodextrin } \\
\hline$\gamma$-cyclodextrin & & & & & & \\
\hline
\end{tabular}




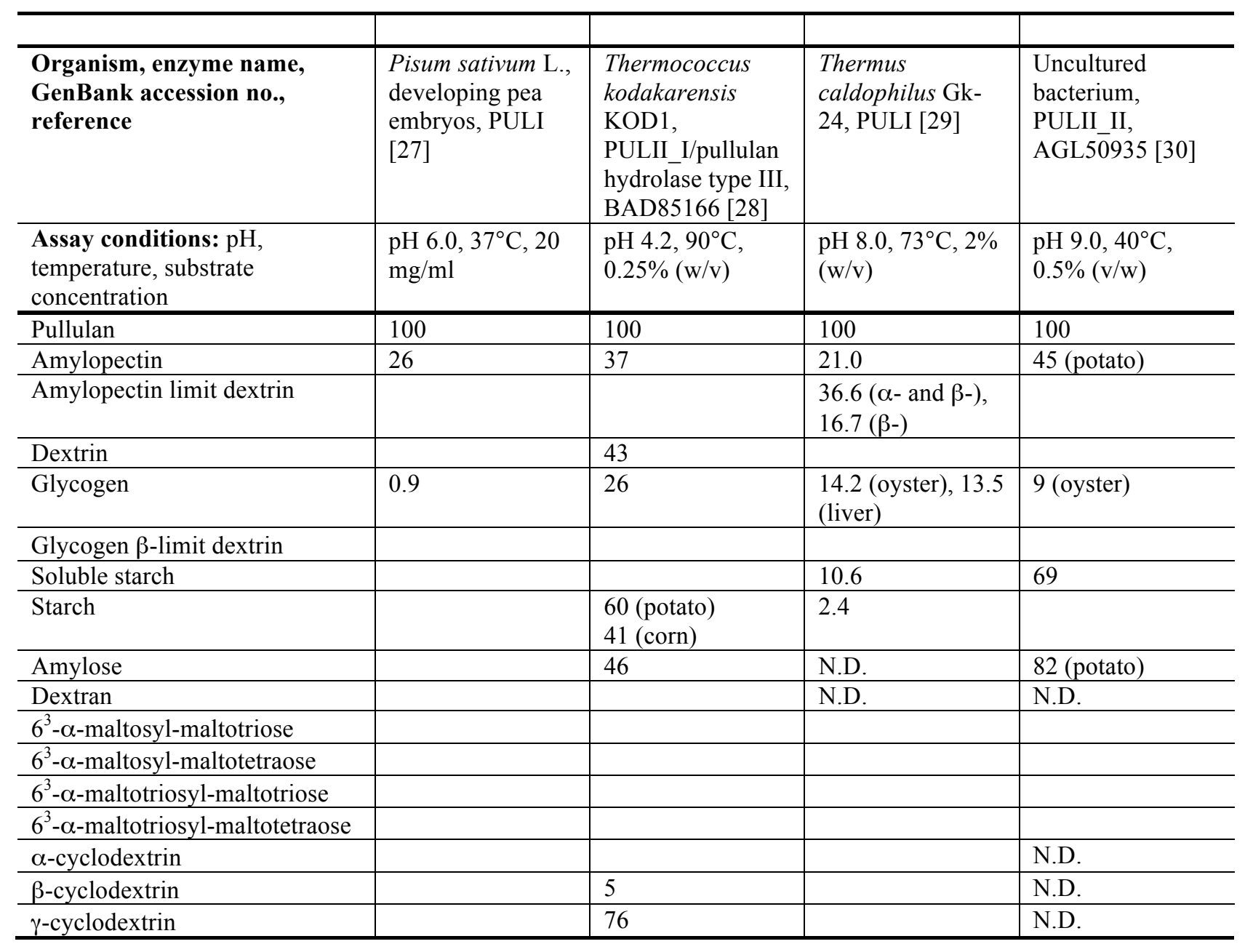




\section{References}

1 Krohn B, Barry G and Kishore G (1997) An isoamylase with neutral pH optimum from a Flavobacterium species: Cloning, characterization and expression of the iam gene. Mol Gen Genet 254(5):469-478

2 Yokobayashi K, Akai H, Sugimoto T, Hirao M, Sugimoto K and Harada T (1973) Comparison of kinetic parameters of Pseudomonas isoamylase and Aerobacter pullulanase. Biochim Biophys Acta 293(1):197-202

3 Van TTK, Ryu S, Lee K, Kim E and Lee S (2007) Cloning and characterization of glycogen-debranching enzyme from hyperthermophilic archaeon Sulfolobus shibatae. J Microbiol Biotechn 17(5):792-799

4 Ara K, Saeki K, Igarashi K, Takaiwa M, Uemura T, Hagihara H, Kawai S and Ito S (1995) Purification and characterization of an alkaline amylopullulanase with both $\alpha-1,4$ and $\alpha-1,6$ hydrolytic activity from alkalophilic Bacillus sp. KSM-1378. Biochim Biophys Acta, Gen Subj 1243(3):315-324

5 Manners DJ and Yellowlees D (1971) Studies on carbohydrate metabolising enzymes. Part XXVI. Limit dextrinase from germinated barley. Starke 23(7):228-234

6 Abdullah M, Catley BJ, Lee EYC, Robyt J, Wallenfe.K and Whelan WJ (1966) Mechanism of carbohydrase action.11. Pullulanase an enzyme specific for hydrolysis of $\alpha$-1,6-bonds in amylaceous oligo- and polysaccharides. Cereal Chem 43(1):111-118

7 Dunn G and Manners DJ (1975) Limit dextrinases from ungerminated oats (Avena sativa L.) and ungerminated rice (Oryza sativa L.). Carbohydr Res 39(2):283293

8 Yamasaki Y, Nakashima S and Konno H (2008) Pullulanase from rice endosperm. Acta Biochim Pol 55(3):507-510

9 Hardie DG, Manners DJ and Yellowlees D (1976) Limit dextrinase from malted sorghum (Sorghum vulgare). Carbohydr Res 50(1):75-85

10 Ludwig I, Ziegler P and Beck E (1984) Purification and properties of spinach leaf debranching enzyme. Plant Physiol 74(4):856-861

11 Renz A, Schikora S, Schmid R, Kossmann J and Beck E (1998) cDNA sequence and heterologous expression of monomeric spinach pullulanase: multiple isomeric forms arise from the same polypeptide. Biochem J 331:937-945

$12 \mathrm{Wu}$ CY, Colleoni C, Myers AM and James MG (2002) Enzymatic properties and regulation of ZPU1, the maize pullulanase-type starch debranching enzyme. Arch Biochem Biophys 406(1):21-32

13 Elleuche S, Qoura FM, Lorenz U, Rehn T, Brueck T and Antranikian G (2015) Cloning, expression and characterization of the recombinant cold-active type-I pullulanase from Shewanella arctica. J Mol Catal B-Enzym 116:70-77

14 Bertoldo C, Armbrecht M, Becker F, Schafer T, Antranikian G and Liebl W (2004) Cloning, sequencing, and characterization of thermoalkalistable type I pullulanase from Anaerobranca gottschalkii. Appl Environ Microbiol 70(6):3407-3416

15 Kusano S, Nagahata N, Takahashi S, Fujimoto D and Sakano Y (1988) Purification and properties of Bacillus acidopullulyticus pullulanase. Agric Biol Chem 52(9):2293-2298

16 Qiao Y, Peng Q, Yan J, Wang H, Ding H and Shi B (2015) Gene cloning and enzymatic characterization of alkali-tolerant type I pullulanase from Exiguobacterium acetylicum. Lett Appl Microbiol 60(1):52-59

17 Wei W, Ma J, Chen S, Cai X and Wei D (2015) A novel cold-adapted type I pullulanase of Paenibacillus polymyxa Nws-pp2: in vivo functional expression and biochemical characterization of glucans hydrolyzates analysis. BMC Biotechnol 15:1-13 


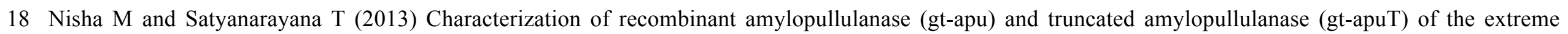
thermophile Geobacillus thermoleovorans NP33 and their action in starch saccharification. Appl Microbiol Biotechnol 97(14):6279-6292

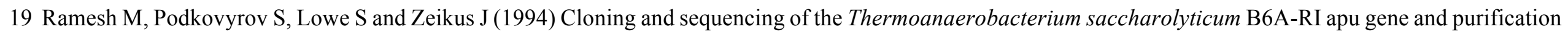
and characterization of the amylopullulanase from Escherichia coli. Appl Environ Microbiol 60(1):94-101

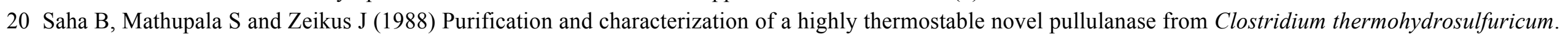
Biochem J 252(2):343-348

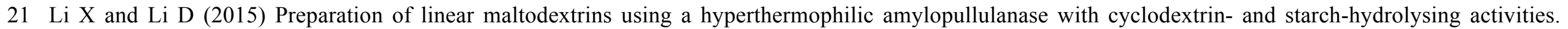
Carbohydr Polym 119:134-141

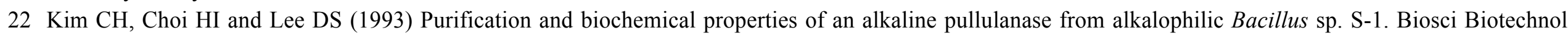
Biochem 57(10):1632-1637

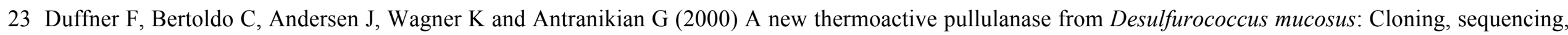
purification, and characterization of the recombinant enzyme after expression in Bacillus subtilis. J Bacteriol 182(22):6331-6338

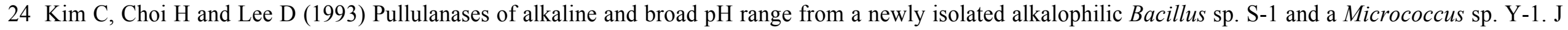
Ind Microbiol 12(1):48-57

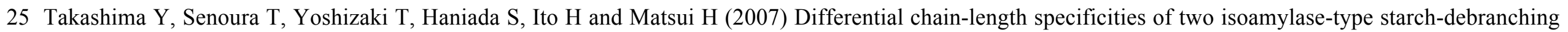
enzymes from developing seeds of kidney bean. Biosci Biotechnol Biochem 71(9):2308-2312

26 Yellowlees D (1980) Purification and characterization of limit dextrinase from Pisum sativum L. Carbohydr Res 83(1):109-118

27 Zhu Z, Hylton C, Rössner U and Smith A (1998) Characterization of starch-debranching enzymes in pea embryos. Plant Physiol 118(2):581-590

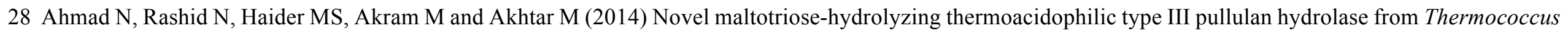
kodakarensis. Appl Environ Microbiol 80(3):1108-1115

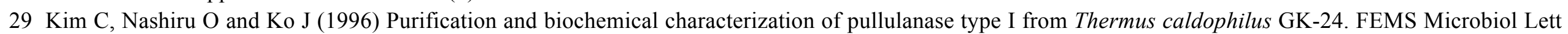
138(2-3):147-152

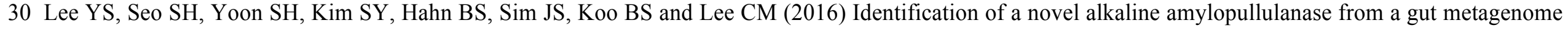
of Hermetia illucens. Int J Biol Macromolec 82:514-522 